Prepared in cooperation with the City of Durham

\title{
Water-Quality Characteristics, Trends, and Nutrient and Sediment Loads of Streams in the Treyburn Development Area, North Carolina, 1988-2009
}

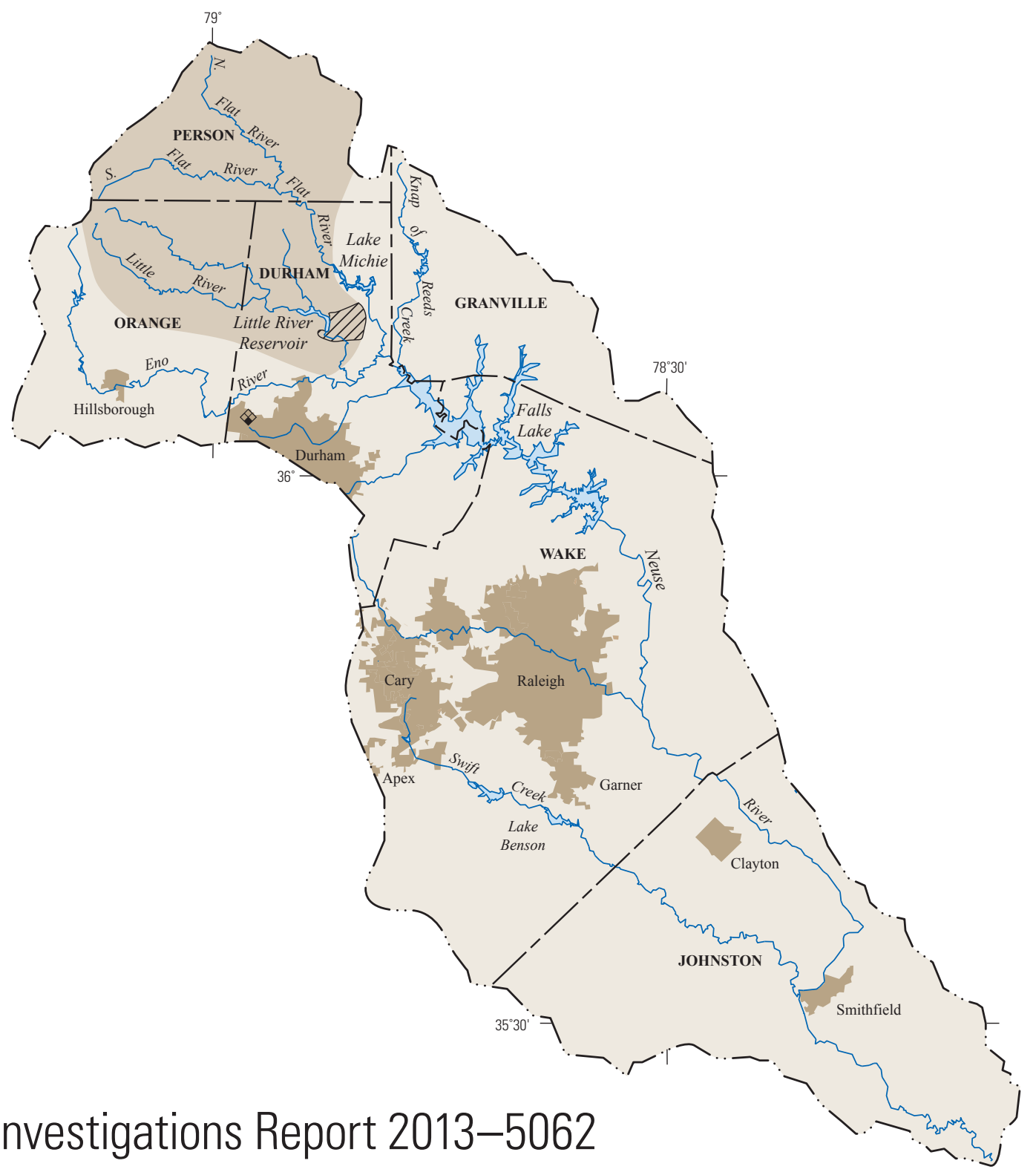

Scientific Investigations Report 2013-5062 
Cover: Map showing location of the Treyburn development and study area in the upper Neuse River Basin, North Carolina. 


\section{Water-Quality Characteristics, Trends, and Nutrient and Sediment Loads of Streams in the Treyburn Development Area, North Carolina, 1988-2009}

By Jason M. Fine, Douglas A. Harned, and Carolyn J. Oblinger

Prepared in cooperation with the City of Durham

Scientific Investigations Report 2013-5062 


\title{
U.S. Department of the Interior \\ KEN SALAZAR, Secretary
}

\author{
U.S. Geological Survey \\ Suzette M. Kimball, Acting Director
}

\section{U.S. Geological Survey, Reston, Virginia: 2013}

For more information on the USGS - the Federal source for science about the Earth, its natural and living resources, natural hazards, and the environment, visit http://www.usgs.gov or call 1-888-ASK-USGS.

For an overview of USGS information products, including maps, imagery, and publications, visit $h t t p: / / w w w . u s g s . g o v / p u b p r o d$

To order this and other USGS information products, visit http://store.usgs.gov

Any use of trade, product, or firm names is for descriptive purposes only and does not imply endorsement by the U.S. Government.

Although this report is in the public domain, permission must be secured from the individual copyright owners to reproduce any copyrighted materials contained within this report.

Suggested citation:

Fine, J.M., Harned, D.A., and Oblinger, C.J., 2013, Water-quality characteristics, trends, and nutrient and sediment loads of streams in the Treyburn development area, North Carolina, 1988-2009: U.S. Geological Survey Scientific Investigations Report 2013-5062, 59 p. 


\section{Contents}

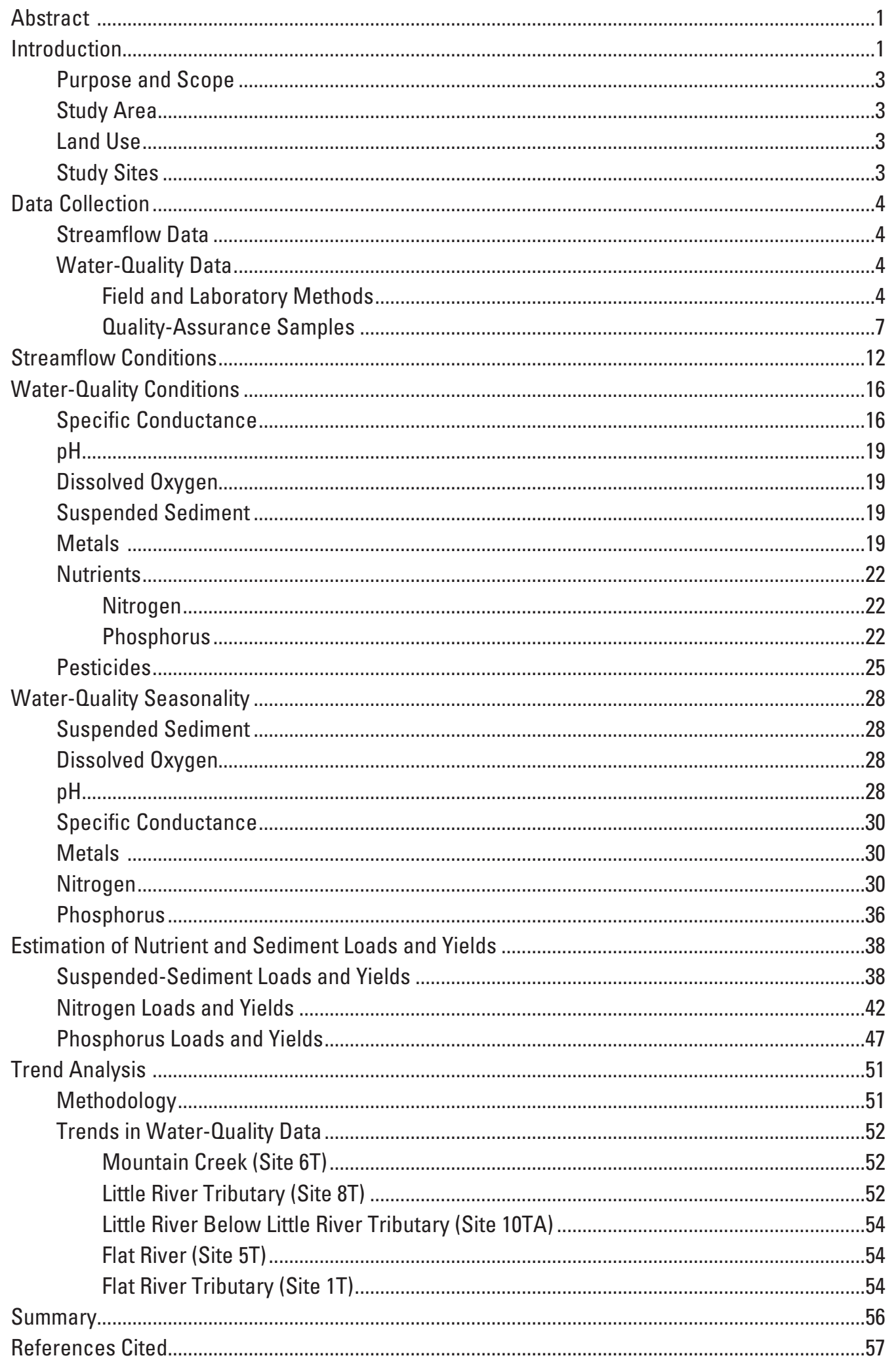




\section{Figures}

1. Map showing location of the Treyburn development and study area in the upper Neuse River Basin, North Carolina...

2. Map showing location of study sites in the vicinity of the Treyburn development area of North Carolina

3. Graphs showing mean monthly streamflow for water years 1989-93; 1994-98; 1999-2003; 2004-09, and long-term mean monthly streamflow (1925-2009) at Flat River(site 5T), North Carolina

4. Graph showing annual rainfall amounts (1988-2009) and long-term mean annual rainfall (1980-2009) measured at the National Oceanic and Atmospheric

Administration site in Durham County, North Carolina

5. Graph showing instantaneous discharge measurements at Flat River tributary (site 1T) and Little River tributary (site 8T) in the vicinity of the Treyburn development study area, North Carolina, 1994-2009.

6. Graphs showing discharge at the Little River below Little River tributary (site 10TA), Flat River (site 5T), Mountain Creek (site 6T), and Flat River tributary (site 1T) sites in the vicinity of the Treyburn development study area, North Carolina..

7. Boxplots showing variability in concentrations of dissolved-oxygen concentrations; $\mathrm{pH}$; specific conductance; and suspended-sediment concentrations for selected sites in the vicinity of the Treyburn development study area, North Carolina, 1988-2009

8. Boxplots showing variability in concentrations of dissolved ammonia; dissolved nitrite plus nitrate; total ammonia plus organic nitrogen; and total nitrogen for selected sites in the vicinity of the Treyburn development study area, North Carolina, 1988-2009.

9. Boxplots showing variability in concentrations of dissolved orthophosphate, and total phosphorus for selected sites in the vicinity of the Treyburn development study area, North Carolina, 1988-2009.

10. Boxplot showing monthly suspended-sediment concentrations for Little River (site 4T) in the vicinity of the Treyburn development study area, North Carolina, 1988-2009

11. Boxplot showing monthly dissolved-oxygen concentrations for Flat River tributary (site 1T) in the vicinity of the Treyburn development study area, North Carolina, 1988-2009

12. Boxplot showing monthly $\mathrm{pH}$ for Flat River tributary (site $1 \mathrm{~T}$ ) in the vicinity of the Treyburn development study area, North Carolina, 1988-2009

13. Boxplot showing monthly specific conductance for Little River tributary (site 8T), North Carolina, 1994-2009.

14. Boxplots showing monthly dissolved nitrate nitrogen for Little River below Little River tributary (site 10TA), 1994-2009; Flat River (site 5T), 1988-2009; Mountain Creek (site 6T), 1988-2009; and Little River tributary (site 8T), 1994-2009, in the Treyburn development study area, North Carolina.

15. Boxplots showing monthly dissolved ammonia nitrogen for Little River tributary (site 8T), 1994-2009, and Little River below Little River tributary (site 10TA), 1995-2009, in the vicinity of the Treyburn development study area, North Carolina ......33

16. Boxplots showing monthly total ammonia plus organic nitrogen for Little River (site 4T), 1988-2009; Little River tributary (site 8T), 1994-2009; Little River below Little River tributary (site 10TA), 1995-2009; and Flat River (site 5T), 1988-2009, in the vicinity of the Treyburn development study area, North Carolina. 
17. Boxplots showing monthly total nitrogen for Little River (site 4T), 1988-2009; Mountain Creek (site 6T),1994-2009; Little River below Little River tributary (site 10TA), 1995-2009; and Flat River (site 5T), 1988-2009, in the vicinity of the Treyburn development study area, North Carolina.....

18. Boxplots showing monthly dissolved orthophosphate for Little River (site 4T), 1988-2009, and Little River tributary (site 8T), 1994-2009, in the vicinity of the Treyburn development study area, North Carolina...

19. Boxplots showing monthly total phosphorus for Little River (site 4T), 1988-2009; Little River tributary (site 8T), 1994-2009; Little River below Little River tributary (site 10TA), 1995-2009; and Flat River tributary (site 1T), 1988-2009, in the vicinity of the Treyburn development study area, North Carolina ..

20. Graph showing annual suspended-sediment yields for sites in the vicinity of the Treyburn development study area, North Carolina..

21. Graph showing annual total nitrogen yields for sites in the vicinity of the Treyburn development study area, North Carolina...

22. Graph showing annual total phosphorus yields for sites in the vicinity of the Treyburn development study area, North Carolina.....

23. Graph showing total nitrogen concentrations with LOESS smooth trend line for Mountain Creek (site 6T), 1988-2009, in the vicinity of the Treyburn development study area, North Carolina

24. Graph showing suspended-sediment concentrations with LOESS smooth trend line for Mountain Creek (site 6T), 1988-2009, in the vicinity of the Treyburn development study area, North Carolina.....

25. Graph showing specific conductance with LOESS smooth trend line for Little River tributary (site 8T), 1994-2009, in the vicinity of the Treyburn development study area, North Carolina

26. Graph showing dissolved nitrate concentration with LOESS smooth trend line for Little River below Little River tributary (site 10TA), 1996-2009, in the vicinity of the Treyburn development study area, North Carolina..

27. Graph showing dissolved nitrite plus nitrate concentration with LOESS smooth trend line for Little River below Little River tributary (site 10TA), 1996-2009, in the vicinity of the Treyburn development study area, North Carolina...

28. Graph showing total ammonia plus organic nitrogen concentration with LOESS smooth trend line for Little River below Little River tributary (site 10TA), 1996-2009, in the vicinity of the Treyburn development study area, North Carolina..

30. Graph showing dissolved nitrite plus nitrate concentration with LOESS smooth trend line for Flat River (site 5T), 1994-2009, in the vicinity of the Treyburn development study area, North Carolina

29. Graph showing total nitrogen concentration with LOESS smooth trend line for Little River below Little River tributary (site 10TA), 1996-2009, in the vicinity of the Treyburn development study area, North Carolina..

31. Graph showing total ammonia plus organic nitrogen concentration with LOESS smooth trend line for Flat River (site 5T), 1988-2009, in the vicinity of the Treyburn development study area, North Carolina

32. Graph showing suspended-sediment concentration with LOESS smooth trend line for Flat River (site 5T), 1988-2009, in the vicinity of the Treyburn development study area, North Carolina

33. Graph showing specific conductance with LOESS smooth trend line for Flat River tributary (site 1T), 1988-2009, in the vicinity of the Treyburn development study area, North Carolina. 


\section{Tables}

1. Data-collection sites in the vicinity of the Treyburn development study area, North Carolina .

2. Concentrations of nutrients in replicate and blank quality-assurance samples collected in the vicinity of the Treyburn development study area, North Carolina...........8

3. Concentrations of metals in replicate and blank quality-assurance samples collected in the vicinity of the Treyburn development study area, North Carolina

4. Summary statistics for physical properties and suspended sediment collected at six sites in the vicinity of the Treyburn development study area, North Carolina, 1988-2009

5. Summary statistics for metals and minor elements collected at six sites in the vicinity of the Treyburn development study area, North Carolina, 1988-2009

6. Summary statistics for nutrients detected in stream samples collected at six sites in the vicinity of the Treyburn development study area, 1988-2009.

7. Organic compounds analyzed by the U.S. Geological Survey National Water Quality Laboratory for the Treyburn development project, North Carolina..

8. Concentrations of pesticides that exceed the laboratory reporting level in samples collected at three sites in the vicinity of the Treyburn development study area, North Carolina, 1988-2009.

9. Summary of significant variables and regression coefficients used to develop the predictive equations of loads for sites in the vicinity of the Treyburn development study area, North Carolina

10. Estimated annual suspended-sediment loads and yields for water years 1987-2009 at sites in the vicinity of the Treyburn development study area, North Carolina, including mean and median load and yield for period of record

11. Estimated annual nitrate plus nitrite loads and yields for water years 1987-2009 at sites in the vicinity of the Treyburn development study area, North Carolina, including mean and median load and yield for period of record

12. Estimated annual ammonia nitrogen loads and yields for water years 1987-2009 at sites in the vicinity of the Treyburn development study area, North Carolina, including mean and median load and yield for period of record

13. Estimated annual total ammonia plus organic nitrogen loads and yields for water years 1987-2009 at sites in the vicinity of the Treyburn development study area, North Carolina, including mean and median load and yield for period of record

14. Estimated annual total nitrogen loads and yields for water years 1987-2009 at sites in the vicinity of the Treyburn development study area, North Carolina, including mean and median load and yield for period of record

15. Estimated annual dissolved orthophosphorus loads and yields for water years 1987-2009 at sites in the vicinity of the Treyburn development study area

16. Estimated annual dissolved phosphorus loads and yields for water years 1987-2009 at sites in the vicinity of the Treyburn development study area, North Carolina, including mean and median load and yield for period of record

17. Estimated annual total phosphorus loads and yields for water years 1987-2009 at sites in the vicinity of the Treyburn development study area, North Carolina, including mean and median load and yield for period of record 


\title{
Conversion Factors
}

Inch/Pound to SI

\begin{tabular}{lll}
\hline \multicolumn{1}{c}{ Multiply } & By & \multicolumn{1}{c}{ To obtain } \\
\hline inch (in.) & Length & \\
foot (ft) & 2.54 & centimeter $(\mathrm{cm})$ \\
mile (mi) & 0.3048 & meter $(\mathrm{m})$ \\
\hline & 1.609 & kilometer $(\mathrm{km})$ \\
\hline acre & Area & \\
square mile $\left(\mathrm{mi}^{2}\right)$ & 0.4047 & hectare $(\mathrm{ha})$ \\
\hline & 2.590 & square kilometer $\left(\mathrm{km}^{2}\right)$ \\
\hline cubic foot per second per & Flow rate & \\
square mile $\left[\left(\mathrm{ft}{ }^{3} / \mathrm{s}\right) / \mathrm{mi}^{2}\right]$ & 0.01093 & cubic meter per second per \\
inch per year $(\mathrm{in} / \mathrm{yr})$ & & square $\mathrm{kilometer}\left[\left(\mathrm{m}^{3} / \mathrm{s}\right) / \mathrm{km}^{2}\right]$ \\
& 2.54 & centimeter per year $\left(\mathrm{cm}^{2} / \mathrm{yr}\right)$ \\
\hline ton, short $(2,000 \mathrm{pounds})$ & Mass & \\
ton per square mile (ton $\left./ \mathrm{mi}^{2}\right)$ & 0.9072 & megagram $(\mathrm{Mg})$ \\
\hline
\end{tabular}

Temperature in degrees Fahrenheit $\left({ }^{\circ} \mathrm{F}\right)$ may be converted to degrees Celsius $\left({ }^{\circ} \mathrm{C}\right)$ as follows:

${ }^{\circ} \mathrm{C}=\left({ }^{\circ} \mathrm{F}-32\right) / 1.8$

\section{Abbreviations}

\author{
DENR Department of Environment and Natural Resources \\ LOESS locally weighted scatterplot smoothing \\ NSW nutrient-sensitive waters \\ USGS U.S. Geological Survey \\ $\mathrm{mg} / \mathrm{L} \quad$ milligram per liter \\ $\mu \mathrm{g} / \mathrm{L} \quad$ microgram per liter
}

$\mu \mathrm{S} / \mathrm{cm}$ at $25^{\circ} \mathrm{C} \quad$ microseimen per centimeter at 25 degrees Celsius 



\title{
Water-Quality Characteristics, Trends, and Nutrient and Sediment Loads of Streams in the Treyburn Development Area, North Carolina, 1988-2009
}

\author{
By Jason M. Fine, Douglas A. Harned, and Carolyn J. Oblinger
}

\section{Abstract}

Streamflow and water-quality data, including concentrations of nutrients, metals, and pesticides, were collected from October 1988 through September 2009 at six sites in the Treyburn development study area. A review of water-quality data for streams in and near a 5,400-acre planned, mixed-use development in the Falls Lake watershed in the upper Neuse River Basin of North Carolina indicated only small-scale changes in water quality since the previous assessment of data collected from 1988 to 1998 . Loads and yields were estimated for sediment and nutrients, and temporal trends were assessed for specific conductance, $\mathrm{pH}$, and concentrations of dissolved oxygen, suspended sediment, and nutrients.

Water-quality conditions for the Little River tributary and Mountain Creek may reflect development within these basins. The nitrogen and phosphorus concentrations at the Treyburn sites are low compared to sites nationally. The herbicides atrazine, metolachlor, prometon, and simazine were detected frequently at Mountain Creek and Little River tributary but concentrations are low compared to sites nationally.

Little River tributary had the lowest median suspendedsediment yield over the 1988-2009 study period, whereas Flat River tributary had the largest median yield. The yields estimated for suspended sediment and nutrients were low compared to yields estimated for other basins in the Southeastern United States.

Recent increasing trends were detected in total nitrogen concentration and suspended-sediment concentrations for Mountain Creek, and an increasing trend was detected in specific conductance for Little River tributary. Decreasing trends were detected in dissolved nitrite plus nitrate nitrogen, total ammonia plus organic nitrogen, sediment, and specific conductance for Flat River tributary.

Water chemical concentrations, loads, yields, and trends for the Treyburn study sites reflect some effects of upstream development. These measures of water quality are generally low, however, compared to regional and national averages.

\section{Introduction}

The Treyburn development is a 5,400-acre planned, mixed-use development located in the Falls Lake watershed in the upper Neuse River Basin of North Carolina (fig. 1). The development began in 1986 and consists of residential, industrial, and recreational facilities. Development occupied 0.71 percent of the land area of the watershed in 1986 and increased to 1.12 percent by 2005 . The remainder of the land in the Treyburn development area is forest and farmland.

Three water-supply reservoirs lie just outside the Treyburn development boundaries-Lake Michie to the north, Falls Lake to the southeast, and Little River Reservoir to the west (fig. 1). Lake Michie and Little River are water supplies for Durham, and Falls Lake supplies water for Raleigh. Most of the streams in the Treyburn area are classified as WS-IV, which means they are in moderately to highly developed water-supply watersheds (North Carolina Department of Environment and Natural Resources, 2009). Much of the Treyburn development area also is classified as a water-quality critical area. A "critical area" is defined as a 0.5-mile- (mi) wide area extending from the normal pool elevation of a water-supply reservoir or from a water-supply intake on a river (North Carolina Department of Environment, Health, and Natural Resources, 1993). The WS-IV stream classification requires a 50-foot- (ft) wide buffer area on each side of perennial streams (North Carolina Division of Water Quality, 2011. In addition, no new landfills are allowed within the critical area, no new landfills can be located outside the critical area, no new sludge or petroleum-contaminated soils can be applied in the critical area, and a hazardous-material containment plan and structure(s) are required for new industries in the area. In the Treyburn development area, residential lots of 1 acre are allowed within the critical area, and 0.5-acre lots are allowed outside of the critical area. The North Carolina Division of Water Quality of the Department of Environment and Natural Resources (DENR) lists the control of urban stormwater and protection of reservoirs among the priority issues for this part 


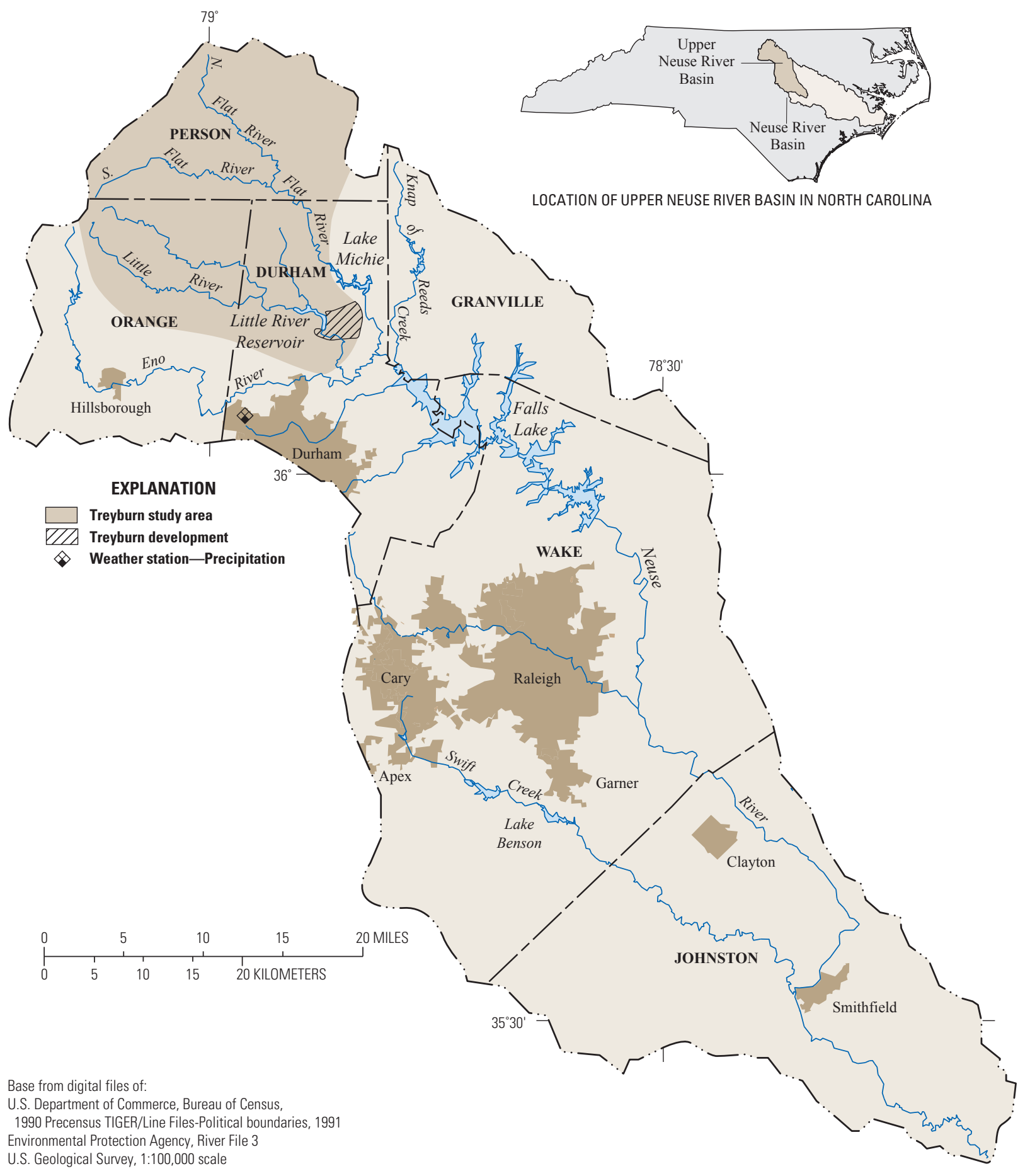

Figure 1. Location of the Treyburn development and study area in the upper Neuse River Basin, North Carolina. 
of the upper Neuse River Basin (North Carolina Department of Environment and Natural Resources, 2009). All streams in the upper Neuse watershed are classified as nutrient-sensitive waters (NSW) and are subject to special nutrient management (North Carolina Department of Environment and Natural Resources, 2009).

The Treyburn development was designed to minimize adverse effects on water quality. Because of the size of the development and its proximity to the water-supply reservoirs, however, local resource managers need to be able to quantify the effects of ongoing land-use conversion on water quality. In response to this need, the U.S. Geological Survey (USGS), in cooperation with the city of Durham, began a study in February 1988 to determine water-quality characteristics of surface waters in and around the Treyburn area. Assessing water quality at a range of watershed scales and assisting local governments are among the primary activities that have been identified to meet the USGS mission (U.S. Geological Survey, 2007).

Two previously published reports documented and analyzed hydrologic data collected in the Treyburn area. Garrett and Bales (1995) described the data collected at 17 sites that were monitored for all or part of February 1988 through September 1993. Oblinger and others (2002) discussed the collection and analysis of hydrologic and macroinvertebrate data that were collected by the USGS from July 1994 through September 1998 at six sites in the Treyburn area.

\section{Purpose and Scope}

The purpose of this report is to summarize water-quality concentration, loads, and trends of selected stream sites flowing in or near the Treyburn development. The extent to which land-use conversion has affected water quality at these sites also is described. Data used to characterize water quality, seasonality, trends, and loads were collected from October 1988 through September 2009.

\section{Study Area}

The Treyburn development is located 12 mi north of the city of Durham in the Falls Lake watershed (fig. 1). Durham and Raleigh are the principal municipalities in the area. The combined population of these cities increased 33 percent between 2000 and 2009 to about 618,000 (North Carolina Office of State Budget, Planning and Management, 2009).

Three water-supply reservoirs lie just outside the Treyburn development boundary (fig. 1). Lake Michie and the Little River Reservoir supply water to the city of Durham. Falls Lake, the largest of the three reservoirs, supplies water to the city of Raleigh and other nearby municipalities. Most of the development is drained by the Little River between the Little River Reservoir and where the Little River discharges into the Eno River (fig. 1). Tributaries of the Flat River drain the eastern edge of the development. Runoff from the development reaches Falls Lake through the Eno and Flat Rivers. The development accounts for about 1 percent of the total drainage area of Falls Lake. Lake Michie receives no drainage from the development, and the Little River Reservoir receives only minor runoff.

The climate of the study area is characterized by hot, humid summers and mild winters. The mean monthly temperature ranges from about 40 degrees Fahrenheit $\left({ }^{\circ} \mathrm{F}\right)$ in January to $79^{\circ} \mathrm{F}$ in July. Precipitation averages about 46.5 inches per year (National Oceanic and Atmospheric Administration, 1988-2009). The topography in the study area is gently sloping to moderately steep. The area is underlain primarily by slates as part of the Carolina Slate Belt. Granites underlie part of the Flat River Basin, and the soils in the area are predominantly well-drained, sandy loam. Part of the study area is underlain by sedimentary rocks of the Triassic Basin with generally poorly drained soils (U.S. Department of Agriculture, 1976).

\section{Land Use}

Land use prior to the development of Treyburn in 1985 was a combination of agricultural (15 percent) and mixed hard wood and pine forest ( 85 percent). Treyburn originally was planned to include commercial (45 percent) and residential (20 percent) development with completion planned for about 2006 (Treyburn, Durham County, North Carolina, Zoning application for a mixed land use project, app. A, written commun., February 1986).

By 1994, land use in Treyburn included residential, industrial, and recreational development (20 percent) with the remainder being mixed forest and abandoned agricultural lands (80 percent). Between 2006 and 2011, residential and industrial development increased to 24 percent (Brian Pointer, U.S. Geological Survey, oral commun., October 2011), with basinwide land use paralleling the same percentage of development. As of 2011, the 24-percent developed land area includes 1,250 acres of residential, industrial, and recreational land, a 210-acre golf course, and 4,300 acres of undeveloped forest and abandoned agricultural land (Brian Pointer, U.S. Geological Survey, oral commun., October 2011). Upstream from Treyburn in the Little and Flat River Basins, land use in 1988 was forested (55 percent) and agricultural and pasture (38 percent); the remainder (7 percent) was developed (Childress and Bathala, 1997).

\section{Study Sites}

During the initial phase of the study (1988 through 1993; Garrett and Bales, 1995), 17 monitoring sites were active in or near the study area. As development at Treyburn progressed, the focus of the monitoring network was limited to sites in areas that were most affected by land-use changes. Six of the original 17 sites were selected to characterize the water-quality conditions associated with developed and undeveloped land 
in and near Treyburn (fig. 2; table 1). Flat River tributary (site 1T) drains an undeveloped area entirely within Treyburn that was initially planned for commercial land use. Data from site $1 \mathrm{~T}$ provide a baseline for evaluating the effects of development. Little River tributary (site 8T) drains a relatively small area that is densely developed with single-family residences and a golf course. Data from site 10TA, Little River downstream from the Little River tributary, were used to characterize the water quality leaving Little River Reservoir and the forested and residential areas in the western part of Treyburn. Water quality at Little River (site 4T) and Mountain Creek (site 6T), both upstream from the Little River Reservoir, are influenced by upstream agricultural land uses.

Site 6T on Mountain Creek was selected to characterize water quality from a moderately developed area where agricultural land use is being converted to residential land use. Mountain Creek is northwest of Treyburn and unaffected by that development. Data from Flat River (site 5T) were used to characterize water quality in a less developed area where agricultural land is being converted to forest (Childress and Bathala, 1997). Site 6T also is unaffected by the Treyburn development.

\section{Data Collection}

During the October 1998 through September 2009 study period, streamflow and water-quality data were collected at six sites in or near the Treyburn study area (fig. 2; table 1). Waterquality data included measurements of physical water-quality characteristics and analyses of concentrations of nutrients, metals, and pesticides.

\section{Streamflow Data}

Continuous streamflow records were collected at five sites (1T, 4T, 5T, 6T, and 10TA) to facilitate interpretation of water-quality data and to allow for calculation of nutrient loads. Stage was measured by using a pressure transducer and recorded at 15-minute intervals. Periodic measurements of stage and instantaneous streamflow were used to develop a stage-discharge relation for calculating streamflow from continuous stage record (Rantz and others, 1982). Instantaneous streamflow measurements were made following standard USGS methods described by Rantz and others (1982), Mueller and Wagner (2009), and Sauer and Turnipseed (2010). A gaging station could not be installed at site $8 \mathrm{~T}$ because of its proximity to the Treyburn golf course. Thus, instantaneous streamflow measurements were made each time a waterquality sample was collected at this site.

\section{Water-Quality Data}

Water-quality samples were collected at six sites $(1 \mathrm{~T}$, 4T, 5T, 6T, 8T, and 10TA) at varying intervals, approximately eight times a year, and during several storm events during water years 1988-2009 (fig. 2; table 1). Water year is defined as the period from October 1 to September 30 and is designated by the year in which the period ends. For example, water year 1988 is October 1, 1987, to September 30, 1988. Samples were analyzed for nutrients and suspended sediment. Samples for analysis of pesticides generally were collected once per year. Samples for analysis of metals were collected three times per year.

\section{Field and Laboratory Methods}

Water-quality sample collection, handling, and analytical procedures were performed in accordance with methods described for the Triangle Area Water Supply Monitoring Project (Oblinger, 2004) and USGS standard procedures (U.S. Geological Survey, variously dated). Stream samples for inorganic analysis were collected by using the depth-integrated, equal-width increment method; composited in a polycarbonate churn splitter; and processed and preserved according to USGS standard operating procedures (Edwards and Glysson, 1988; Ward and Harr, 1990; Wilde and others, 1998). Water samples for analysis of dissolved constituents were filtered through a 0.45 -micron pore-size membrane-capsule filter. Samples collected for pesticide analysis were collected in glass containers at midstream using a weighted open-mouth sampler or by hand as a grab sample.

Water temperature, $\mathrm{pH}$, specific conductance, and dissolved-oxygen concentration were measured in the field at the time of sample collection. Field instruments were calibrated, and results were documented on a daily basis as part of the USGS quality-assurance program.

Chemical analyses were performed by the USGS National Water Quality Laboratory in Denver, Colorado, by using established methods (Wershaw and others, 1987; Britton and Greeson, 1989; Fishman and Friedman, 1989; Fishman, 1993; Zaugg and others, 1995). Suspended-sediment concentrations were determined in the USGS sediment laboratories in Raleigh, North Carolina, and in Louisville, Kentucky, according to methods and procedures described in Guy (1969). Analytical procedures and reporting levels for chemical constituents in water analyzed by the USGS National Water Quality Laboratory during this study are described by Oblinger (2004). 


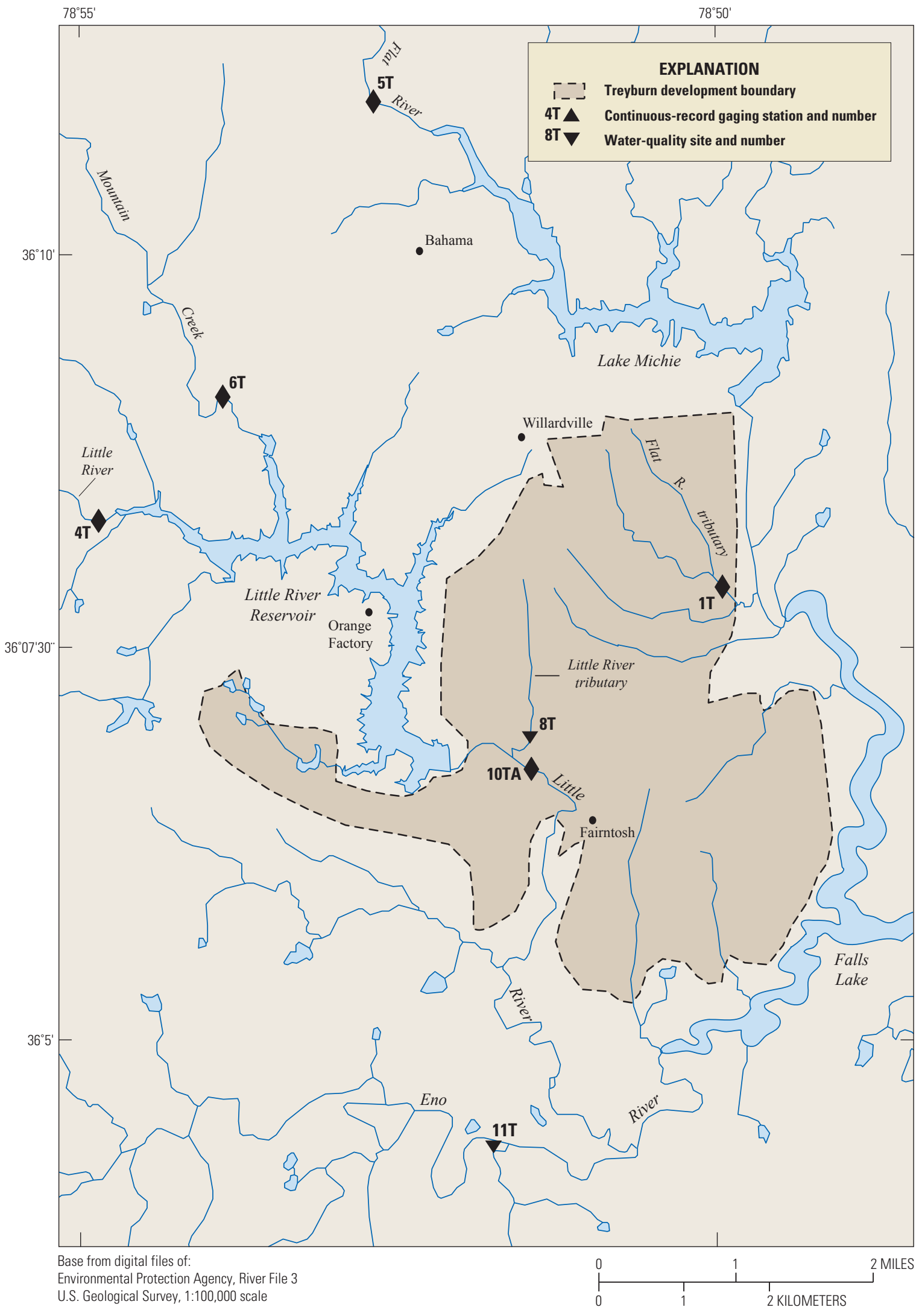

Figure 2. Location of study sites in the vicinity of the Treyburn development area of North Carolina. 


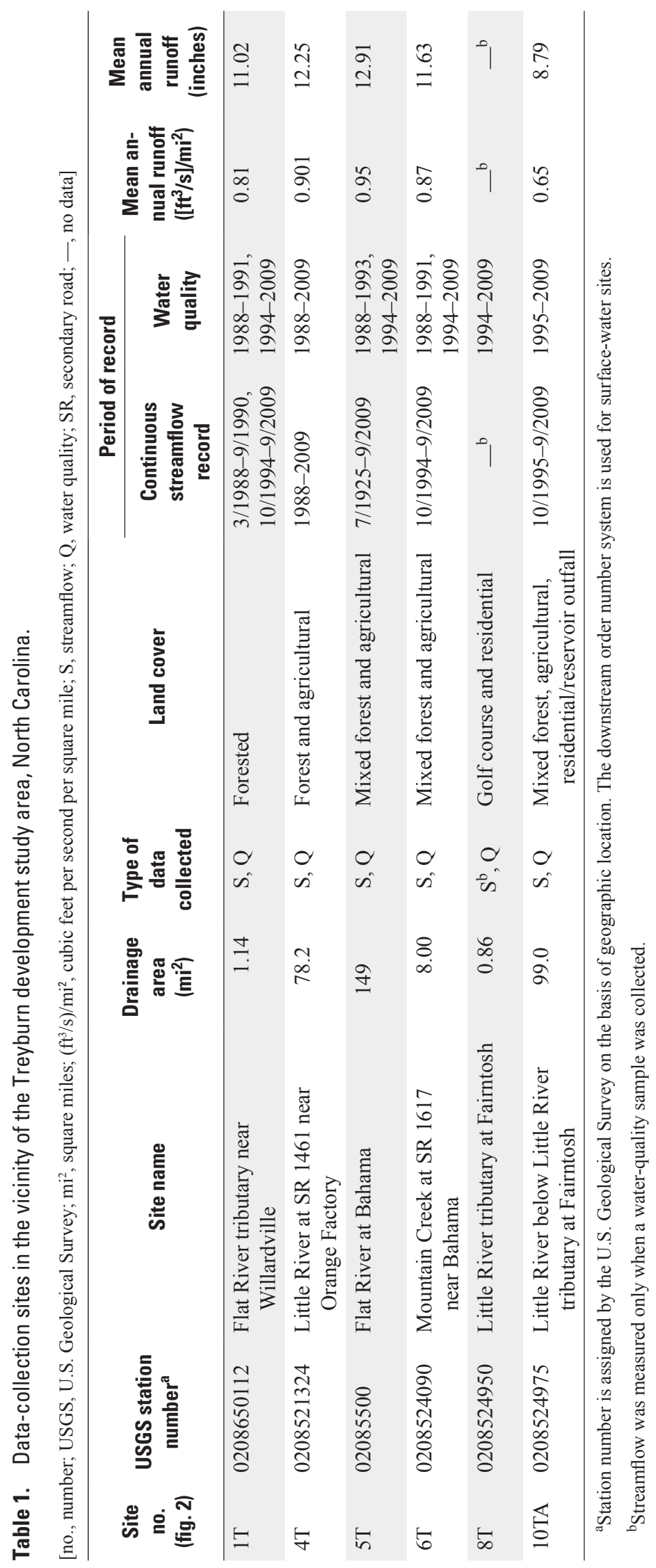




\section{Quality-Assurance Samples}

Two types of quality-assurance samples were collectedreplicates and equipment blanks (table 2). Replicate samples were collected by dividing the composite sample into two separate samples to determine the repeatability of sample analyses. Samples containing water certified as inorganic blank water were run through the sample equipment used for regular sampling onsite to determine if equipment cleaning or sample-processing procedures resulted in contamination by any of the compounds of interest.

Nutrient concentrations in replicate samples are given in table 2. Replicate sample results were generally within 0.01 milligram per liter $(\mathrm{mg} / \mathrm{L})$ of the associated environmental sample results, indicating good analytical repeatability. Metal concentrations in replicate samples are given in table 3. The replicate sample results for metals were all within 5 percent of the environmental sample except for one aluminum sample, indicating good analytical repeatability.

Blank samples were analyzed for nutrients (table 2) and metals (table 3). Concentrations in blank samples generally were at or below the reporting level, which was about an order of magnitude lower than the reporting level for environmental samples. Traces of nutrients and some metals (tables 2 and 3) were found in a small number of equipment blank samples. The levels found were near or below the reporting level for environmental samples for most of the samples. Levels that were detected would not affect the analysis of environmental samples. 


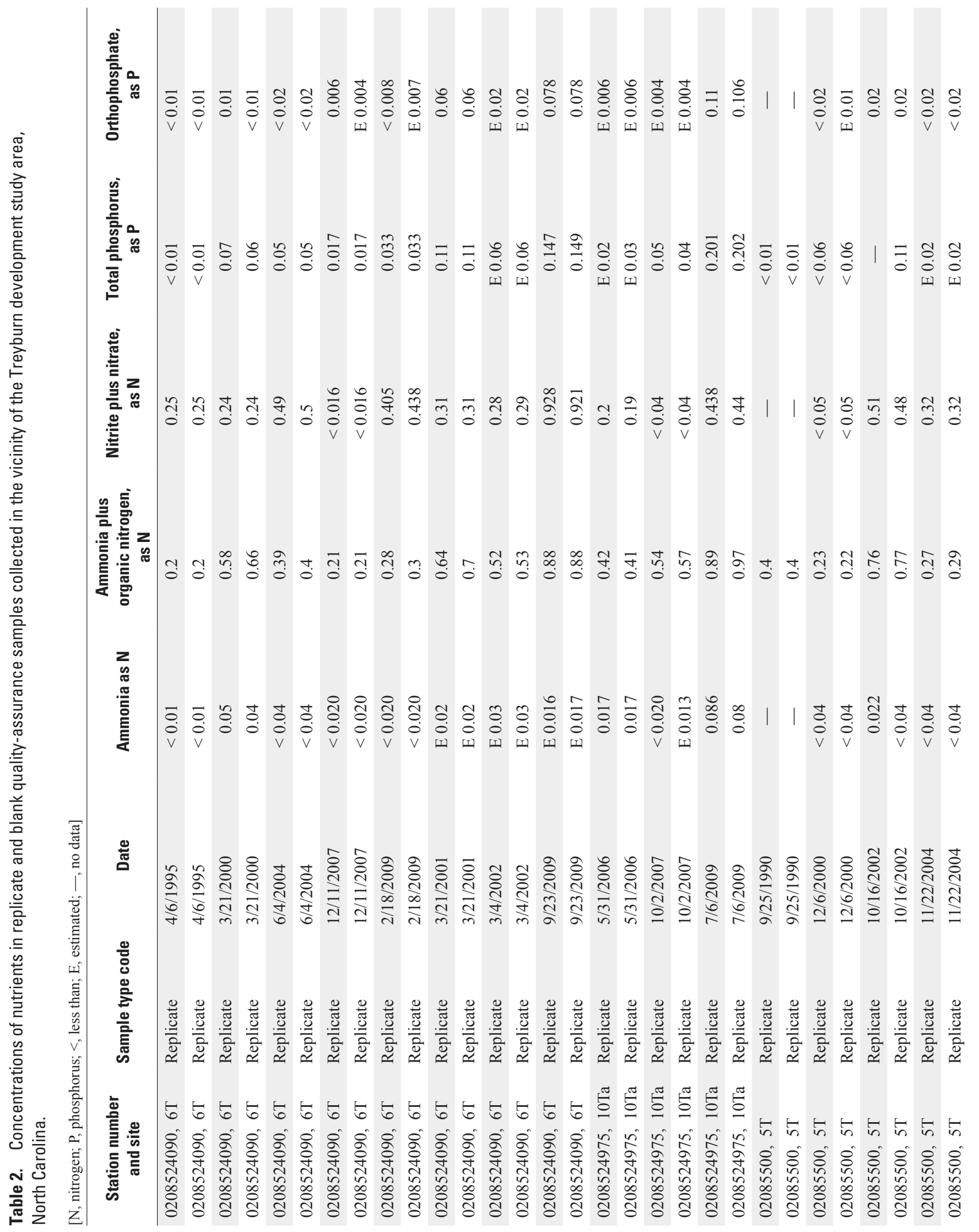


要

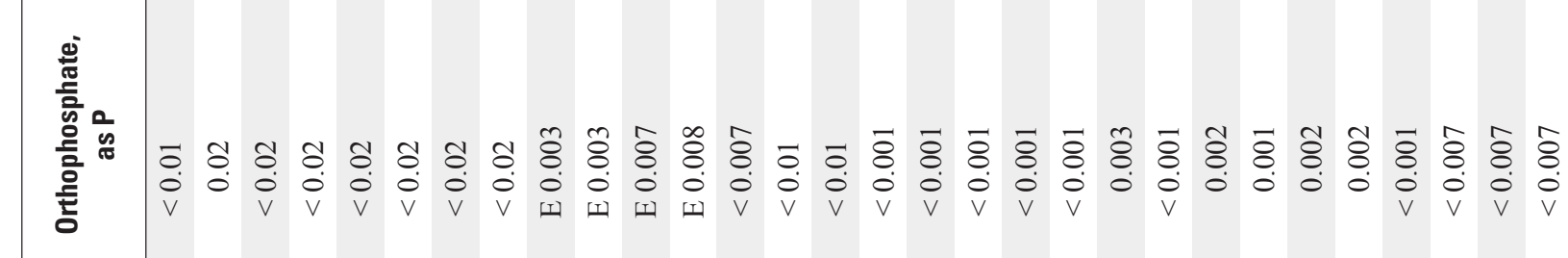

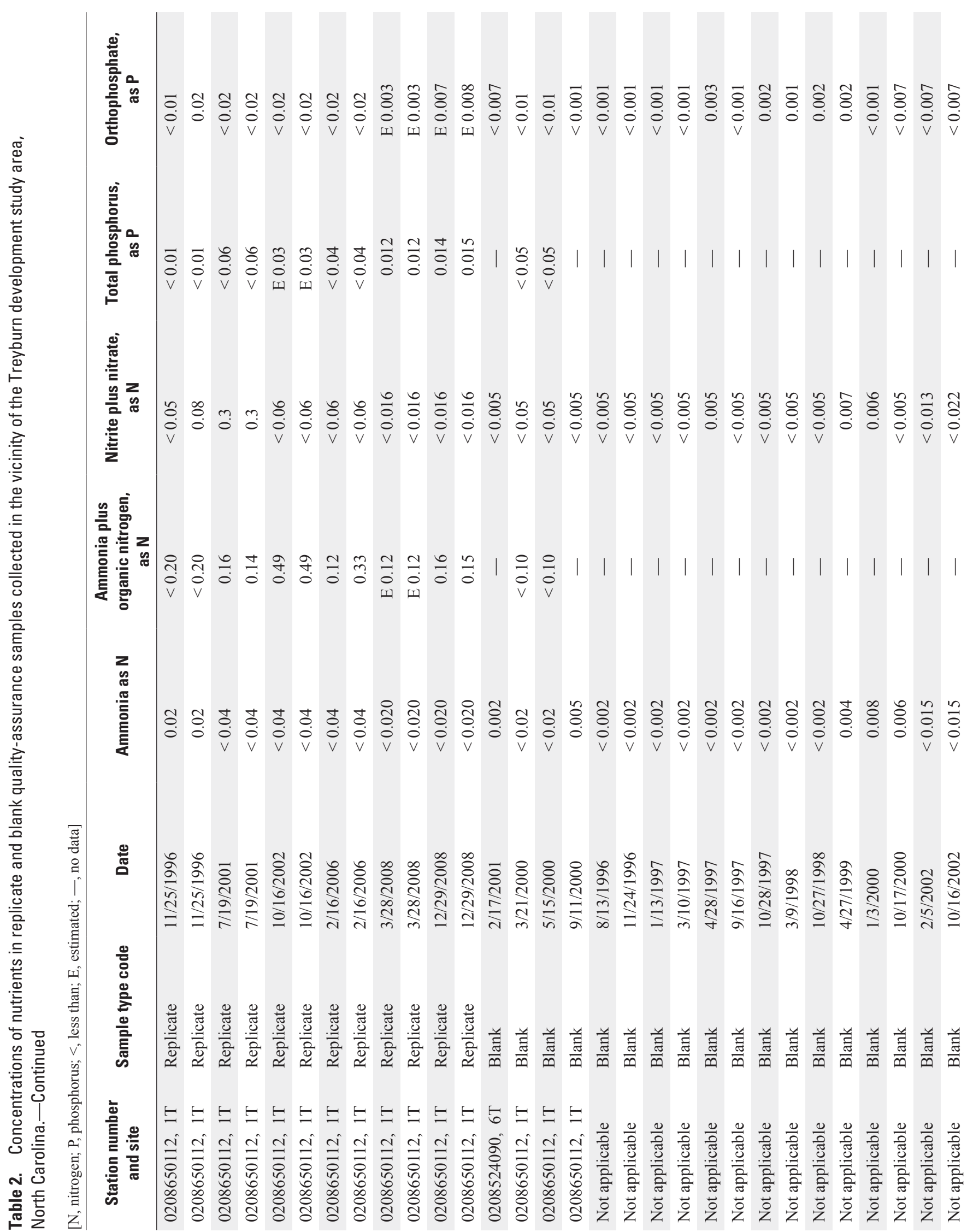




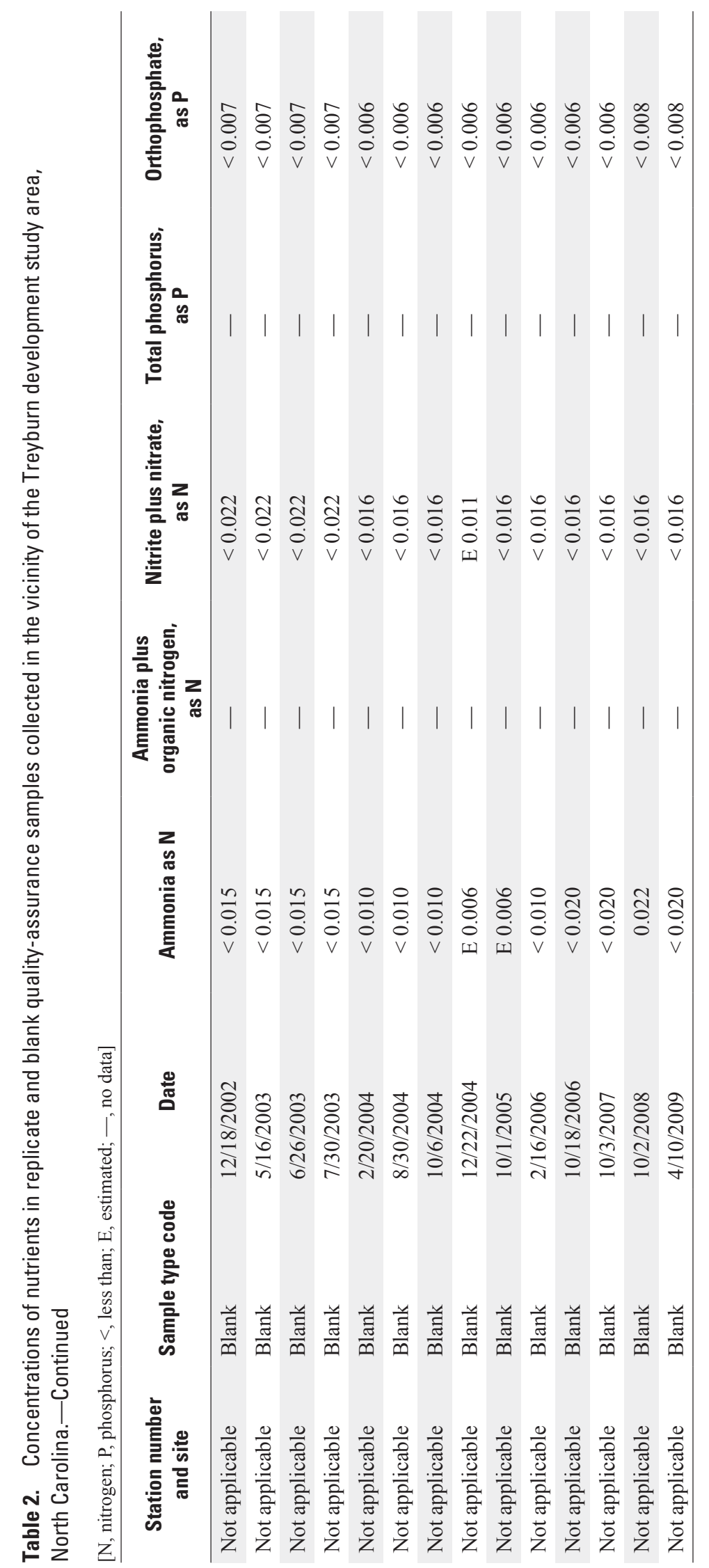




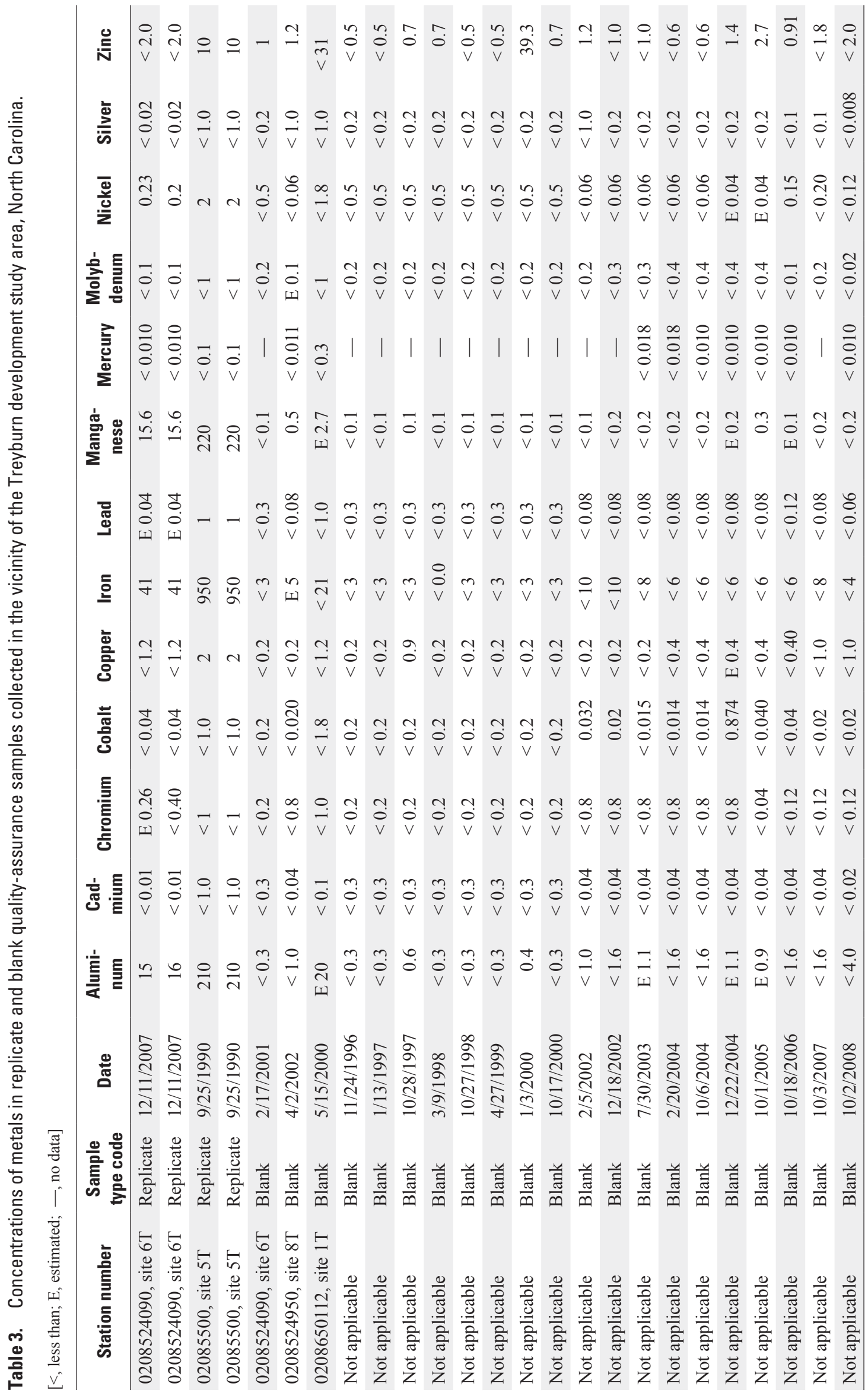




\section{Streamflow Conditions}

Streamflow conditions for water years 1988-2009 were compared to long-term mean discharge (1925-2009) at the Flat River stream gage (site 5T, fig. 3) to provide a context for assessing constituent loads. Higher than average streamflow occurred during 2003 when monthly means were more than double the normal monthly mean streamflow during most months of the year. Average or lower than average streamflow occurred during most of the 1999, 2001, 2002, 2006, 2007, and 2008 water years (at least 9 of 12 months; fig. 3). A major drought occurred during all or parts of 5 consecutive years (1998-2002; Weaver, 2005). Streamflow during 2000, 2004 , and 2005 was near the long-term mean.

The mean annual runoff at each of the gaged sites ranged from 8.79 to 12.91 inches (in.), or 0.65 to 0.95 cubic foot per second per square mile $\left(\left[\mathrm{ft}^{3} / \mathrm{s}\right] / \mathrm{mi}^{2}\right.$; table 1). Estimates of runoff for Little River (site 10TA), Flat River tributary (site 1T), and Mountain Creek (site 6T) are based on 13 to 22 years of streamflow record. Mean annual runoff for Flat River (site 5T) is a long-term mean based on 84 years of record. Yearly precipitation data for a National Oceanic and Atmospheric Administration site in Durham is presented in figure 4. During several years, tropical cyclones (Hurricanes Fran in 1996; Hanna in 2008; and Faye in 2008) contributed almost 20 percent of the annual precipitation.

Continuous streamflow records were not collected at the Little River tributary (site 8T). Instantaneous measurements of discharge at this site were compared to the discharge record for the same date and time at Flat River tributary (site 1T, fig. 5). Flat River tributary has a similar drainage area (table 1) and is within less than $2 \mathrm{mi}$ of the Little River tributary site, so rainfall reasonably was assumed to be similar (fig. 2). Hydrographs of discharge for each gaged site in the Treyburn development study area are displayed in figure 6 . 


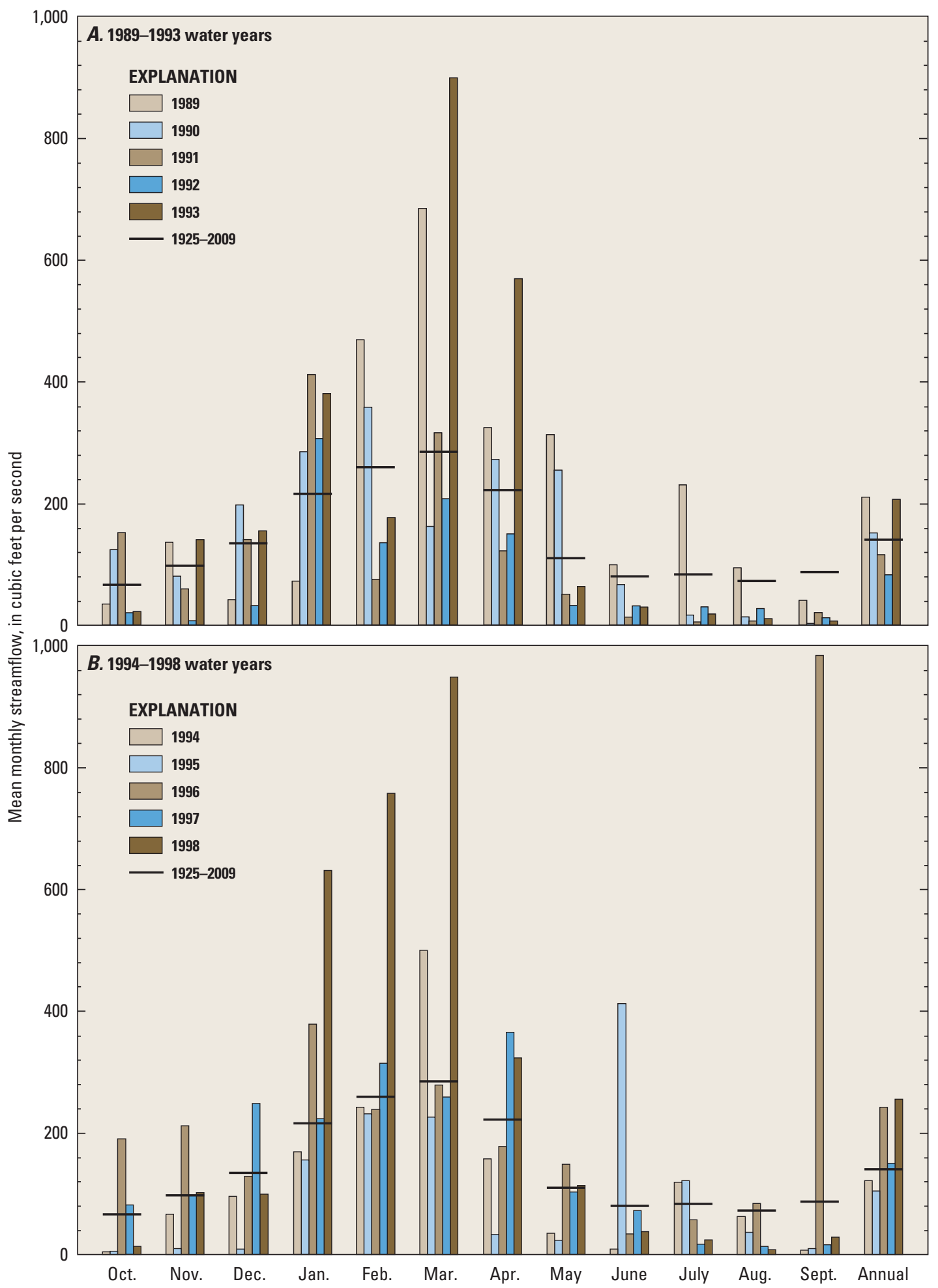

Figure 3. Mean monthly streamflow for water years $A$, 1989-93; $B$, 1994-98; $C$, 1999-2003; $D$, 2004-09, and long-term mean monthly streamflow (1925-2009) at Flat River (site 5T), North Carolina. 


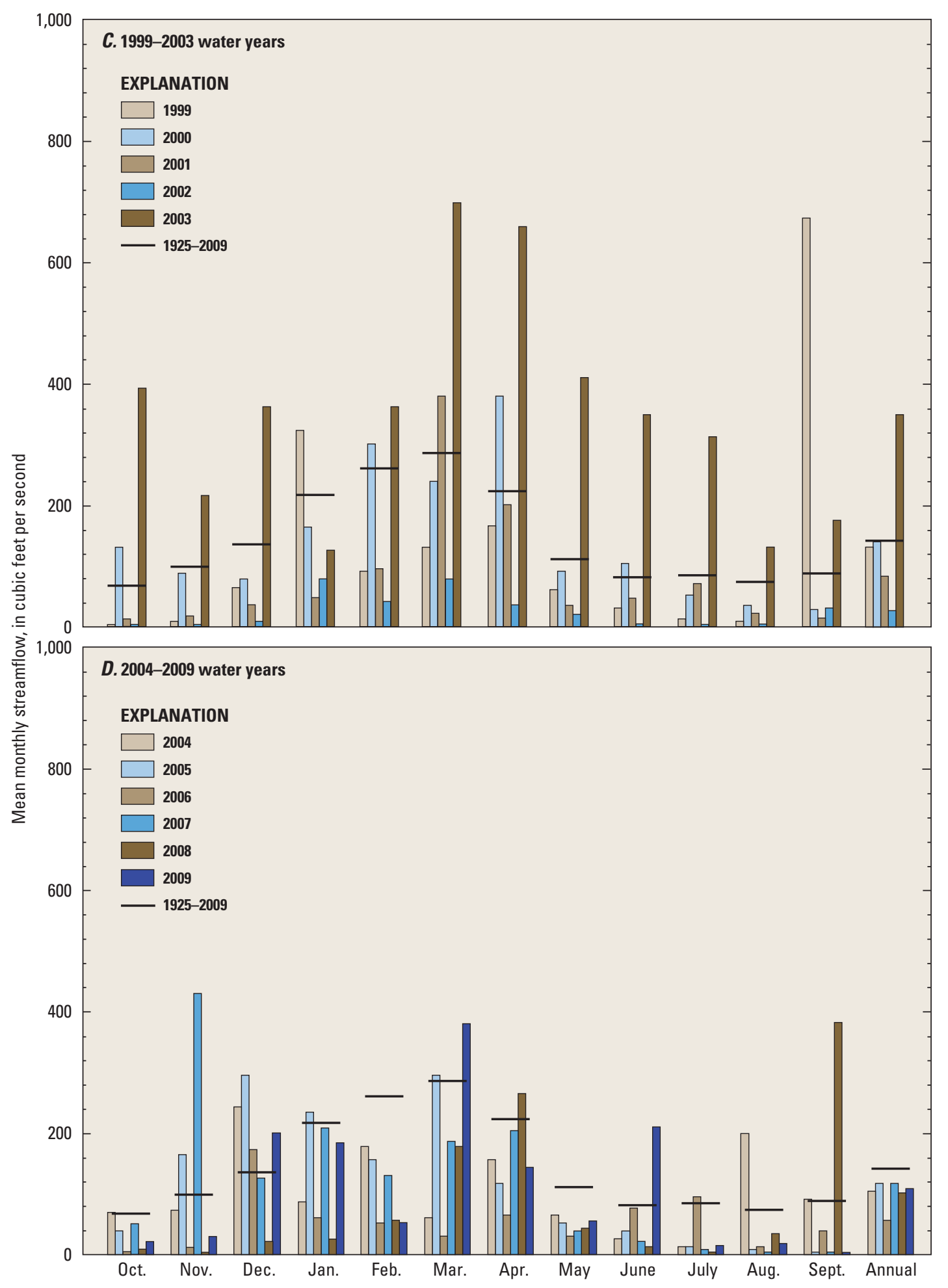

Figure 3. Mean monthly streamflow for water years $A, 1989-93 ; B, 1994-98 ; C, 1999-2003 ; D, 2004-09$, and long-term mean monthly streamflow (1925-2009) at Flat River (site 5T), North Carolina._Continued 


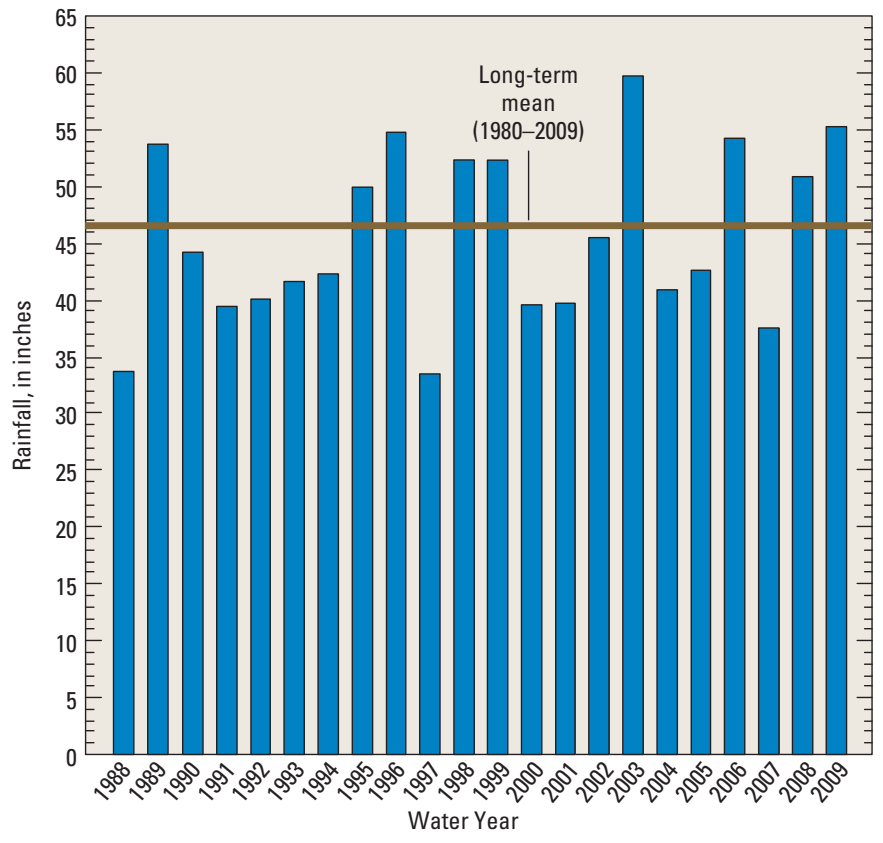

Figure 4. Annual rainfall amounts (1988-2009) and long-term mean annual rainfall (1980-2009) measured at the National Oceanic and Atmospheric Administration site in Durham County, North Carolina.

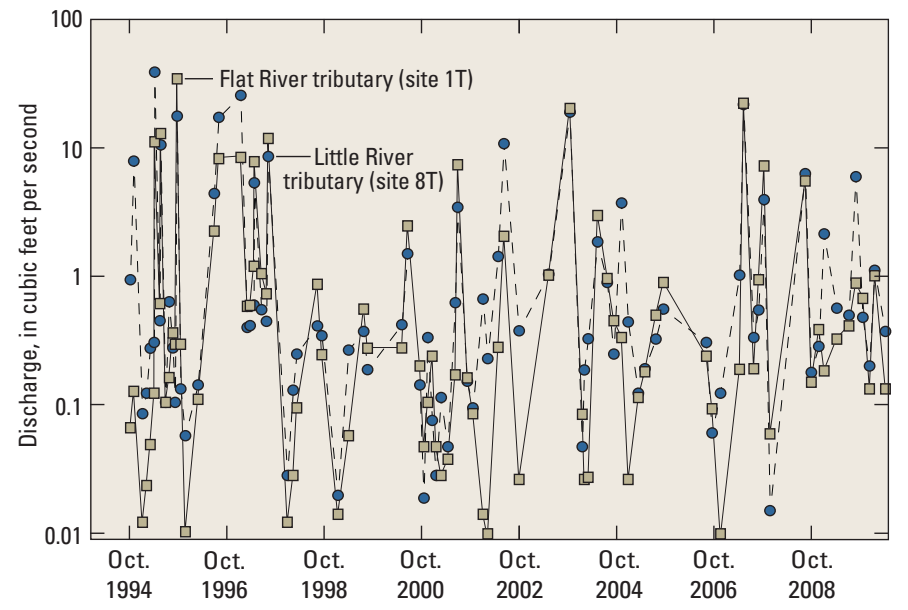

Figure 5. Instantaneous discharge measurements at Flat River tributary (site 1T) and Little River tributary (site 8T) in the vicinity of the Treyburn development study area, North Carolina, 1994-2009. 

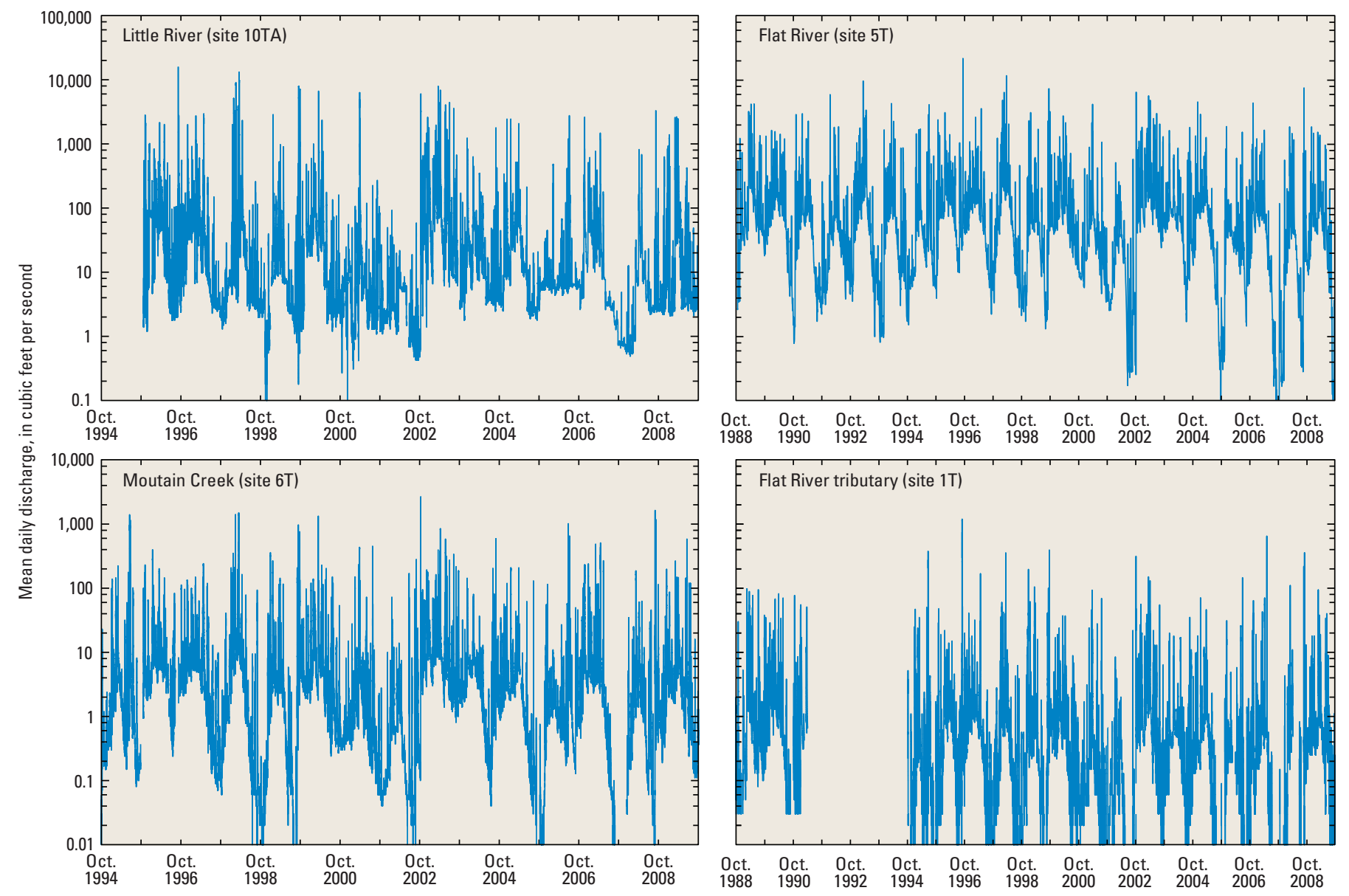

Figure 6. Discharge at the Little River below Little River tributary (site 10TA), Flat River (site 5T), Mountain Creek (site 6T), and Flat River tributary (site 1T) sites in the vicinity of the Treyburn development study area, North Carolina.

\section{Water-Quality Conditions}

Physical properties, suspended sediment, nutrients, metals, and pesticides were measured during the 1988-2009 period of record in surface water collected at the six study sites. A summary of the results of these analyses is presented in this report to characterize water quality at each site and make comparisons among sites.

The Flat River tributary site (site 1T) reflects waterquality conditions unaffected by development and was used as a baseline for comparison with the other Treyburn sites. Water-quality data from a study of forested basins, considered representative of background conditions, in the North Carolina Piedmont by Caldwell (1992) were also used to characterize data from the study sites. Caldwell (1992) used two relatively undisturbed forested basins in the Piedmont to determine background concentrations of selected chemical constituents during both high- and low-flow conditions.

\section{Specific Conductance}

Specific conductance is a measure of the ability of water to conduct an electric current and is a function of the amount and type of ionic material dissolved in water. In forested basins in the North Carolina Piedmont, specific conductance generally ranges from 5 to 56 microsiemens per centimeter at 25 degrees Celsius ( $\mu \mathrm{S} / \mathrm{cm}$; Simmons and Heath, 1982).

The lowest median value of specific conductance in this study $(68 \mu \mathrm{S} / \mathrm{cm})$ occurred at the mostly forested Flat River tributary (site 1T) within a range for all study sites of 25 to $265 \mu \mathrm{S} / \mathrm{cm}$ (table 4). The highest median conductance occurred at the Little River tributary (site $8 \mathrm{~T} ; 158 \mu \mathrm{S} / \mathrm{cm}$ ), which was significantly different from the other sites (Kruskal-Wallis and Tukey multiple comparison tests with a 95 percent confidence level $(\mathrm{p}=0.05))$. The remaining sites had lower or similar specific conductance values (fig. 7) to the Flat River tributary (site 1T). These results are similar to the 1994-98 study-period analyses 
Table 4. Summary statistics for physical properties and suspended sediment collected at six sites in the vicinity of the Treyburn development study area, North Carolina, 1988-2009.

[Median the same as 50th percentile; $<$, less than]

\begin{tabular}{|c|c|c|c|c|c|c|c|}
\hline Statistic & $\begin{array}{l}\text { North Carolina ambient } \\
\text { water-quality criteria }\end{array}$ & $\begin{array}{l}\text { Little River } \\
\text { (site 4T) }\end{array}$ & $\begin{array}{c}\text { Mountain } \\
\text { Creek } \\
\text { (site 6T) }\end{array}$ & $\begin{array}{c}\text { Little River } \\
\text { tributary } \\
\text { (site 8T) }\end{array}$ & $\begin{array}{l}\text { Little River } \\
\text { below } \\
\text { Little River } \\
\text { tributary } \\
\text { (site 10TA) }\end{array}$ & $\begin{array}{l}\text { Flat River } \\
\text { (site } 5 T \text { ) }\end{array}$ & $\begin{array}{c}\text { Flat River } \\
\text { tributary } \\
\text { (site 1T) }\end{array}$ \\
\hline \multicolumn{8}{|c|}{ Specific conductance (microsiemens per centimeter) } \\
\hline Minimum & & 35 & 37 & 41 & 44 & 29 & 25 \\
\hline Median & Not applicable & 77 & 98 & 158 & 80 & 76 & 68 \\
\hline 75th percentile & & 91 & 112 & 197 & 94 & 87 & 84 \\
\hline Maximum & & 115 & 201 & 265 & 143 & 106 & 116 \\
\hline Number of analyses & & 78 & 164 & 142 & 135 & 190 & 169 \\
\hline \multicolumn{8}{|c|}{$\mathrm{pH}$ (standard units) } \\
\hline 25 th percentile & & 6.6 & 6.6 & 6.5 & 6.5 & 6.6 & 6.2 \\
\hline Median & & 6.9 & 6.9 & 6.8 & 6.8 & 6.9 & 6.6 \\
\hline 75th percentile & & 7.2 & 7.2 & 7.1 & 7 & 7.1 & 6.9 \\
\hline Maximum & & 8.1 & 7.7 & 7.4 & 8 & 7.9 & 7.5 \\
\hline Number of analyses & & 77 & 164 & 141 & 134 & 186 & 164 \\
\hline \multicolumn{8}{|c|}{ Dissolved oxygen (milligrams per liter) } \\
\hline Minimum & & 4.6 & 5.8 & 5 & 4 & 3.3 & 2.2 \\
\hline 25 th percentile & 4.0 (minimum instantaneous value) & 8 & 8 & 7.3 & 7.2 & 7.3 & 7.9 \\
\hline Median & & 9.7 & 9 & 8.5 & 8.5 & 8.6 & 9.4 \\
\hline 25 th percentile & & 6.5 & 5 & 7 & 4 & 7 & 5 \\
\hline Median & Not applicable & 28 & 10 & 13 & 10 & 13 & 12 \\
\hline 75th percentile & & 127 & 33 & 41 & 20 & 68 & 42 \\
\hline Maximum & & 476 & 542 & 438 & 267 & 885 & 2,100 \\
\hline Number of analyses & & 53 & 159 & 142 & 135 & 163 & 158 \\
\hline
\end{tabular}

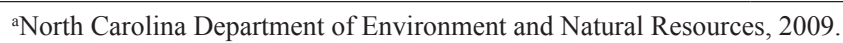



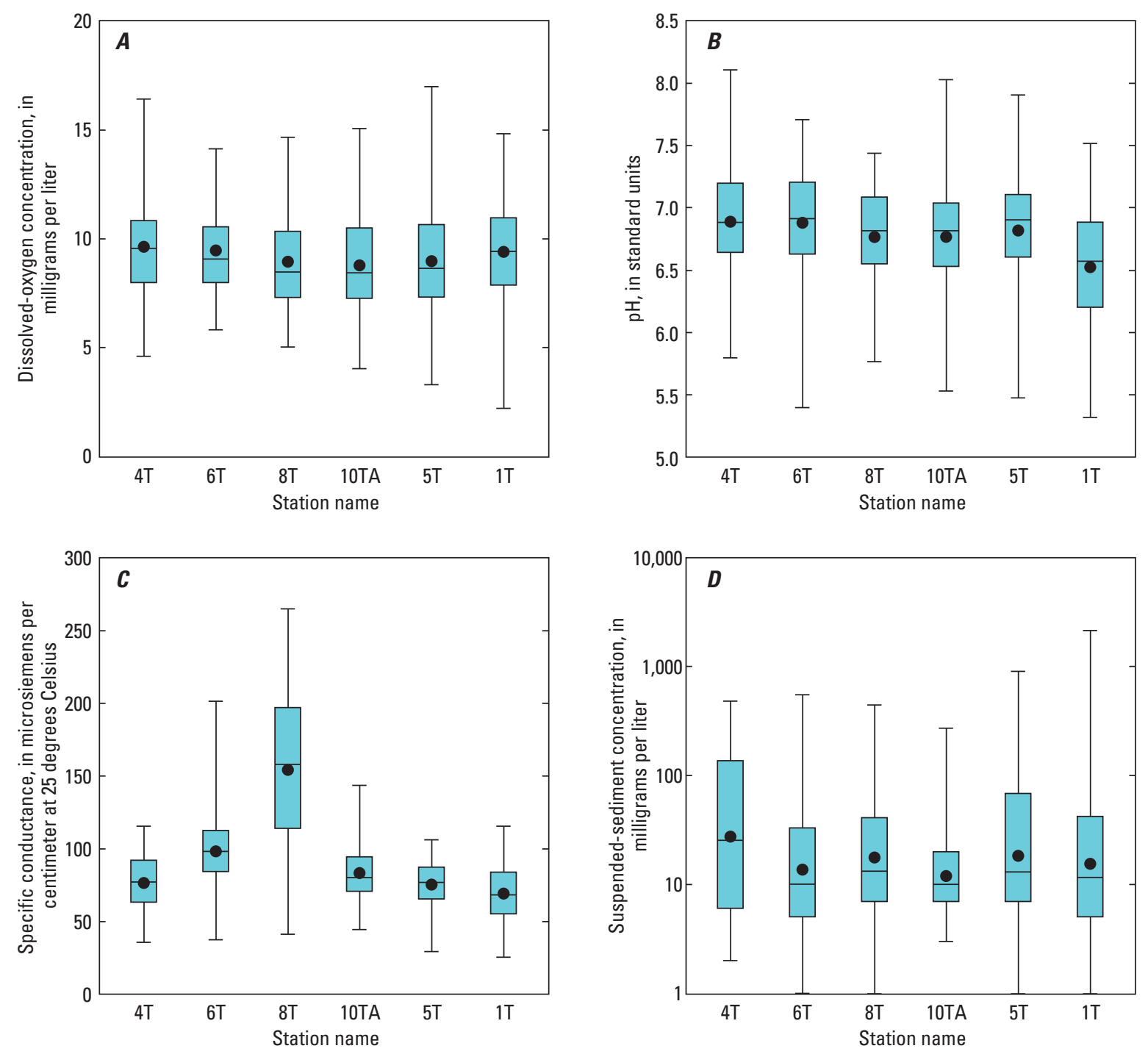

\section{EXPLANATION}

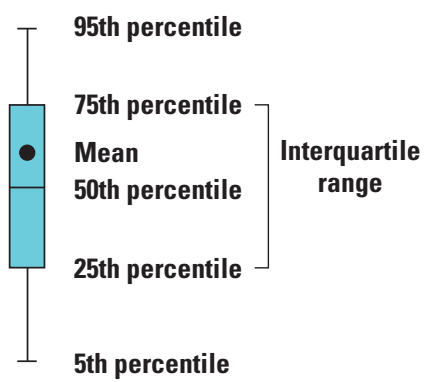

Figure 7. Variability in concentrations of $A$, dissolved-oxygen concentrations; $B, \mathrm{pH} ; C$, specific conductance; and $D$, suspendedsediment concentrations for selected sites in the vicinity of the Treyburn development study area, North Carolina, 1988-2009. 
noted by Oblinger and others (2002). The higher specific conductance noted for the Little River tributary and Mountain Creek may be due to development or differences in geology within these basins.

\section{pH}

The $\mathrm{pH}$ of water is fundamental to the nature of chemical reactions that occur in water. A lower limit of $6.0 \mathrm{pH}$ units has been established by the North Carolina Department of Environment and Natural Resources (2007) as the criterion for waters used for fishing and recreation. Little variation in $\mathrm{pH}$ occurred among the study sites; however, median $\mathrm{pH}$ at Flat River tributary (site 1T) is significantly lower than the other sites. Median values for all the study sites ranged from 6.6 to 6.9, and the range of minimum values was 5.3 to 5.8 (table 4; fig. 7). The Caldwell (1992) study of background conditions in the Piedmont reported $\mathrm{pH}$ values ranging from 5.0 to 7.5.

\section{Dissolved Oxygen}

Dissolved-oxygen concentrations ranged from 2.2 to $17.0 \mathrm{mg} / \mathrm{L}$ (table 4; fig. 7). No significant difference in median dissolved-oxygen concentration was noted among the sites. A lower instantaneous limit of $4.0 \mathrm{mg} / \mathrm{L}$ dissolved oxygen is the criterion for protection of aquatic life (North Carolina Department of Environment and Natural Resources, 2007). The minimum instantaneous dissolved-oxygen concentrations at Flat River (site 5T) and Flat River tributary (site 1T) were below this criterion. Low dissolved-oxygen concentrations in the study basins generally are associated with extreme lowflow conditions.

\section{Suspended Sediment}

Excessive sedimentation is frequently identified as the cause for stream impairment and habitat degradation in North Carolina (North Carolina Division of Water Quality, 2000). Suspended-sediment concentrations at the study sites (table 4; fig. 7) ranged from less than $1 \mathrm{mg} / \mathrm{L}$ at Mountain Creek (site 6T) to $2,100 \mathrm{mg} / \mathrm{L}$ at Flat River tributary (site 1T). Median concentrations ranged from $10 \mathrm{mg} / \mathrm{L}$ at Mountain Creek (site 6T) and at Little River (site 10TA) to $28 \mathrm{mg} / \mathrm{L}$ at Little River near Orange Factory (site 4T). The concentration and median ranges increased from those observed in the study by Oblinger and others (2002). No significant differences in median suspended-sediment concentrations were noted among the sites. The Little River site (site 10TA) was previously reported by Oblinger and others (2002) to have the smallest range in suspended-sediment concentrations during the 1994-98 study period, probably because the site is located downstream from a reservoir that traps some of the sediment. Although the range and the frequency of higher concentrations during the study period increased at the Little River site from those listed in the Oblinger and others study (2002), the range is the smallest among the study sites.

\section{Metals}

Samples were analyzed for total concentrations of aluminum, arsenic, cadmium, cobalt, copper, iron, lead, manganese, mercury, molybdenum, nickel, selenium, silver, and zinc (table 5). Water-quality criteria for the protection of freshwater aquatic life for arsenic, cadmium, copper, iron, lead, manganese, mercury, nickel, selenium, silver, and zinc have been established by the North Carolina Department of Environment and Natural Resources (2007; table 5).

Total iron and manganese concentrations frequently exceeded North Carolina water-quality criteria. Oblinger and others (2002) and Garrett and Bales (1995) reported similar findings in earlier reviews. Median iron concentrations exceeded the 1,000-microgram per liter $(\mu \mathrm{g} / \mathrm{L})$ criterion at all sites except the Flat River tributary (site 1T) and the Little River tributary (site $8 \mathrm{~T}$ ). The 75 th percentile for manganese concentrations exceeded the $200 \mu \mathrm{g} / \mathrm{L}$ criterion for all sites except the Flat River tributary (site 1T). Iron and manganese are common components of area geologic materials and soils.

The frequency at which concentrations of arsenic, cadmium, cobalt, copper, lead, mercury, molybdenum, nickel, selenium, silver, and zinc in water samples from the study area exceeded analytical reporting limits was generally low, typically not exceeding laboratory reporting levels. Concentrations of these metals typically were less than water-quality criteria (North Carolina Department of Environment and Natural Resources, 2007). The highest concentrations of arsenic and lead were in samples from Flat River (site 5T), Mountain Creek (site 6T), and Little River (site 4T); however, the maximum concentrations of arsenic and lead did not exceed criterion levels at any site. Arsenic and lead are naturally present in area soils. Mapped stream data from the Department of Energy National Uranium Resource Evaluation Program indicate high concentrations of arsenic and lead in stream sediment in the study area (Reid, 1993). 
Table 5. Summary statistics for metals and minor elements collected at six sites in the vicinity of the Treyburn development study area, North Carolina, 1988-2009.

[All units in micrograms per liter; median the same as 50th percentile; —, no data; <, less than, which varied throughout the study period]

\begin{tabular}{|c|c|c|c|c|c|c|c|}
\hline Statistic & $\begin{array}{l}\text { North Carolina ambient } \\
\text { water-quality criteria }^{a}\end{array}$ & $\begin{array}{l}\text { Little River } \\
\text { (site 4T) }\end{array}$ & $\begin{array}{l}\text { Mountain } \\
\text { Creek } \\
\text { (site 6T) }\end{array}$ & $\begin{array}{l}\text { Little River } \\
\text { tributary } \\
\text { (site 8T) }\end{array}$ & $\begin{array}{l}\text { Little River below } \\
\text { Little River tributary } \\
\text { (site 10TA) }\end{array}$ & $\begin{array}{l}\text { Flat River } \\
\text { (site 5T) }\end{array}$ & $\begin{array}{l}\text { Flat River } \\
\text { tributary } \\
\text { (site 1T) }\end{array}$ \\
\hline \multicolumn{8}{|c|}{ Aluminum } \\
\hline 25 th percentile & & 100 & 90 & 200 & - & 300 & 100 \\
\hline Median & & 600 & 300 & 600 & - & 700 & 300 \\
\hline Number of analyses & & 40 & 60 & 50 & - & 20 & 60 \\
\hline \multicolumn{8}{|c|}{ Arsenic } \\
\hline Minimum & & $<1$ & $<0.6$ & $<1$ & - & $<1$ & $<1$ \\
\hline 25 th percentile & & $<1$ & $<1$ & $<1.9$ & - & $<1$ & $<1$ \\
\hline Median & & $<5$ & $<1.9$ & 1 & - & $<2$ & $<1.9$ \\
\hline 75th percentile & 50 & 0.75 & $<5$ & 2 & - & $<5$ & $<5$ \\
\hline Minimum & & $<0.04$ & $<0.014$ & $<0.04$ & - & $<0.1$ & $<0.014$ \\
\hline 25th percentile & & $<0.11$ & $<0.22$ & $<0.11$ & - & $<1$ & $<0.22$ \\
\hline Median & & $<1$ & $<1$ & $<1$ & - & $<1$ & $<1$ \\
\hline 75th percentile & 2 & $<5$ & $<1$ & $<1$ & - & $<5$ & $<5$ \\
\hline Maximum & & 1 & 0.61 & 0.066 & - & 1 & 3 \\
\hline Number of analyses & & 58 & 69 & 52 & 一 & 42 & 81 \\
\hline \multicolumn{8}{|c|}{ Chromium } \\
\hline Minimum & & $<0.4$ & $<0.4$ & $<0.8$ & - & $<0.8$ & $<0.8$ \\
\hline 25 th percentile & & $<1$ & $<1$ & $<1$ & - & $<1$ & $<1$ \\
\hline Median & & 0.35 & $<1$ & 0.28 & - & $<5$ & $<5$ \\
\hline 75th percentile & 50 & 2.4 & 0.57 & 0.91 & - & 2 & 1.2 \\
\hline Maximum & & 7.1 & 6.2 & 3 & - & 3 & 5.5 \\
\hline Number of analyses & & 25 & 62 & 52 & - & 24 & 63 \\
\hline \multicolumn{8}{|c|}{ Copper } \\
\hline Minimum & & $<1$ & $<1$ & 1 & - & $<1$ & $<1$ \\
\hline 25 th percentile & & $<50$ & $<50$ & 2.2 & - & $<50$ & $<50$ \\
\hline Median & & 1.2 & 1.4 & 4 & - & 2 & 1.6 \\
\hline 75th percentile & 7 & 3.8 & 3 & 5.3 & - & 4 & 3 \\
\hline Maximum & & 39 & 76 & 10 & - & 81 & 29 \\
\hline Number of analyses & & 58 & 69 & 52 & - & 42 & 81 \\
\hline \multicolumn{8}{|c|}{ Iron } \\
\hline Minimum & & 360 & 40 & 270 & - & 480 & 210 \\
\hline 25 th percentile & & 750 & 770 & 680 & - & 930 & 420 \\
\hline Median & & 1,200 & 1,100 & 860 & - & 1,300 & 690 \\
\hline 75th percentile & 1,000 & 2,200 & 2,200 & 1,400 & - & 2,100 & 1,500 \\
\hline Maximum & & 8,000 & 8,000 & 4,700 & - & 8,300 & 13,000 \\
\hline Number of analyses & & 58 & 68 & 52 & - & 42 & 81 \\
\hline
\end{tabular}


Table 5. Summary statistics for metals and minor elements collected at six sites in the vicinity of the Treyburn development study area, North Carolina, 1988-2009.-Continued

[All units in micrograms per liter; median the same as 50th percentile; - , no data; $<$, less than, which varied throughout the study period]

\begin{tabular}{|c|c|c|c|c|c|c|c|}
\hline Statistic & $\begin{array}{l}\text { North Carolina ambient } \\
\text { water-quality criteria }^{a}\end{array}$ & $\begin{array}{l}\text { Little River } \\
\text { (site 4T) }\end{array}$ & $\begin{array}{l}\text { Mountain } \\
\text { Creek } \\
\text { (site 6T) }\end{array}$ & $\begin{array}{c}\text { Little River } \\
\text { tributary } \\
\text { (site 8T) } \\
\end{array}$ & $\begin{array}{l}\text { Little River below } \\
\text { Little River tributary } \\
\text { (site 10TA) }\end{array}$ & $\begin{array}{l}\text { Flat River } \\
\text { (site 5T) }\end{array}$ & $\begin{array}{c}\text { Flat River } \\
\text { tributary } \\
\text { (site 1T) } \\
\end{array}$ \\
\hline \multicolumn{8}{|c|}{ Lead } \\
\hline 25 th percentile & & $<5$ & $<5$ & $<1$ & - & $<5$ & $<1$ \\
\hline Median & & 0.51 & 1 & 1 & - & 1 & 0.11 \\
\hline 75th percentile & 25 & 2.2 & 2.8 & 1.5 & - & 3 & 1.1 \\
\hline Number of analyses & & 58 & 69 & 52 & - & 42 & 81 \\
\hline \multicolumn{8}{|c|}{ Manganese } \\
\hline Minimum & & 10 & 10 & 60 & - & 20 & 10 \\
\hline 25 th percentile & & 49 & 80 & 110 & - & 75 & 30 \\
\hline Median & & 94 & 200 & 150 & - & 170 & 50 \\
\hline 75th percentile & 200 & 350 & 460 & 260 & - & 270 & 100 \\
\hline Minimum & & $<0.01$ & $<0.01$ & $<0.01$ & - & $<0.01$ & $<0.01$ \\
\hline 25 th percentile & & $<0.1$ & $<0.1$ & $<0.1$ & - & $<0.1$ & $<0.1$ \\
\hline Median & & $<0.1$ & $<0.1$ & $<0.1$ & - & $<0.2$ & $<0.1$ \\
\hline 75th percentile & 0.012 & $<0.2$ & $<0.2$ & 0.01 & - & $<0.2$ & $<0.2$ \\
\hline Maximum & & 0.1 & 1.9 & 0.52 & - & 0.2 & 0.1 \\
\hline Number of analyses & & 62 & 70 & 52 & - & 43 & 80 \\
\hline \multicolumn{8}{|c|}{ Nickel } \\
\hline Minimum & & $<1$ & $<1$ & $<1$ & - & $<1$ & $<1$ \\
\hline 25 th percentile & & $<10$ & $<1$ & $<1.8$ & - & $<5$ & $<1.8$ \\
\hline Median & & 0.7 & $<2$ & 0.41 & - & 1 & 0.36 \\
\hline 75th percentile & 88 & 1.8 & 1 & 1 & - & 3 & 1.2 \\
\hline Number of analyses & & 40 & 62 & 52 & - & 24 & 63 \\
\hline \multicolumn{8}{|c|}{ Silver } \\
\hline Minimum & & $<1$ & $<0.016$ & $<0.016$ & - & $<0.16$ & $<0.016$ \\
\hline 25th percentile & & $<1$ & $<0.30$ & $<0.16$ & - & $<1$ & $<0.43$ \\
\hline Median & & $<1$ & $<1$ & $<0.43$ & - & $<1$ & $<1$ \\
\hline 75th percentile & 0.06 & $<5$ & $<1$ & $<1$ & - & $<5$ & $<1$ \\
\hline Maximum & & 0.14 & 5 & 2 & - & 0.02 & 0.033 \\
\hline Number of analyses & & 41 & 67 & 52 & - & 40 & 77 \\
\hline \multicolumn{8}{|c|}{ Zinc } \\
\hline Minimum & & $<2$ & $<2$ & $<2$ & - & $<10$ & $<2$ \\
\hline 25 th percentile & & $<10$ & $<10$ & $<10$ & - & $<10$ & $<10$ \\
\hline Median & & $<50$ & $<31$ & 1 & - & $<50$ & $<31$ \\
\hline 75th percentile & 50 & 10 & 6.8 & 10 & - & 11 & 2.3 \\
\hline Maximum & & 340 & 44 & 36 & - & 37 & 40 \\
\hline Number of analyses & & 58 & 68 & 51 & - & 42 & 80 \\
\hline
\end{tabular}

\footnotetext{
${ }^{a}$ North Carolina Department of Environment and Natural Resources, 2009.
} 


\section{Nutrients}

Samples from the study sites were analyzed for total ammonia plus organic nitrogen, dissolved nitrite plus nitrate, dissolved nitrate, dissolved ammonia, total phosphorus, and dissolved orthophosphate. Samples from the relatively undisturbed, forested Flat River tributary (site 1T) had the smallest median concentrations and ranges for these nutrients (table 6).

\section{Nitrogen}

Median total ammonia plus organic nitrogen concentrations for the Treyburn study sites ranged from $0.21 \mathrm{mg} / \mathrm{L}$ at the Flat River tributary (site $1 \mathrm{~T}$ ) to $0.52 \mathrm{mg} / \mathrm{L}$ at the Little River below Little River tributary (site 10TA; table 6; fig. 8). Median concentrations of nitrite plus nitrate ranged from $0.06 \mathrm{mg} / \mathrm{L}$ at the Flat River tributary (site 1T) to $0.31 \mathrm{mg} / \mathrm{L}$ at the Mountain Creek site (site 6T; table 6; fig. 8). Caldwell (1992) reported that background Piedmont concentrations of nitrite plus nitrate measured in forested or undeveloped basins ranged from less than 0.10 to $0.44 \mathrm{mg} / \mathrm{L}$. Median ammonia concentrations for the treyburn study sites ranged from less than $0.04 \mathrm{mg} / \mathrm{L}$ at the Flat River Tributary site (site 1T) to $0.04 \mathrm{mg} / \mathrm{L}$ at Little River below Little River tributary (site 10TA; table 6; fig. 8). The Caldwell (1992) study reported that ammonia concentrations in forested or undeveloped basins ranged from 0.01 to 0.08 $\mathrm{mg} / \mathrm{L}$. Median total nitrogen concentrations for the Treyburn sites ranged from $0.39 \mathrm{mg} / \mathrm{L}$ at Flat River tributary (site 1T) to $0.88 \mathrm{mg} / \mathrm{L}$ at Little River (site 4T; table 6; fig. 8). Background total nitrogen concentrations (Caldwell, 1992) ranged from less than 0.02 to $1.5 \mathrm{mg} / \mathrm{L}$. The median values for total ammonia plus organic nitrogen, dissolved ammonia, dissolved nitrite plus nitrate, and total nitrogen concentration for the least developed site, Flat River tributary (site 1T), were lower than the median concentrations for the other sites.

\section{Phosphorus}

Median total phosphorus concentrations ranged from $0.02 \mathrm{mg} / \mathrm{L}$ at the Flat River tributary (site $1 \mathrm{~T}$ ) to $0.06 \mathrm{mg} / \mathrm{L}$ at the Little River (site 4T; table 6; fig. 9). Background Piedmont total phosphorus concentrations reported by Caldwell (1992) ranged from less than 0.01 to $0.11 \mathrm{mg} / \mathrm{L}$. The U.S. Environmental Protection Agency recommended limit of $0.1 \mathrm{mg} / \mathrm{L}$ for total phosphorus concentrations in streams was exceeded at Little River tributary (site 8T) at the 75-percent frequency interval and at all sites at the 95-percent frequency interval. However, phosphorus concentrations for the Treyburn sites generally were low compared to sites nationally (Harned and others, 1995; Mueller and others, 1995; Oblinger and others, 2002). Median orthophosphate concentrations ranged from less than $0.018 \mathrm{mg} / \mathrm{L}$ at Flat River tributary (site 1T) to $0.02 \mathrm{mg} / \mathrm{L}$ at the Little River site (site $4 \mathrm{~T}$; table 6; fig. 9). Orthophosphate generally is present in small concentrations because it is readily bioavailable. 
Table 6. Summary statistics for nutrients detected in stream samples collected at six sites in the vicinity of the Treyburn development study area, 1988-2009.

[All units in milligrams per liter; median the same as 50th percentile; <, less than which, varied throughout the study period]

\begin{tabular}{|c|c|c|c|c|c|c|c|}
\hline Statistic & $\begin{array}{l}\text { North Carolina ambient } \\
\text { water-quality criteria }^{a}\end{array}$ & $\begin{array}{l}\text { Little River } \\
\text { (site 4T) }\end{array}$ & $\begin{array}{l}\text { Mountain } \\
\text { Creek } \\
\text { (site 6T) }\end{array}$ & $\begin{array}{c}\text { Little River } \\
\text { tributary } \\
\text { (site 8T) }\end{array}$ & $\begin{array}{l}\text { Little River below } \\
\text { Little River tributary } \\
\text { (site 10TA) }\end{array}$ & $\begin{array}{l}\text { Flat River } \\
\text { (site 5T) }\end{array}$ & $\begin{array}{c}\text { Flat River } \\
\text { tributary } \\
\text { (site 1T) }\end{array}$ \\
\hline \multicolumn{8}{|c|}{ Total ammonia plus organic nitrogen } \\
\hline Minimum & & $<0.18$ & $<0.20$ & $<0.20$ & 0.28 & 0.13 & $<0.10$ \\
\hline 25 th percentile & & 0.38 & 0.29 & 0.28 & 0.44 & 0.30 & 0.12 \\
\hline Median & & 0.50 & 0.34 & 0.42 & 0.52 & 0.40 & 0.21 \\
\hline Number of samples & & 60 & 164 & 143 & 135 & 169 & 158 \\
\hline \multicolumn{8}{|c|}{ Nitrite plus nitrate } \\
\hline Minimum & & 0.04 & 0.02 & $<0.04$ & 0.03 & $<0.016$ & $<0.016$ \\
\hline 25 th percentile & & 0.17 & 0.20 & 0.07 & 0.14 & 0.13 & $<0.06$ \\
\hline Median & 10 (nitrate) & 0.26 & 0.31 & 0.13 & 0.23 & 0.23 & 0.06 \\
\hline \multicolumn{8}{|c|}{ Ammonia } \\
\hline Minimum & & $<0.020$ & $<0.015$ & $<0.015$ & $<0.015$ & $<0.002$ & $<0.015$ \\
\hline 25 th percentile & & $<0.02$ & $<0.02$ & $<0.04$ & 0.02 & $<0.04$ & $<0.02$ \\
\hline Median & & 0.01 & 0.01 & 0.03 & 0.04 & 0.02 & $<0.04$ \\
\hline 75th percentile & Not applicable & 0.02 & 0.04 & 0.04 & 0.06 & 0.04 & 0.01 \\
\hline Maximum & & 0.13 & 0.32 & 1.95 & 0.27 & 0.14 & 0.12 \\
\hline Number of samples & & 34 & 145 & 143 & 135 & 143 & 134 \\
\hline \multicolumn{8}{|c|}{ Total nitrogen } \\
\hline Minimum & & 0.36 & 0.31 & 0.19 & 0.38 & 0.26 & 0.12 \\
\hline 25 th percentile & & 0.67 & 0.61 & 0.41 & 0.61 & 0.52 & 0.26 \\
\hline Median & & 0.06 & 0.04 & 0.04 & 0.04 & 0.04 & 0.02 \\
\hline 75th percentile & Not applicable & 0.18 & 0.08 & 0.15 & 0.07 & 0.07 & 0.04 \\
\hline Maximum & & 0.59 & 0.67 & 0.87 & 0.45 & 0.43 & 0.23 \\
\hline Number of samples & & 58 & 164 & 143 & 135 & 168 & 159 \\
\hline \multicolumn{8}{|c|}{ Orthophosphate } \\
\hline Minimum & & 0.01 & $<0.006$ & $<0.01$ & $<0.006$ & $<0.006$ & $<0.001$ \\
\hline 25 th percentile & & 0.01 & $<0.018$ & $<0.018$ & $<0.018$ & $<0.018$ & $<0.01$ \\
\hline Median & & 0.02 & 0.01 & 0.01 & 0.01 & 0.01 & $<0.018$ \\
\hline 75th percentile & Not applicable & 0.03 & 0.02 & 0.07 & 0.02 & 0.02 & 0.01 \\
\hline Maximum & & 0.08 & 0.18 & 0.76 & 0.32 & 0.18 & 0.12 \\
\hline Number of samples & & 31 & 145 & 143 & 135 & 140 & 134 \\
\hline
\end{tabular}

${ }^{\mathrm{a}}$ North Carolina Department of Environment and Natural Resources, 2009. 

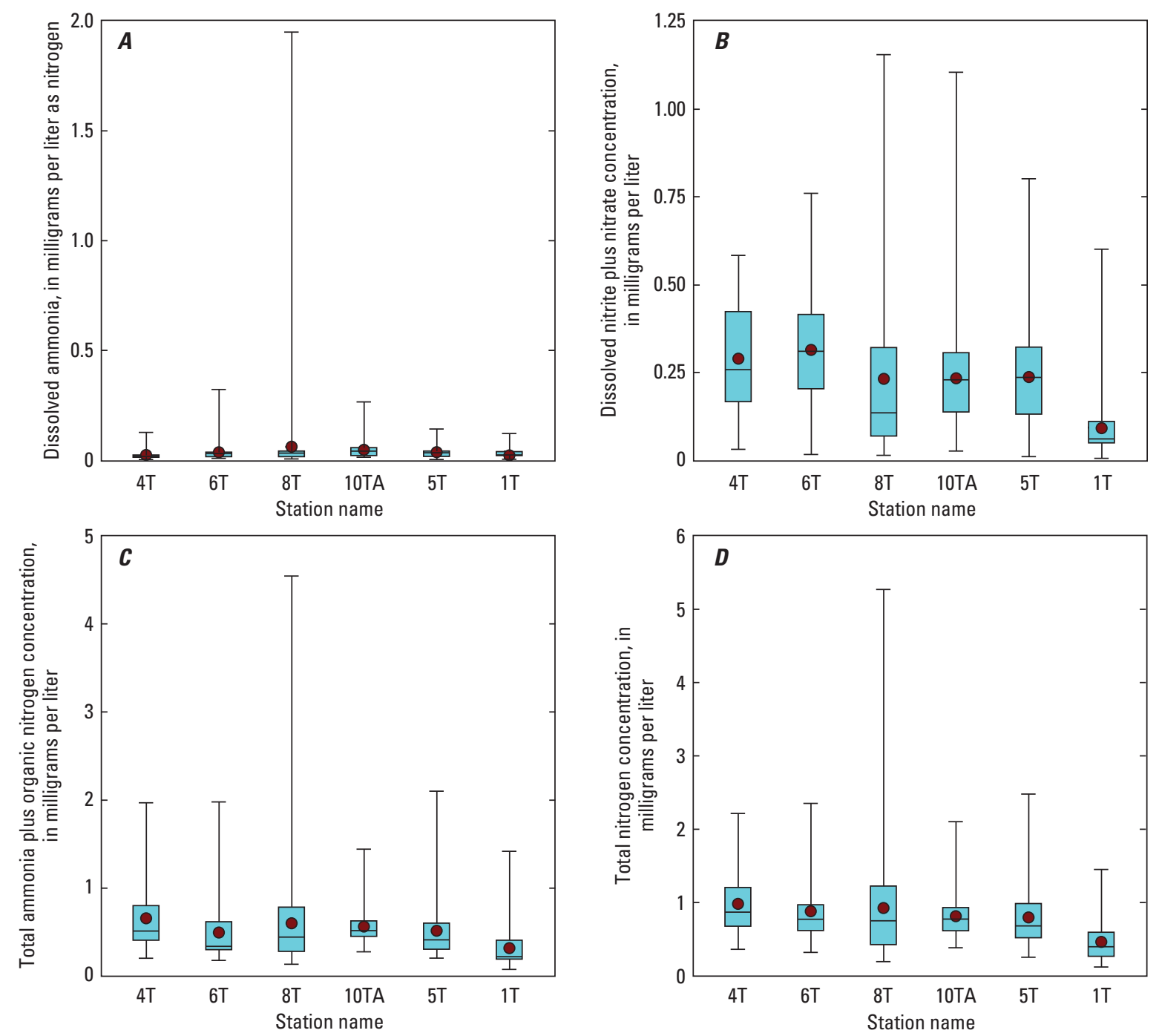

EXPLANATION

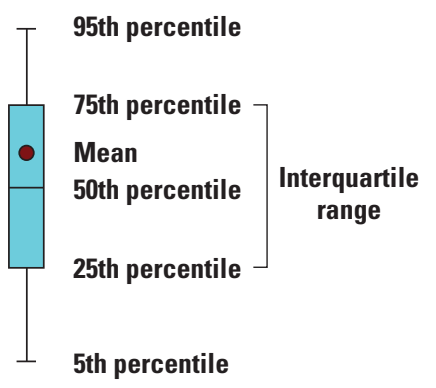

Figure 8. Variability in concentrations of $A$, dissolved ammonia; $B$, dissolved nitrite plus nitrate; $C$, total ammonia plus organic nitrogen; and $D$, total nitrogen for selected sites in the vicinity of the Treyburn development study area, North Carolina, 1988-2009. 

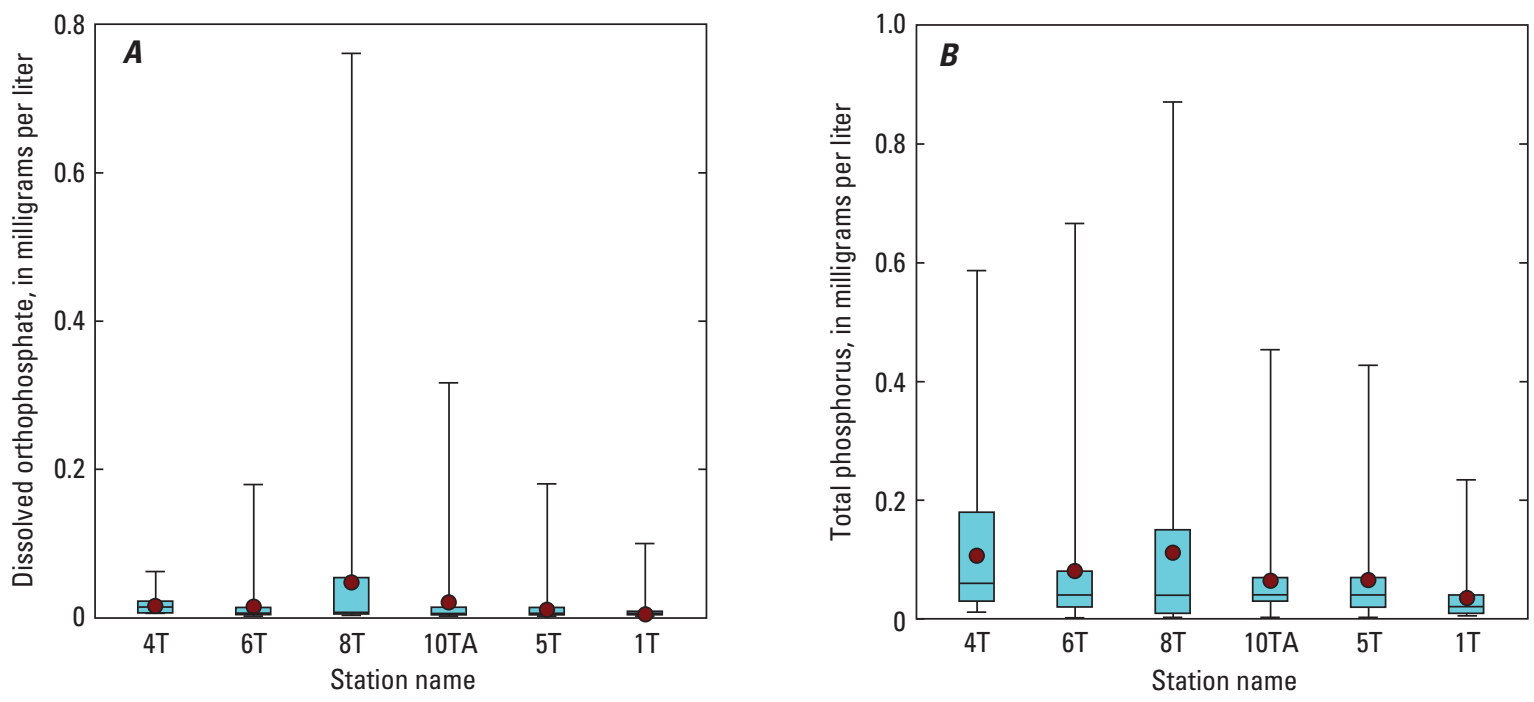

\section{EXPLANATION}

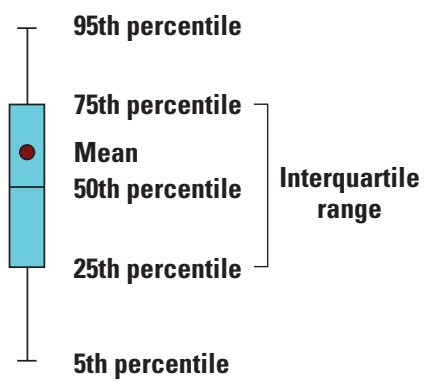

Figure 9. Variability in concentrations of $A$, dissolved orthophosphate, and $B$, total phosphorus for selected sites in the vicinity of the Treyburn development study area, North Carolina, 1988-2009.

\section{Pesticides}

Water samples for analysis of selected pesticides were collected twice a year until 1998 and, thereafter, approximately once a year at Mountain Creek (site 6T), Little River tributary (site 8T), and Flat River tributary (site 1T). The 12 most commonly detected pesticides of the 120 compounds tested (table 7) are listed in table 8.

Little River tributary (site $8 \mathrm{~T}$ ) had the greatest number of pesticides detected and generally the greatest frequency of detections and highest concentrations (table 8). As noted in the previous study of Treyburn (Oblinger and others, 2002), the most commonly detected pesticides were herbicides typically used to control weeds in turf for homes and golf courses.

Four herbicides (atrazine, metolachlor, prometon, and simazine) were frequently detected at Mountain Creek (site 6T) and Little River tributary (site 8T). The herbicide pendimethalin was frequently detected at the Little River tributary (site 8T). Three herbicides (atrazine, metolachlor, and alachlor) were detected at the Flat River tributary (site 1T). Herbicide concentrations at these sites were low compared to sites nationally (Oblinger and others, 2002; Gilliom and others, 2007). 
Table 7. Organic compounds analyzed by the U.S. Geological Survey National Water Quality Laboratory for the Treyburn development project, North Carolina.

[Reporting level, in micrograms per liter, may have changed throughout the duration of the project. -, not applicable]

\begin{tabular}{|c|c|c|}
\hline Compound name & CAS number ${ }^{\mathrm{a}}$ & Reporting level \\
\hline $2,4-\mathrm{D}$ & $94-75-7$ & 0.06 \\
\hline 2,4-D methyl ester & $1928-38-7$ & 0.2 \\
\hline 2,4-D plus 2,4-D methyl ester & - & 0.06 \\
\hline 2,6-Diethylaniline & $579-66-8$ & 0.0060 \\
\hline 2-Chloro-4-isopropylamino-6-amino-s-triazine (CIAT) & $6190-65-4$ & 0.06 \\
\hline 2-Chloro-6-ethylamino-4-amino-s-triazine (CEAT) & $1007-28-9$ & 0.08 \\
\hline 3(4-Chlorophenyl)-1-methyl urea & $5352-88-5$ & 0.10 \\
\hline 3-Hydroxycarbofuran & $16655-82-6$ & 0.06 \\
\hline Acetochlor & $34256-82-1$ & 0.010 \\
\hline Acifluorfen & $50594-66-6$ & 0.08 \\
\hline Alachlor & $15972-60-8$ & 0.008 \\
\hline Aldicarb & $116-06-3$ & 0.12 \\
\hline Aldicarb sulfone & $1646-88-4$ & 0.08 \\
\hline Aldicarb sulfoxide & $1646-87-3$ & 0.08 \\
\hline Aldrin & $309-00-2$ & 0.013 \\
\hline alpha-Endosulfan & $959-98-8$ & 0.012 \\
\hline alpha-HCH & $319-84-6$ & 0.0040 \\
\hline Atrazine & $1912-24-9$ & 0.008 \\
\hline Azinphos-methyl & $86-50-0$ & 0.12 \\
\hline Bendiocarb & $22781-23-3$ & 0.04 \\
\hline Benfluralin & $1861-40-1$ & 0.014 \\
\hline Benomyl & $17804-35-2$ & 0.06 \\
\hline Bensulfuron-methyl & $83055-99-6$ & 0.06 \\
\hline Bentazon & $25057-89-0$ & 0.06 \\
\hline Bromacil & $314-40-9$ & 0.06 \\
\hline Bromoxynil & $1689-84-5$ & 0.12 \\
\hline Butylate & $2008-41-5$ & 0.0040 \\
\hline Caffeine & $58-08-2$ & 0.08 \\
\hline Carbaryl & $63-25-2$ & 0.04 \\
\hline Carbofuran & $1563-66-2$ & 0.04 \\
\hline Carbophenothion & $786-19-6$ & 0.02 \\
\hline Chloramben, methyl ester & $7286-84-2$ & 0.20 \\
\hline Chlordane, technical mix & $57-74-9$ & 0.1 \\
\hline Chlorimuron-ethyl & $90982-32-4$ & 0.08 \\
\hline Chlorpyrifos & $2921-88-2$ & 0.02 \\
\hline cis-Permethrin & $61949-76-6$ & 0.010 \\
\hline Clopyralid & $1702-17-6$ & 0.14 \\
\hline Cyanazine & $21725-46-2$ & 0.022 \\
\hline Cycloate & $1134-23-2$ & 0.04 \\
\hline Dacthal & $1861-32-1$ & 0.0076 \\
\hline Dacthal monoacid & $887-54-7$ & 0.04 \\
\hline Desulfinylfipronil & - & 0.012 \\
\hline Desulfinylfipronil amide & - & 0.029 \\
\hline Diazinon & $333-41-5$ & 0.0060 \\
\hline Dicamba & $1918-00-9$ & 0.06 \\
\hline Dichlorprop & $120-36-5$ & 0.04 \\
\hline Dieldrin & $60-57-1$ & 0.008 \\
\hline Dinoseb & $88-85-7$ & 0.04 \\
\hline Diphenamid & $957-51-7$ & 0.04 \\
\hline Disulfoton & $298-04-4$ & 0.02 \\
\hline Diuron & $330-54-1$ & 0.04 \\
\hline Endrin & $72-20-8$ & 0.012 \\
\hline EPTC & $759-94-4$ & 0.0056 \\
\hline Ethalfluralin & $55283-68-6$ & 0.006 \\
\hline Ethion & $563-12-2$ & 0.018 \\
\hline Ethoprophos & $13194-48-4$ & 0.016 \\
\hline Fenuron & $101-42-8$ & 0.06 \\
\hline Fipronil & $120068-37-3$ & 0.018 \\
\hline Fipronil sulfide & $120067-83-6$ & 0.012 \\
\hline
\end{tabular}


Table 7. Organic compounds analyzed by the U.S. Geological Survey National Water Quality Laboratory for the Treyburn development project, North Carolina.-Continued

[Reporting level, in micrograms per liter, may have changed throughout the duration of the project. —, not applicable]

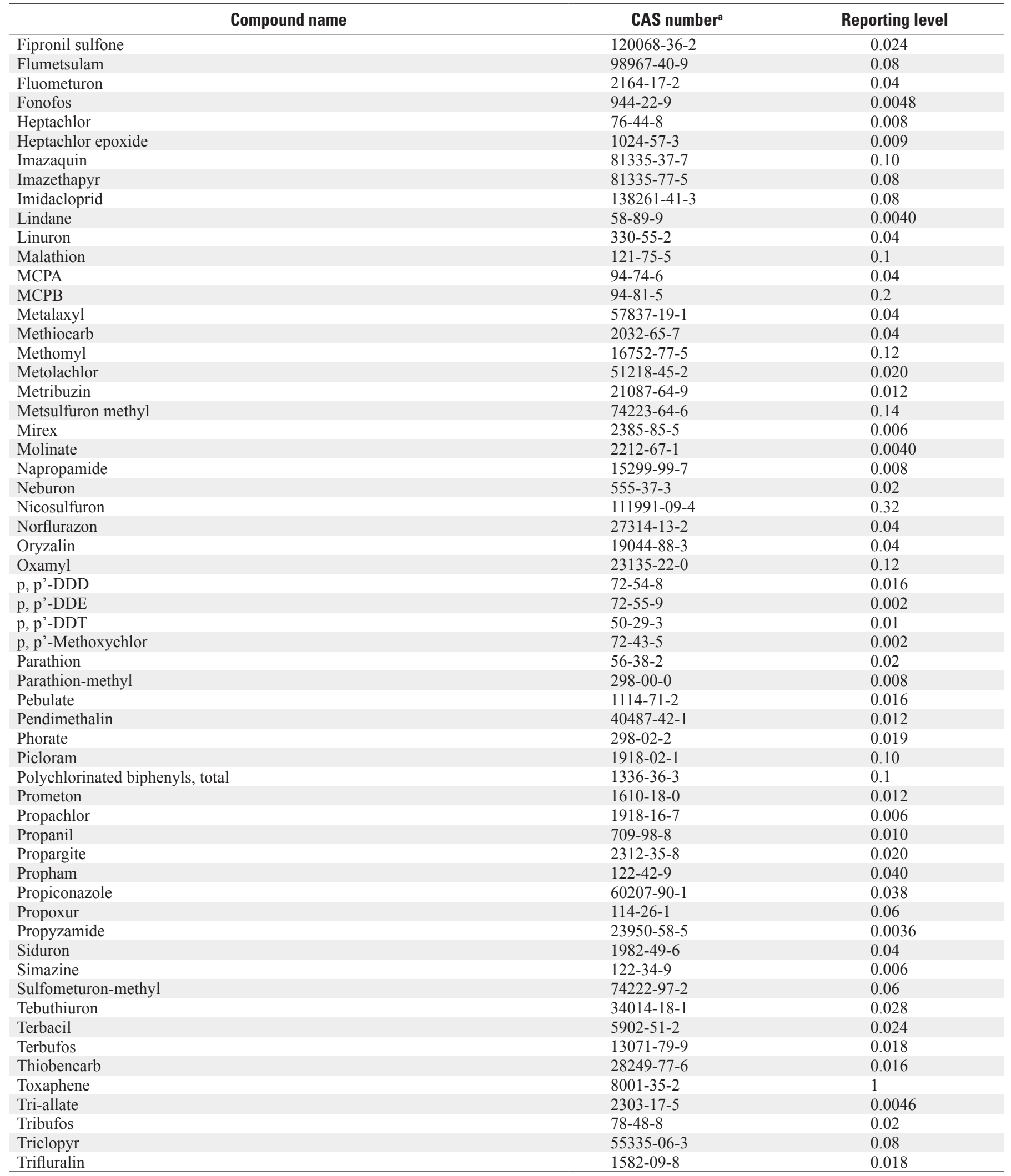

${ }^{\mathrm{a}}$ CAS Registry Number ${ }^{\circledR}$ is a Registered Trademark of the American Chemical Society. CAS recommends the verification of the CASRNs through CAS Client Services. 
Table 8. Concentrations of pesticides that exceed the laboratory reporting level in samples collected at three sites in the vicinity of the Treyburn development study area, North Carolina, 1988-2009.

[Units are in micrograms per liter; $<$, less than]

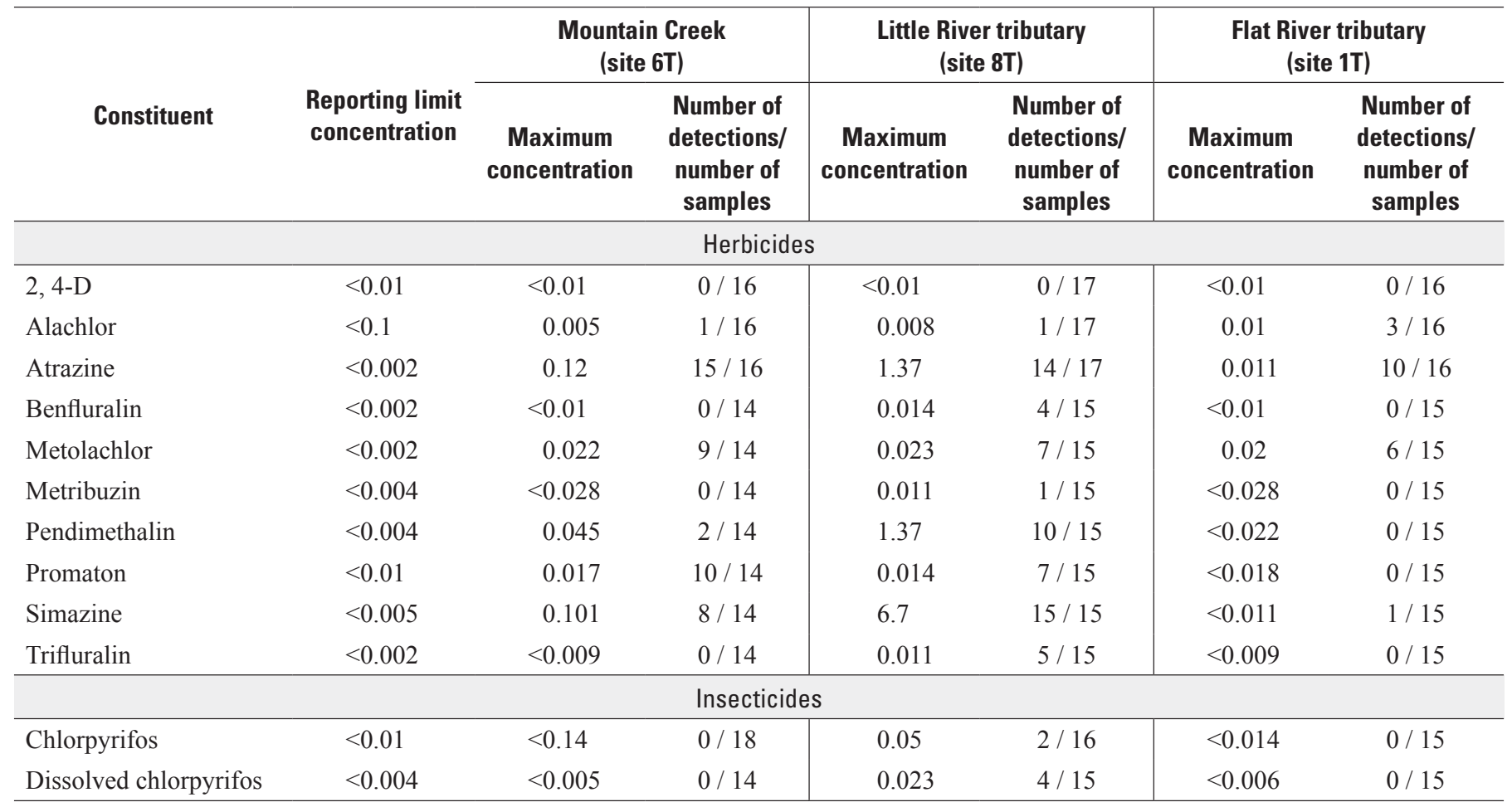

\section{Water-Quality Seasonality}

Water chemistry varies with season. Many factors influence this variation, including seasonal differences in streamflow, temperature, basin land use, and biological activity. Seasonal variation in concentration of chemical constituents is an important factor to account for in trend analysis and in monitoring for resource management.

\section{Suspended Sediment}

Monthly distributions of suspended-sediment concentrations at several Treyburn sites showed seasonality. Little River (site 4T), Mountain Creek (site 6T), Flat River (site 5T), and Eno River (site 11T) showed particularly low suspendedsediment concentrations in June and July, with higher concentrations during the spring and fall. Eno River (site 11T, fig. 1) is included for comparison because it includes data from an earlier (1983-99) pre-study time period. December and January suspended-sediment concentrations were low compared to spring and fall concentrations at the Little River (site 4T), Flat River (site 5T), and Flat River tributary (site 1T) sites. These seasonal patterns are most evident for Little River (site 4T, fig. 10). Possible causes for these seasonal differences may include influences on sediment transport due to decreased erosion caused by leaf cover in the summer and land-surface disturbance due to agricultural or construction activities in the spring and increased source contribution of organic sediment from leaf litter in the fall. Frozen ground in winter may reduce sediment transport.

\section{Dissolved Oxygen}

Dissolved-oxygen concentrations showed a strong seasonal pattern at all the Treyburn study sites. Dissolved-oxygen concentrations generally were highest in February, ranging from 10 to $15 \mathrm{mg} / \mathrm{L}$, and were lowest in July and August, typically ranging from 5 to $9 \mathrm{mg} / \mathrm{L}$. An example of this seasonal pattern is shown in figure 11 for Flat River (site 5T). Oxygen solubility in water varies with temperature. As water temperature decreases, the concentration of oxygen that can dissolve in water increases.

\section{pH}

Measurements of $\mathrm{pH}$ made at the time of sampling showed a pattern of slightly higher summertime levels compared to other seasons for all the sites. The higher measurements may be due to increased biological activity in the summer. Increased $\mathrm{pH}$ means lower hydrogen ion concentration 


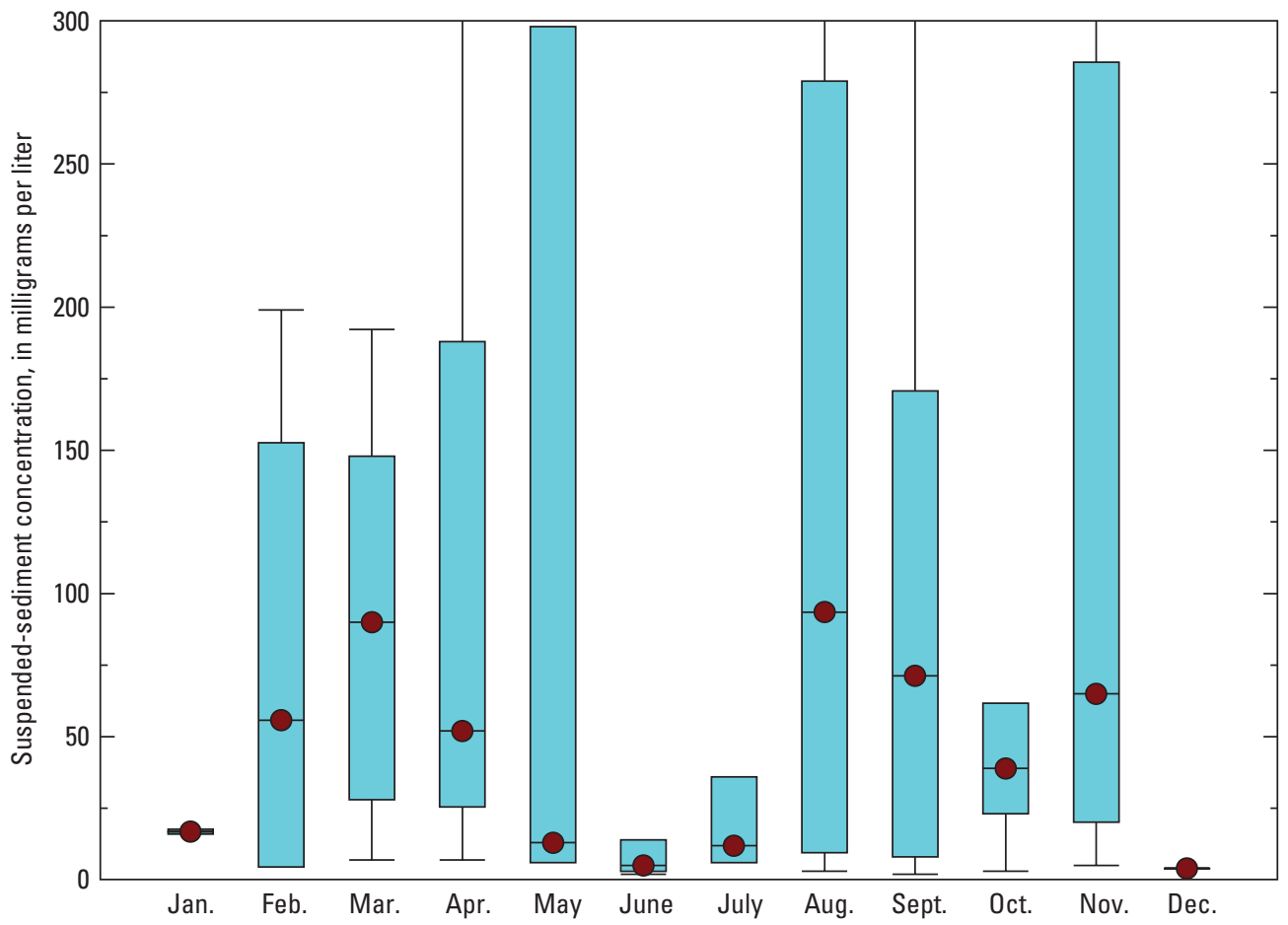

\section{EXPLANATION}

95th percentile

75th percentile

50th percentile

Interquartile

25th percentile range

5th percentile

Figure 10. Monthly suspended-sediment concentrations for Little River (site 4T) in the vicinity of the Treyburn development study area, North Carolina, 1988-2009.

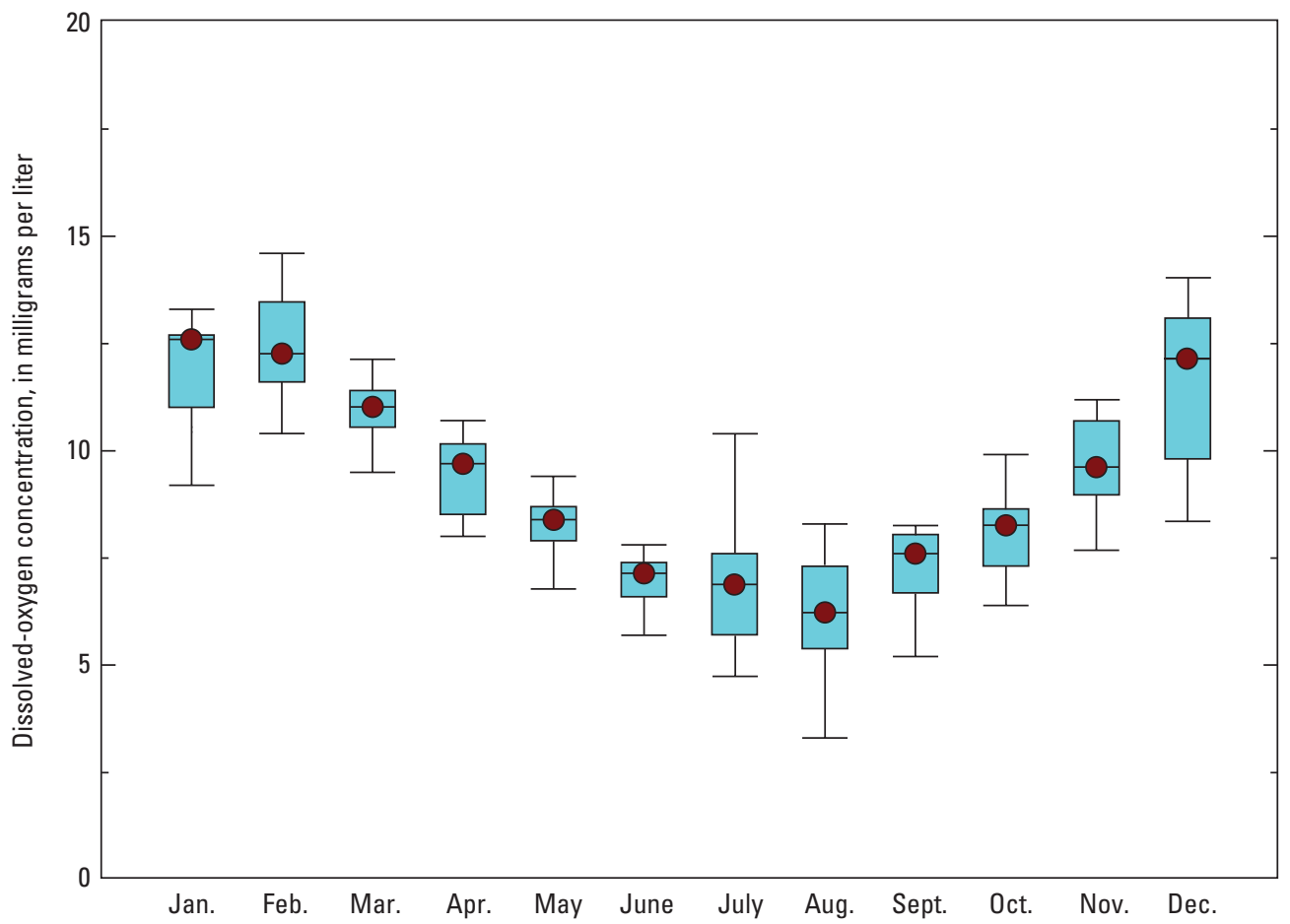

\section{EXPLANATION}

95th percentile

75th percentile

50th percentile

Interquartile

25th percentile

5th percentile

Figure 11. Monthly dissolved-oxygen concentrations for Flat River tributary (site 1T) in the vicinity of the Treyburn development study area, North Carolina, 1988-2009. 
in the water. Biological respiration produces carbon dioxide, which combines with hydrogen ions to form bicarbonate, and a decrease in $\mathrm{pH}$. An example of this pattern is shown by $\mathrm{pH}$ variability for the Flat River (site 5T, fig. 12).

\section{Specific Conductance}

Specific conductance showed a pattern of slightly elevated levels in the summer and fall compared to other seasons for all the sites. An example of this pattern is shown in figure 13 for Little River tributary (site 8T).

\section{Metals}

No distinct seasonal patterns were observed for metals. The occurrences of periods of high or low concentrations appear to be unrelated to season.

\section{Nitrogen}

Seasonal patterns in monthly frequency distributions of nitrogen constituent concentrations were observed for several of the study sites. Nitrate concentrations at Little River below Little River tributary (site 10TA, fig. 14A) peaked in the winter and were lowest in the fall, a pattern also observed for the Flat River, but with low concentrations in late summer as well (site 5T, fig. 14B), and Mountain Creek (site 6T, fig. 14C). This pattern of nitrate concentration, however, is reversed for the Little River tributary (site 8T, fig. 14D), where some of the high nitrate values occurred during the fall. The Little River tributary (site 8T) watershed includes golf course and residential land uses. The higher fall nitrate concentrations may be associated with turf fertilization.

Monthly frequency distributions of ammonia concentrations showed a slight seasonal increase during April through September at Little River tributary (site 8T, fig. 15A) and peaked during June and July at Little River below Little River tributary (site 10TA, fig. 15B). Total ammonia plus organic nitrogen concentrations were highest in the spring at Little River (site 4T, fig. 16A), in the summer at Little River tributary (site 8T, fig. 16B), and from July to November at Little River below Little River tributary (site 10TA, fig. 16C). Total ammonia plus organic nitrogen peaked in the winter and in the fall at Flat River (site 5T, fig. 16D). The summer and spring nutrient increases may reflect the release of nutrients due to decomposition of leaf litter and the increased use of fertilizers.

Total nitrogen concentrations at Little River (site 4T, fig. 17A) and Flat River (site 5T, fig. 17D) generally were lowest during June through August. Concentrations were higher from December through March at Mountain Creek (site 6T, fig. 17B) and Little River below Little River tributary (site 10TA, fig. 17C). Causes of seasonal variation in nitrogen concentrations include variation in nutrient uptake by vegetation in the summer (decreasing nitrogen influx to the streams), land-surface disturbance due to agricultural or construction activities (increasing nitrogen inputs), fertilizer application in the spring and fall (increasing concentrations), and predominance of groundwater inflow (generally decreasing concentrations). 

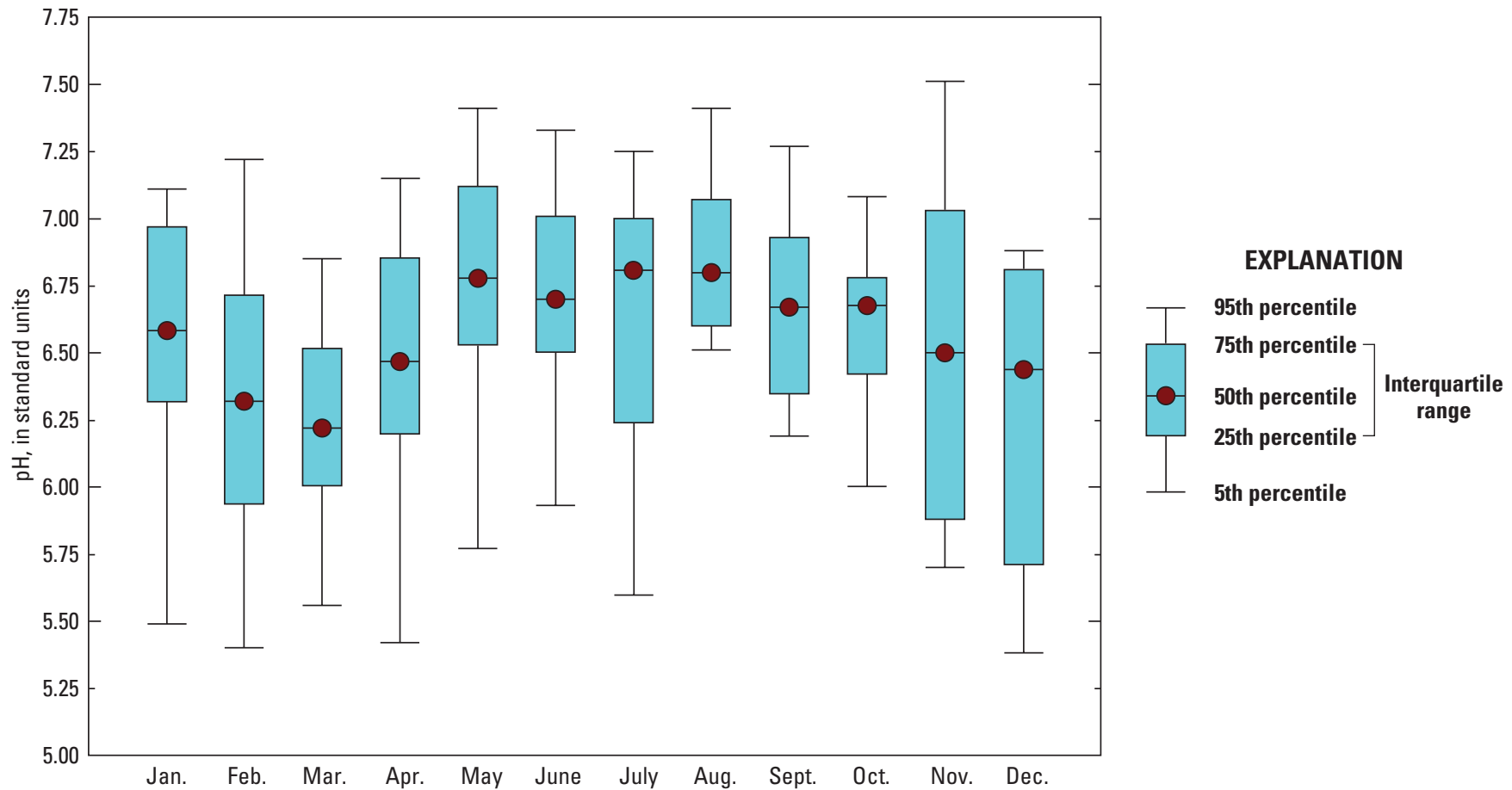

Figure 12. Monthly pH for Flat River tributary (site 1T) in the vicinity of the Treyburn development study area, North Carolina, 1988-2009.

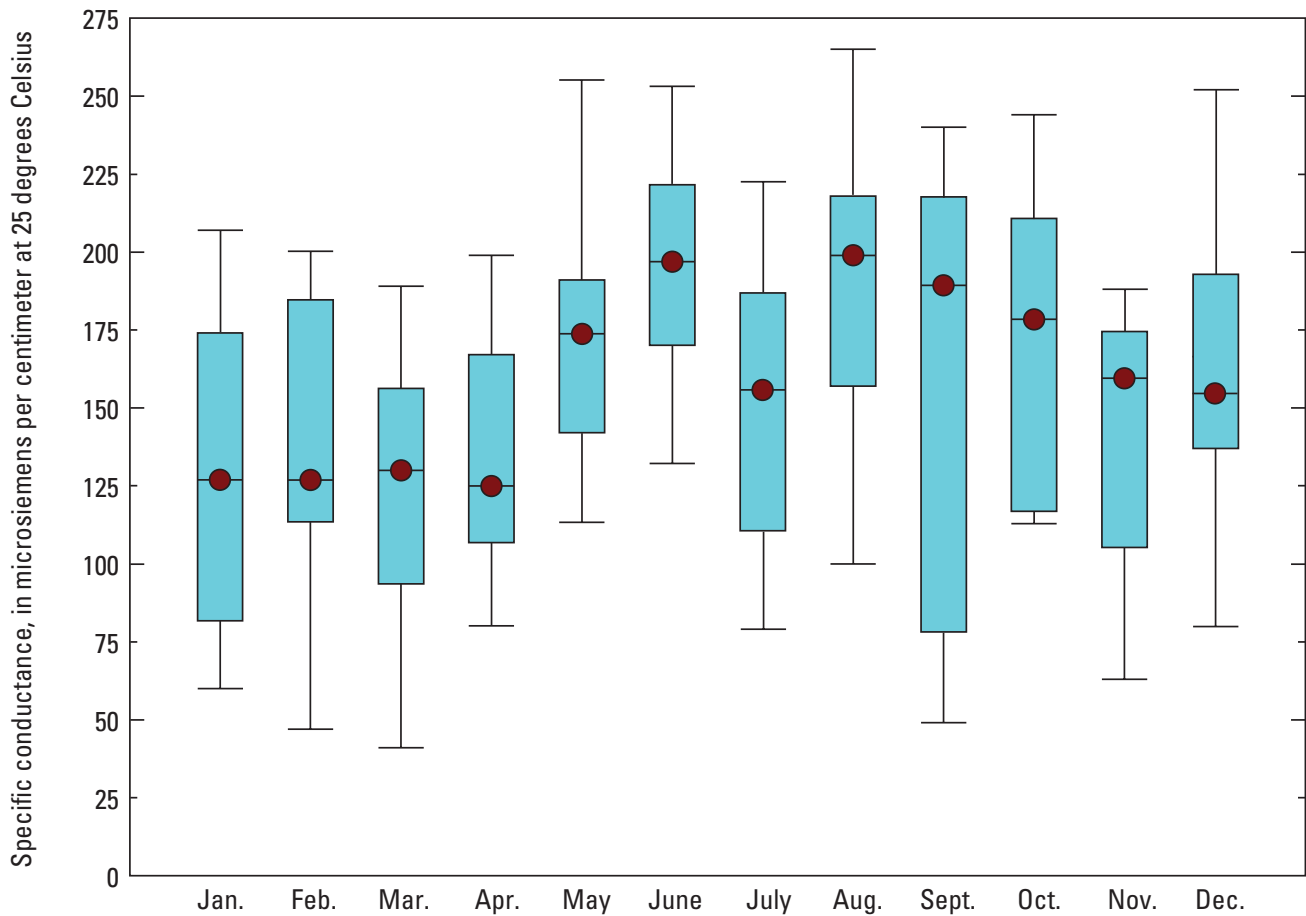

\section{EXPLANATION}

95th percentile

75th percentile

50th percentile Interquartile

25th percentile

5th percentile

Figure 13. Monthly specific conductance for Little River tributary (site 8T), North Carolina, 1994-2009. 

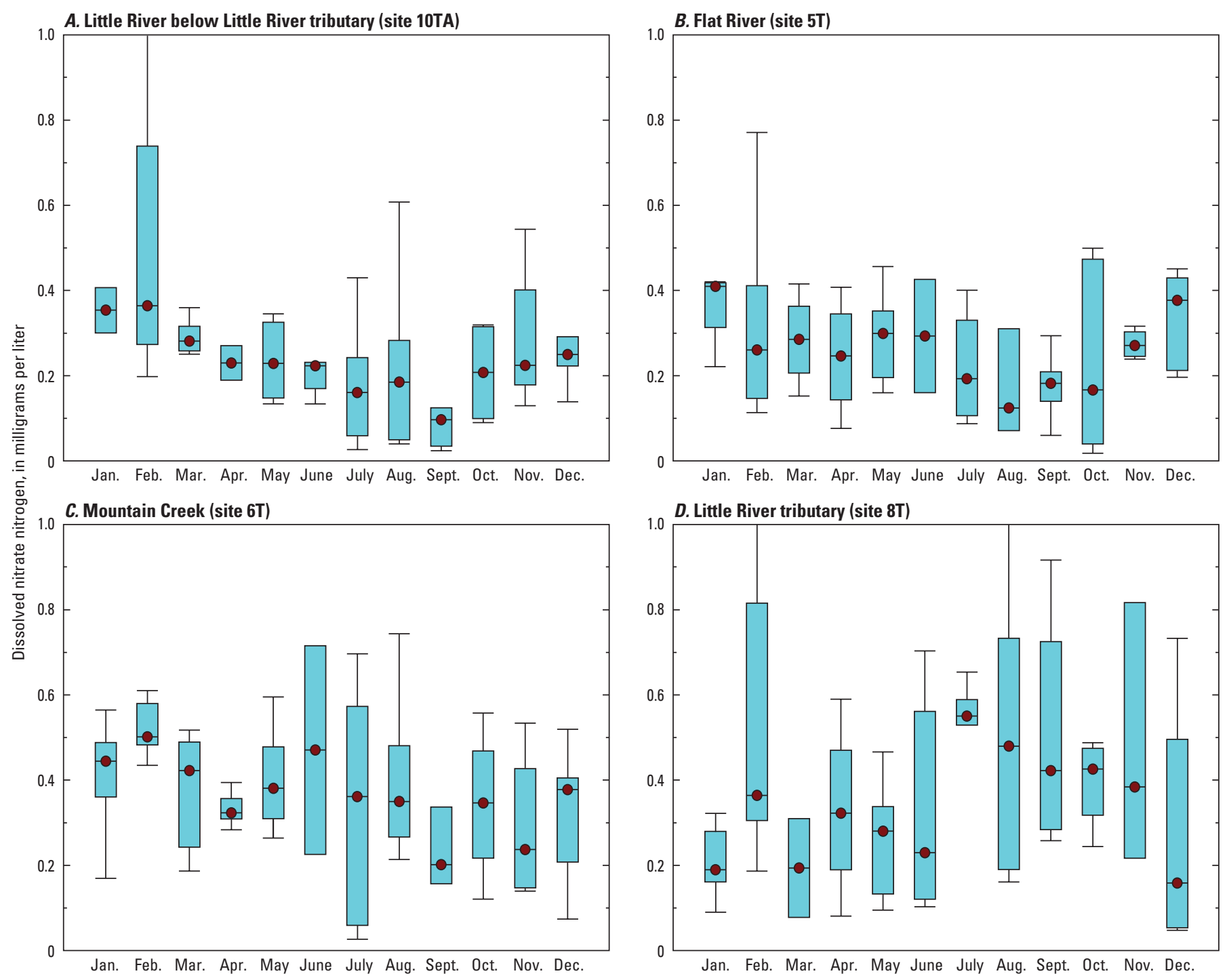

\section{EXPLANATION}

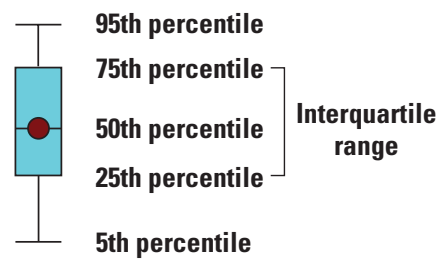

Figure 14. Monthly dissolved nitrate nitrogen for $A$, Little River below Little River tributary (site 10TA), 1994-2009; $B$, Flat River (site 5T), 1988-2009; C, Mountain Creek (site 6T), 1988-2009; and D, Little River tributary (site 8T), 1994-2009, in the Treyburn development study area, North Carolina. 

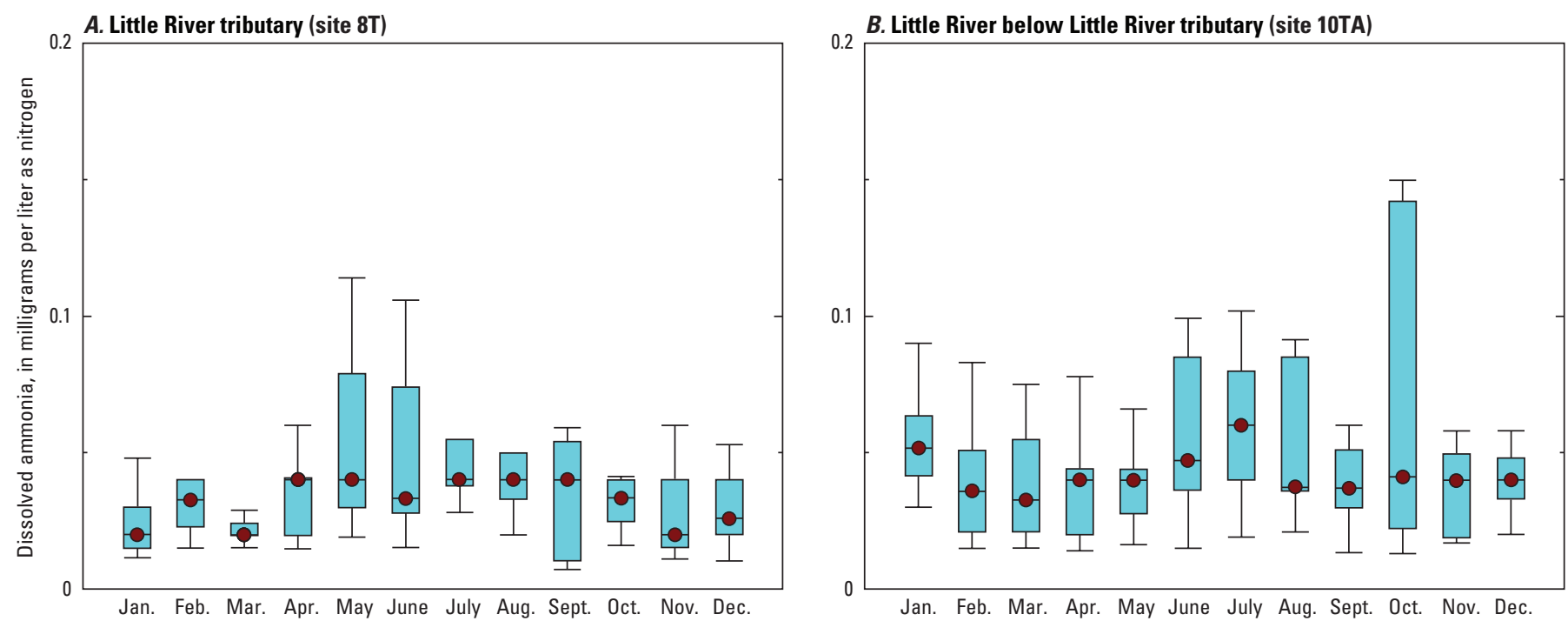

\section{EXPLANATION}

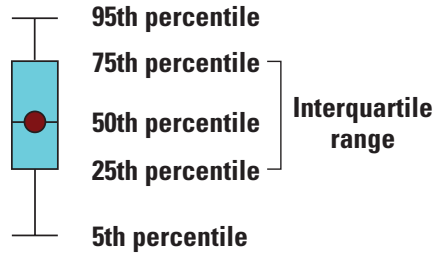

Figure 15. Monthly dissolved ammonia nitrogen for $A$, Little River tributary (site 8T), 1994-2009, and B, Little River below Little River tributary (site 10TA), 1995-2009, in the vicinity of the Treyburn development study area, North Carolina. 


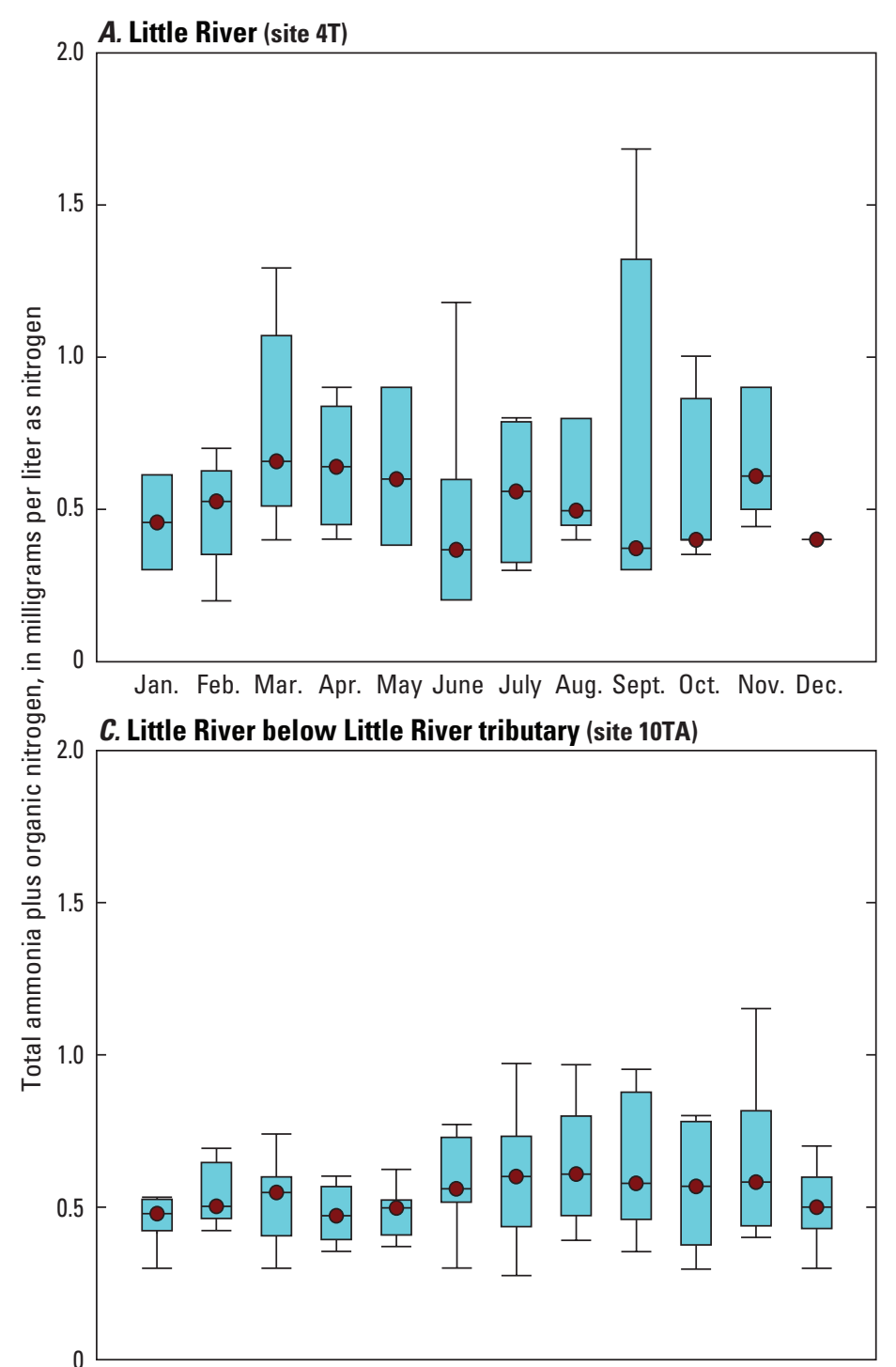

Jan. Feb. Mar. Apr. May June July Aug. Sept. Oct. Nov. Dec.

\section{B. Little River tributary (site 8T)}

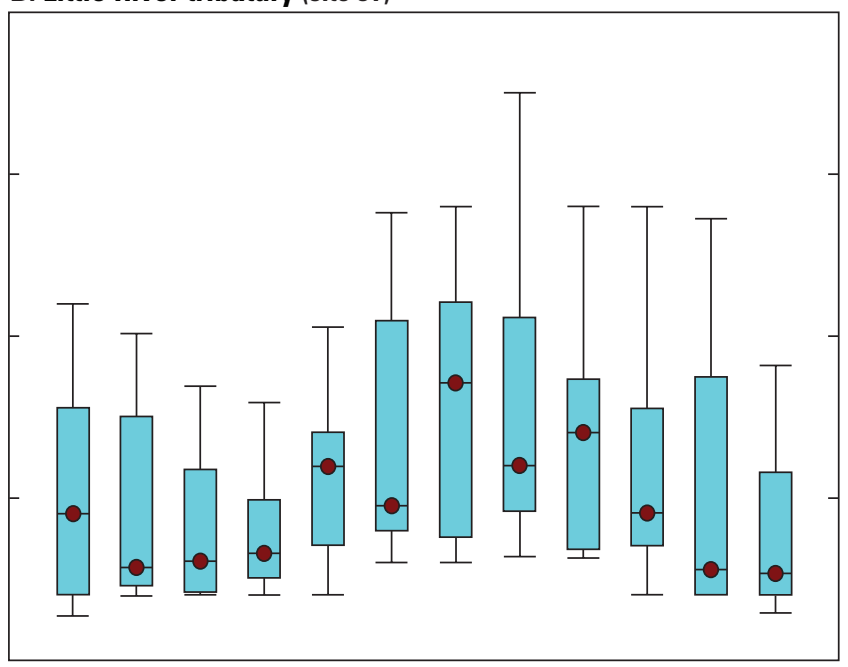

Jan. Feb. Mar. Apr. May June July Aug. Sept. Oct. Nov. Dec.

D. Flat River (site 5T)

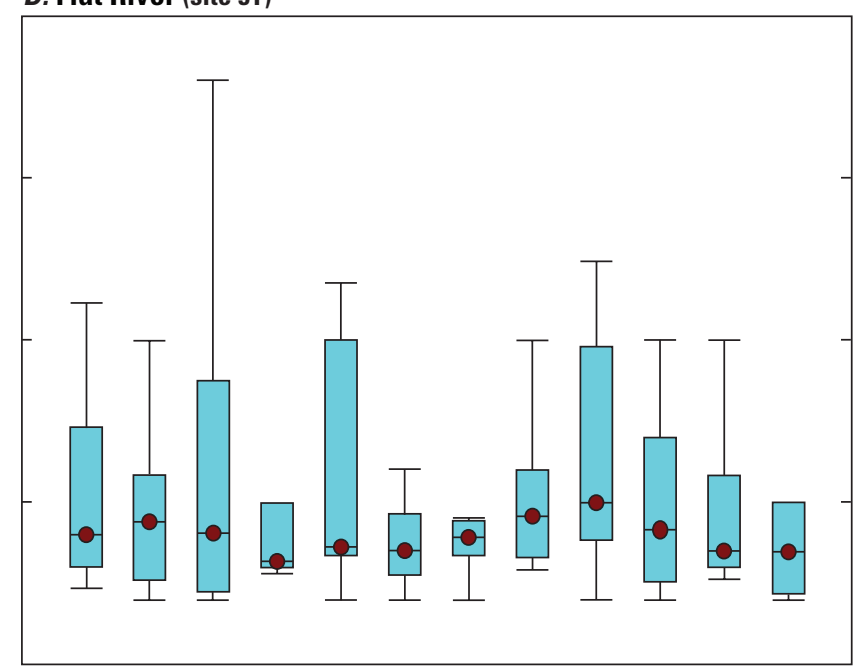

Jan. Feb. Mar. Apr. May June July Aug. Sept. Oct. Nov. Dec.

\section{EXPLANATION}

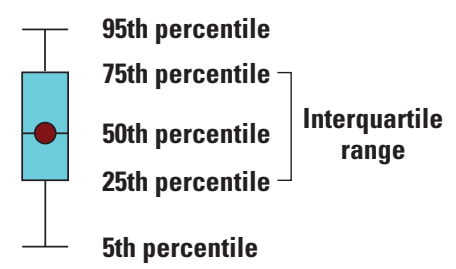

Figure 16. Monthly total ammonia plus organic nitrogen for $A$, Little River (site 4T), 1988-2009; $B$, Little River tributary (site 8T), 1994-2009; C, Little River below Little River tributary (site 10TA), 1995-2009; and D, Flat River (site 5T), 1988-2009, in the vicinity of the Treyburn development study area, North Carolina. 


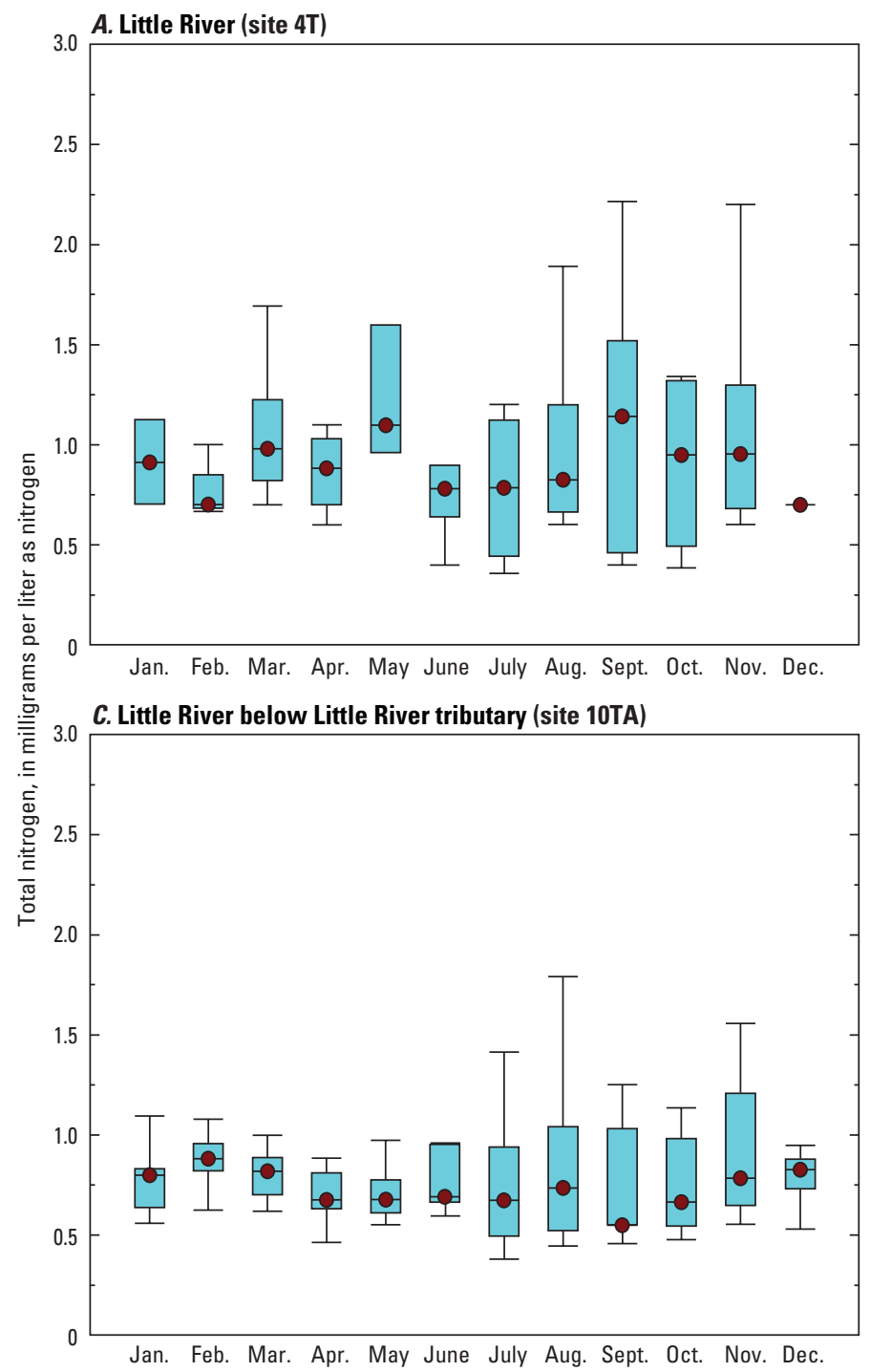

B. Mountain Creek (site 6T)

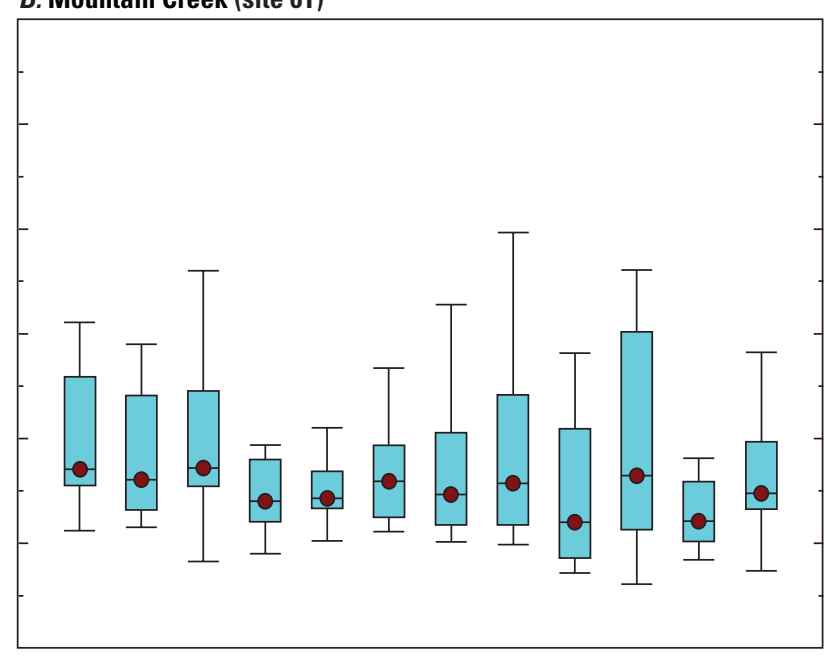

Jan. Feb. Mar. Apr. May June July Aug. Sept. Oct. Nov. Dec.

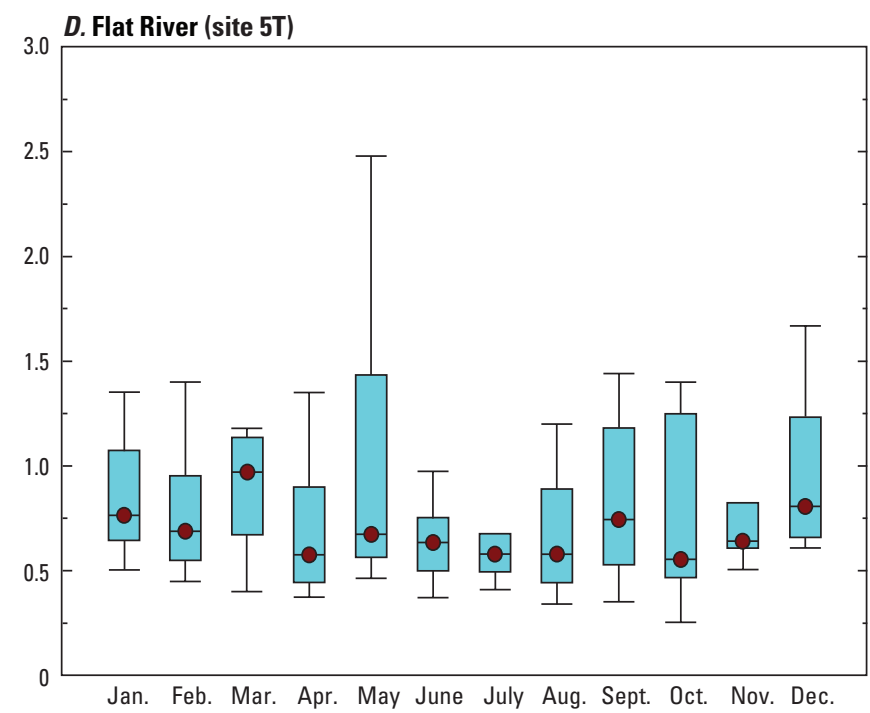

\section{EXPLANATION}

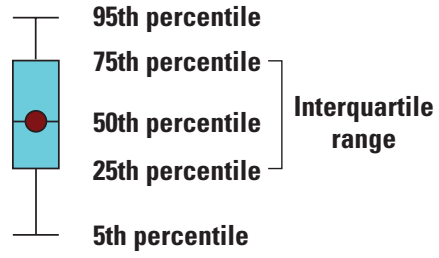

Figure 17. Monthly total nitrogen for $A$, Little River (site 4T), 1988-2009; $B$, Mountain Creek (site 6T),1994-2009; $C$, Little River below Little River tributary (site 10TA), 1995-2009; and D, Flat River (site 5T), 1988-2009, in the vicinity of the Treyburn development study area, North Carolina. 


\section{Phosphorus}

Few distinct seasonal patterns were apparent in monthly distributions of total and dissolved phosphorus concentrations at the study sites. No seasonal effect was evident in dissolved phosphorus concentrations. Orthophosphate concentrations were higher from August to November at Little River (site 4T, fig. 18A) and July through September at Little River tributary (site 8T, fig. 18B). Total phosphorus concentrations were generally higher in March, April, July, and August at Little River (site 4T fig. 19A), July through September at Little River tributary (site 8T, fig. 19B) and Flat River tributary (site 1T, fig. 19D), and July through November at Little River below Little River tributary (site 10TA, fig. 19C). Higher total phosphorus concentrations may be associated with the higher sediment concentrations that tended to occur during the spring and fall. Generally lower overall concentrations at Little River below Little River tributary (site 10TA) may be a result of phosphorus retention in the reservoir upstream from that site. Lower general phosphorus concentrations for the Flat River tributary (site 1T) may be due to the basin being mostly forest.
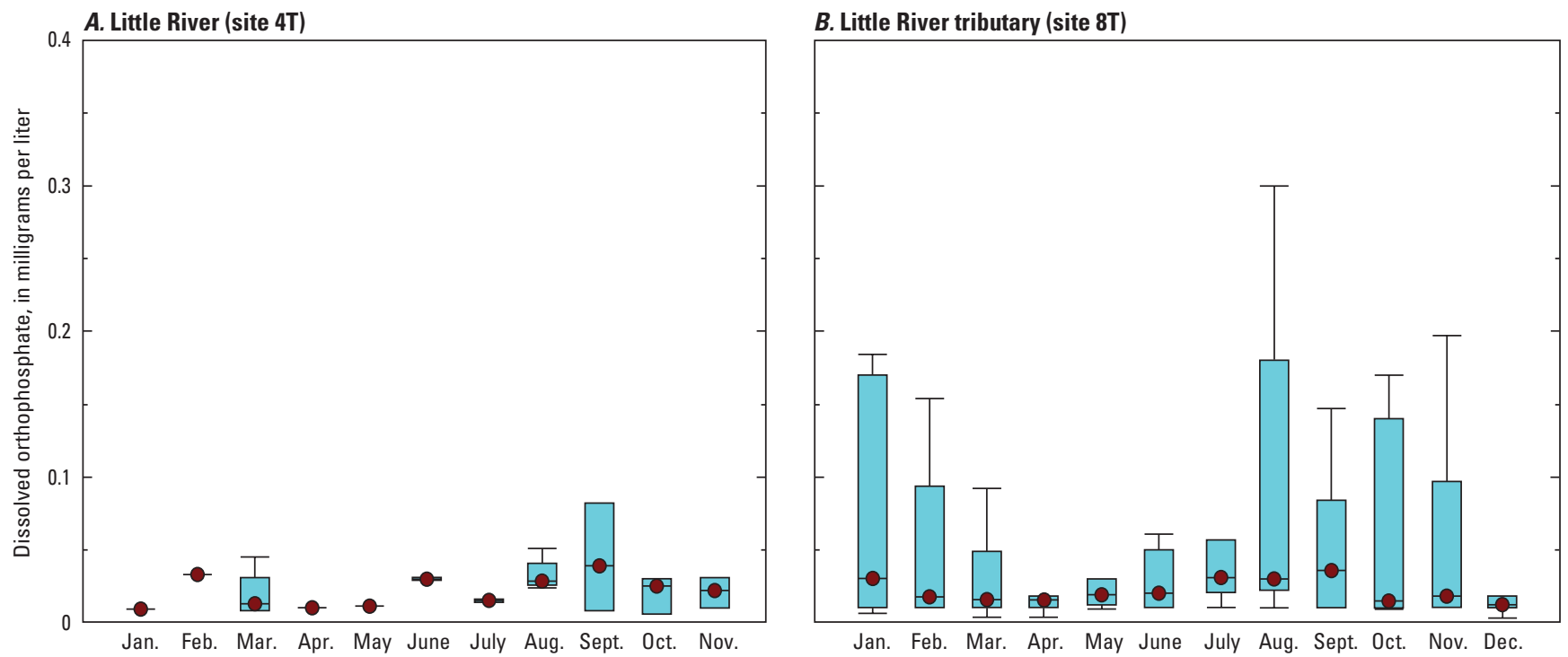

\section{EXPLANATION}

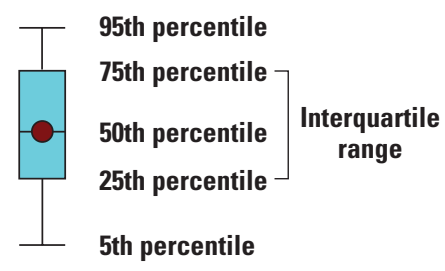

Figure 18. Monthly dissolved orthophosphate for $A$, Little River (site 4T), 1988-2009, and B, Little River tributary (site 8T), 1994-2009, in the vicinity of the Treyburn development study area, North Carolina. 

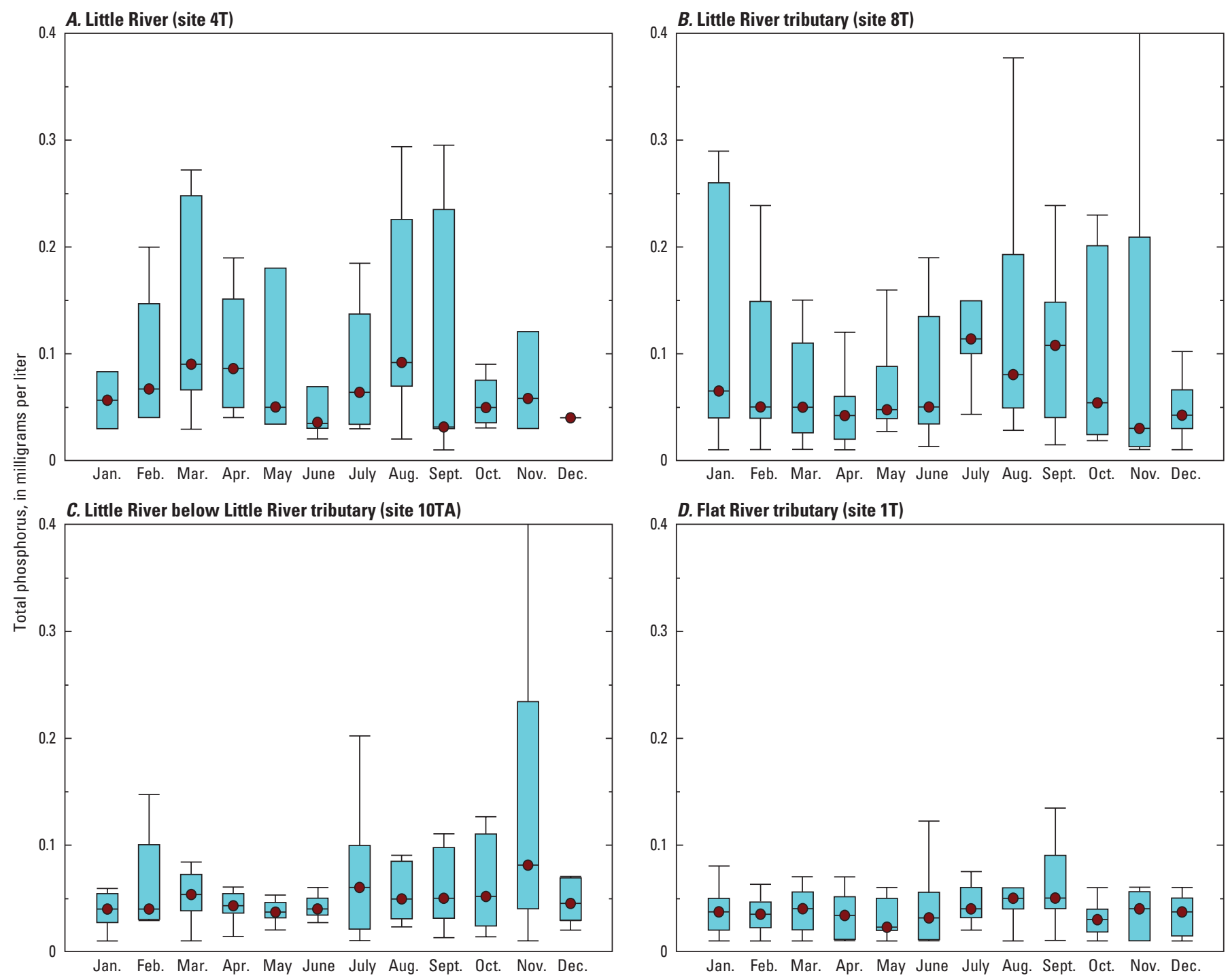

\section{EXPLANATION}

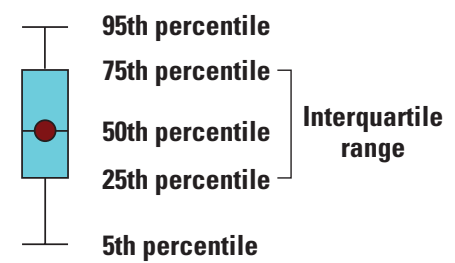

Figure 19. Monthly total phosphorus for $A$, Little River (site 4T), 1988-2009; $B$, Little River tributary (site 8T), 1994-2009; C, Little River below Little River tributary (site 10TA), 1995-2009; and D, Flat River tributary (site 1T), 1988-2009, in the vicinity of the Treyburn development study area, North Carolina. 


\section{Estimation of Nutrient and Sediment Loads and Yields}

Annual instream load estimates from 1988 to 2009 of total nitrogen, dissolved ammonia, total ammonia plus organic nitrogen, dissolved nitrite plus nitrate, total phosphorus, dissolved phosphorus, dissolved orthophosphate, and suspended sediment were calculated using the statistical program S-LOADEST (Runkel and others, 2004). Documentation is contained in the publicly available USGS library for S-PLUS for Windows, release 2.1 (Slack and others, 2003; http://water. usgs.gov/software/library.html). The load estimates were obtained by using the best combination of seven variables in a log-linear regression model based on rankings by the Akaike information criterion (Cohn and others, 1989, 1992; Gilroy and others, 1990) and a review of residuals. The full sevenvariable model is

$$
\begin{aligned}
& \ln \mathrm{L}=a_{0}+a_{1} \ln Q+a_{2}(\ln Q)^{2}+a_{3} t+ \\
& a_{4} t^{2}+a_{5} \sin (2 \pi t)+a_{6} \cos (2 \pi t)+e,
\end{aligned}
$$

where

$$
\begin{aligned}
& \mathrm{L} \quad \text { is } \operatorname{Load}(Q * \mathrm{c}) \text {; } \\
& \text { In is natural logarithm function; } \\
& \text { c is concentration, in milligrams per liter; } \\
& Q \quad \text { is instantaneous discharge at time of } \\
& \text { concentration sampling, in cubic feet per } \\
& \text { second; } \\
& t \text { is time, in decimal years; } \\
& \sin \text { is sine function; } \\
& \cos \text { is cosine function; } \\
& \pi \quad \text { is 3.14169; } \\
& a_{0}, a_{1}, a_{2}, a_{3} \text {, } \\
& a_{4}, a_{5}, a_{6} \text { are coefficients of the regression model } \\
& \left(a_{0}\right. \text { is intercept); and } \\
& e \quad \text { is model error term. }
\end{aligned}
$$

The discharge terms $\left(a_{1} \ln Q\right.$ and $\left.a_{2}(\ln Q)^{2}\right)$ in the model address variability in concentration resulting from discharge variability. The time terms $\left(a_{3} \mathrm{t}\right.$ and $\left.a_{4} t^{2}\right)$ adjust for variability resulting from a linear time trend in concentration, and the sine and cosine terms adjust for seasonal variability in concentration. Bias generated in the estimated load when the load is transformed from log to linear units was corrected using the minimum variance unbiased estimator correction (Bradu and Mundlak, 1970). Censored data were statistically adjusted using the adjusted maximum likelihood estimator (Cohn, 1988).

The models selected by the Akaike information criterion ranking used for load estimation for total nitrogen, dissolved ammonia nitrogen, dissolved nitrite plus nitrate, total ammonia plus organic nitrogen, total phosphorus, dissolved phosphorus, dissolved orthophosphate, and suspended sediment are listed in table 9. Load (tons) was divided by the drainage area (square miles) to estimate yield to allow comparison between basins.

\section{Suspended-Sediment Loads and Yields}

Suspended-sediment load, or the total mass of suspended sediment transported by a stream, is a function of the interaction of physical characteristics of the upstream stream basin, including topographic and physiographic factors, geology, soil characteristics, precipitation, land use, land cover, landmanagement practices, flow, and antecedent conditions of the watershed. Estimation of suspended-sediment yield allows for basin comparisons of sediment delivery and can be used to assess the effectiveness of management actions. Sediment concentrations, loads, and yields are strongly correlated with streamflow so that the greatest loads (and therefore yields) for any period generally are associated with the highest flows. Results from this study are compared to results from analysis by Staub and others (2010) of suspended-sediment yields from 48 basins in the Southeastern United States.

Model statistics and review of residuals indicated a reasonable fit of the models to the data (table 9). The time terms produced by the model give an indication of whether the load has changed with time. One or both of the seasonal terms in the regression model were significant for each site, suggesting strong seasonal variation in suspended-sediment load for all sites.

The annual suspended-sediment loads and yields for the study sites (table 10) show considerable basin-to-basin and year-to-year variation. Up to 23 complete years (1987-2009) of flow data were used in model development. The estimated loads and yields reflect the varying total streamflow from each basin for the years indicated. The highest loads and yields for all sites occurred during water years 1996 and 2003, largely due to high streamflow that occurred during those years (fig. 20). 


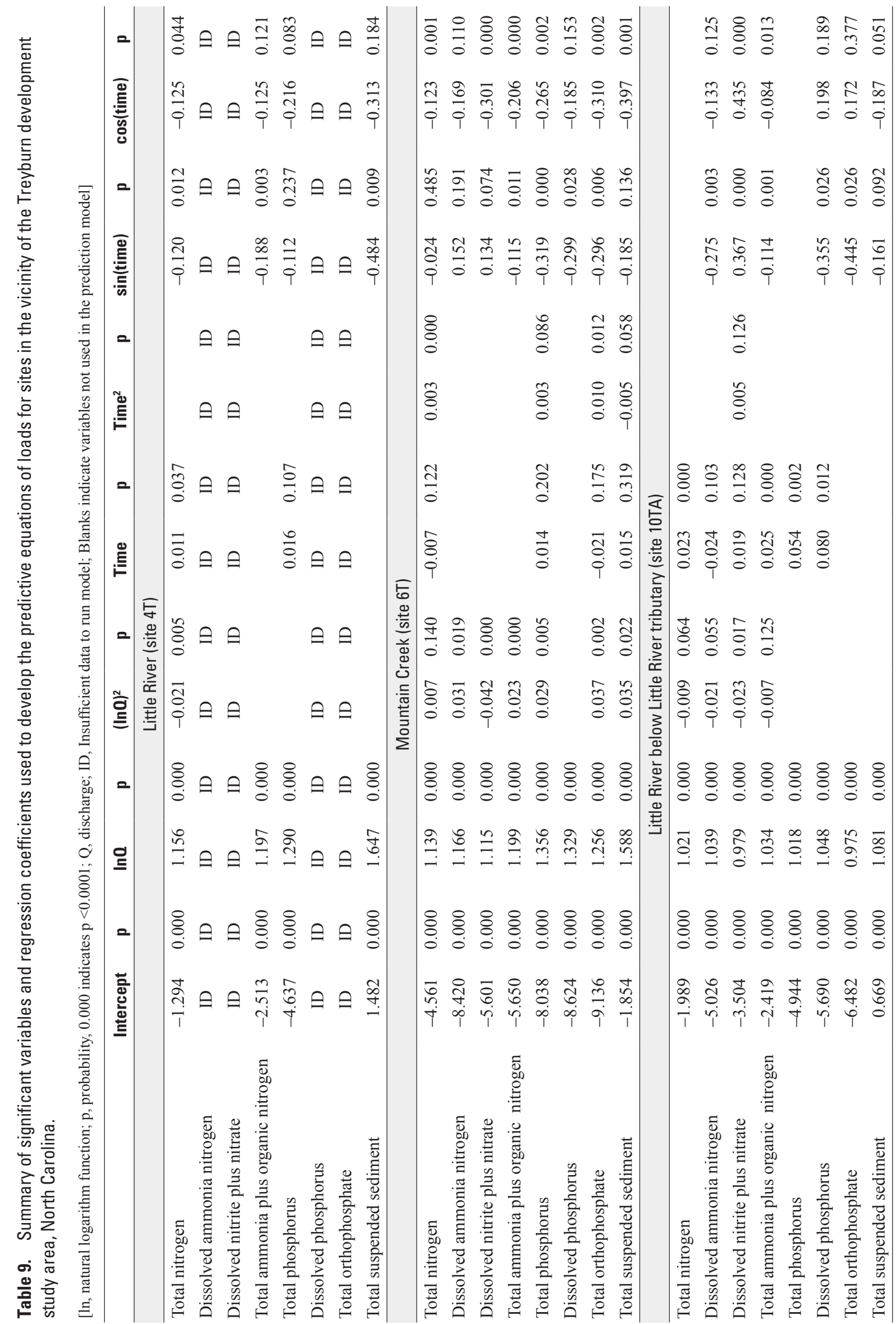




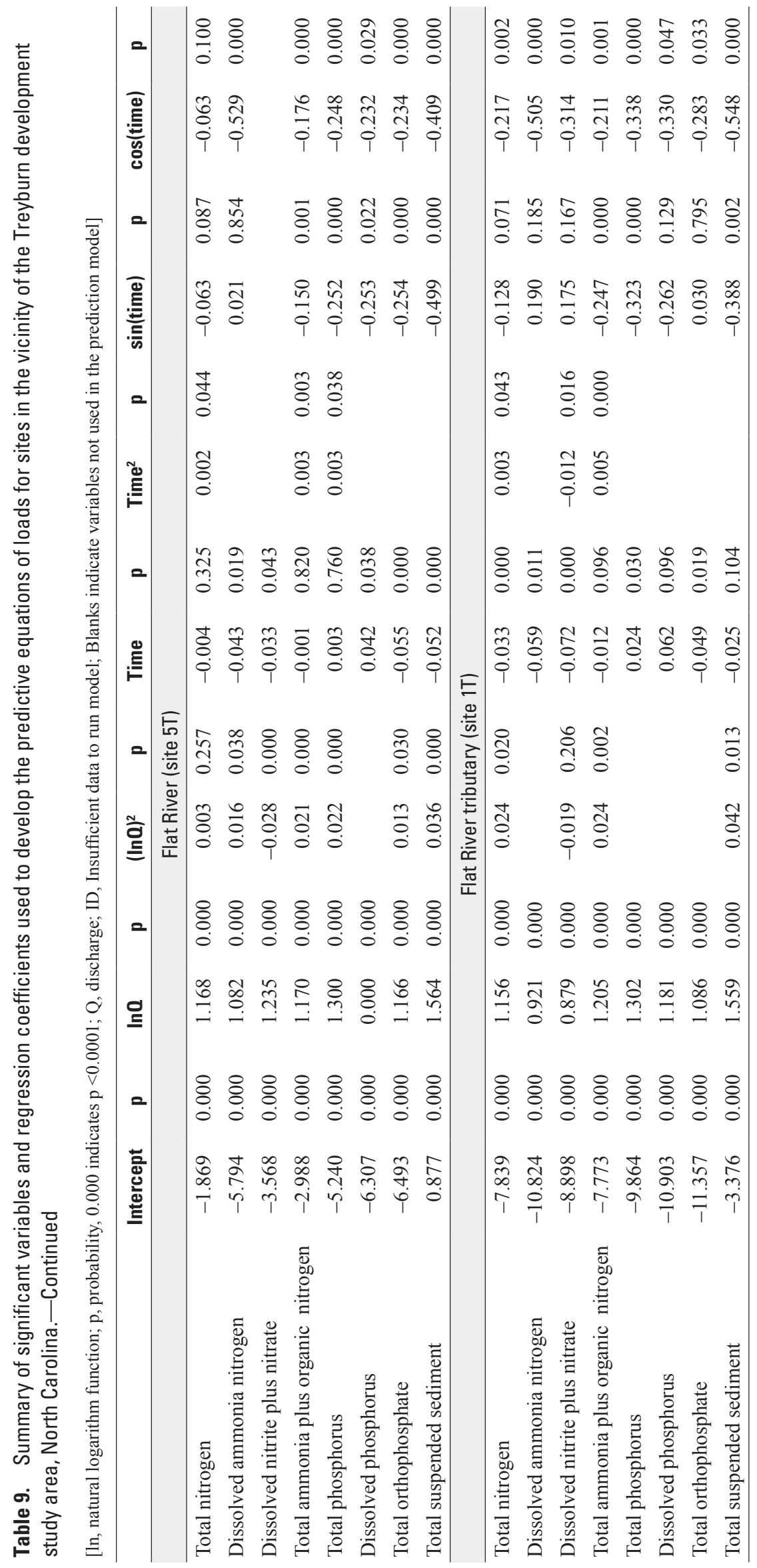


Table 10. Estimated annual suspended-sediment loads and yields for water years 1987-2009 at sites in the vicinity of the Treyburn development study area, North Carolina, including mean and median load and yield for period of record.

[Blanks indicate insufficient data to estimate load and (or) yield]

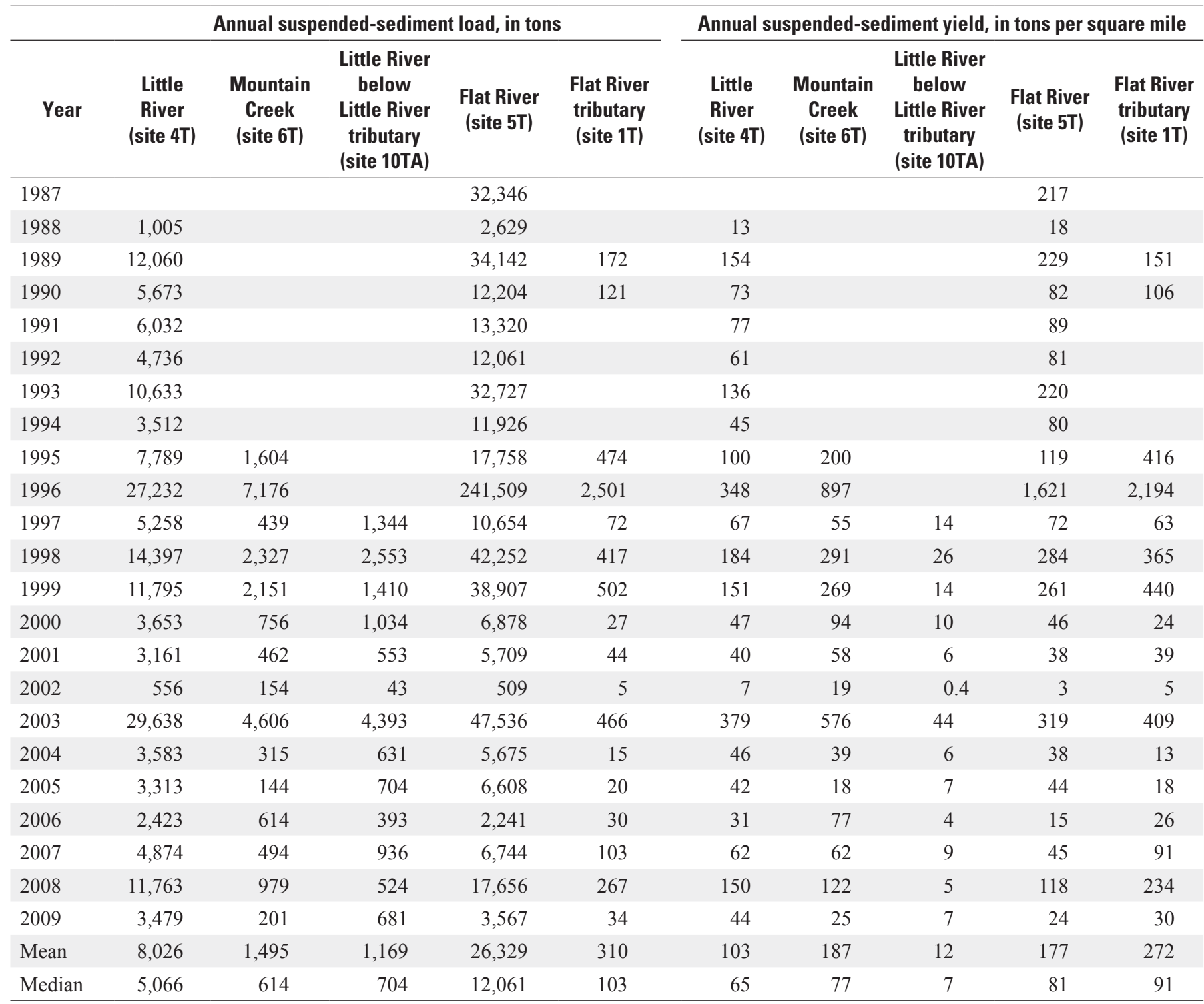




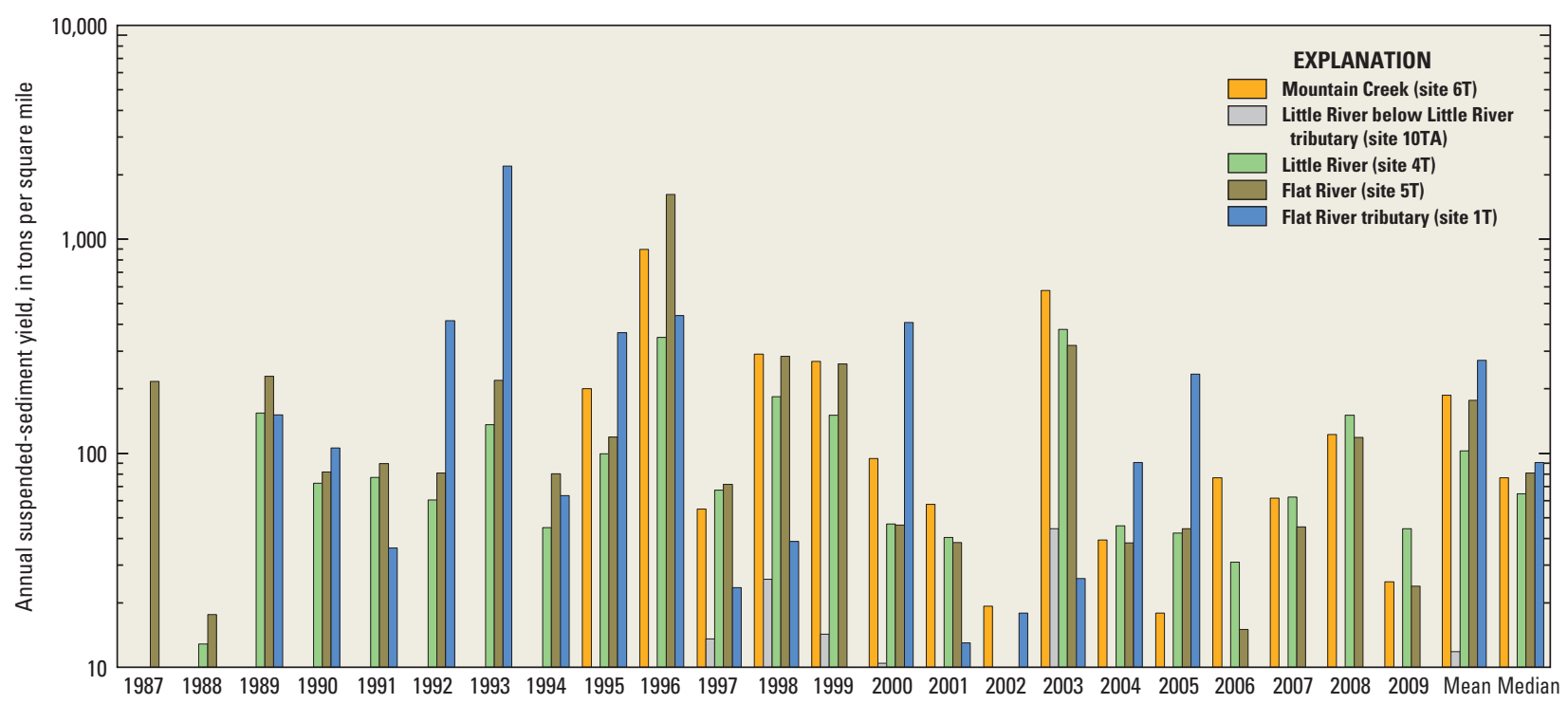

Figure 20. Annual suspended-sediment yields for sites in the vicinity of the Treyburn development study area, North Carolina.

Comparison of sediment yields for the basins indicated that Little River below Little River tributary (site 10TA) had the lowest median yield over the period of record (7 tons per square mile (tons $\left./ \mathrm{mi}^{2}\right)$ ), and Flat River tributary (site 1T) had the largest median yield $\left(91 \mathrm{tons} / \mathrm{mi}^{2}\right)$ during the period of record. The yields estimated for the study sites are low compared to suspended-sediment yields estimated for other basins in the Southeast (1973-2005; Staub and others, 2010). Median suspended-sediment yields for 20 basins in the Southeast ranged from 5.59 to 1,106 tons $/ \mathrm{mi}^{2}$ (Staub and others, 2010). Median yields for the Treyburn sites ranged from 7 to 91 tons $/ \mathrm{mi}^{2}$, which are within the 10th to 65th percentiles of Southeast median suspended-sediment yields (Staub and others, 2010).

\section{Nitrogen Loads and Yields}

Loads and yields were estimated for dissolved nitrite plus nitrate (table 11), dissolved ammonia nitrogen (table 12), total organic plus ammonia nitrogen (Kjeldahl nitrogen, table 13), and total nitrogen (table 14; fig. 21). The multiple-regression models used to estimate nitrogen loads are listed in table 9. Median 1987-2009 period of record nitrogen yields were lowest for Little River below Little River tributary (site 10TA) for dissolved nitrite plus nitrate $\left(0.02\right.$ ton $\left./ \mathrm{mi}^{2}\right)$, total organic plus ammonia nitrogen $\left(0.28 \mathrm{ton} / \mathrm{mi}^{2}\right)$, and total nitrogen $\left(0.42 \mathrm{ton} / \mathrm{mi}^{2}\right)$. Median period of record dissolved ammonia nitrogen yields were lowest for Flat River tributary (site 1T; $0.008 \mathrm{ton} / \mathrm{mi}^{2}$ ). The Flat River had the highest period of record median dissolved nitrate plus nitrite nitrogen yields (site 5T; $0.30 \mathrm{ton} / \mathrm{mi}^{2}$ ). Flat River (site 5T) and Mountain Creek (site 6T) had the highest median dissolved ammonia nitrogen yields ( $0.031 \mathrm{ton} / \mathrm{mi}^{2}$ for both sites). Little River (site $4 \mathrm{~T}$ ) and Mountain Creek (6T) had the highest median total ammonia plus organic nitrogen period of record yields $\left(0.49 \mathrm{ton} / \mathrm{mi}^{2}\right.$ for both sites) and the highest median total nitrogen yields ( 0.81 and 0.78 tons $/ \mathrm{mi}^{2}$, respectively).

The yields estimated for the study sites are low compared to nitrogen yields estimated for other basins in the Southeastern United States (1973-2005). Median dissolved nitrite plus nitrate yields for 48 basins in the Southeast ranged from 0.01 to 16.0 tons $/ \mathrm{mi}^{2}$ (Staub and others, 2010). Median 1987-2009 period of record yields for the study sites ranged from 0.02 to $0.30 \mathrm{ton} / \mathrm{mi}^{2}$, which are within the 13th to 35 th percentiles of yields for nitrite plus nitrate in the Southeast. Median dissolved ammonia yields for 22 basins across the Southeast ranged from 0.01 to 3.01 tons $/ \mathrm{mi}^{2}$ (Staub and others, 2010). Median dissolved ammonia yields for the Treyburn study sites ranged from 0.008 to $0.031 \mathrm{ton} / \mathrm{mi}^{2}$, which are within the 10th to 40th percentiles of yields for dissolved ammonia in the Southeast.

Median total organic plus ammonia nitrogen yields for 47 basins across the Southeast ranged from 0.13 to 34.6 tons $/ \mathrm{mi}^{2}$ (Staub and others, 2010). Median period of record yields for the Treyburn study sites ranged from 0.28 to $0.49 \mathrm{ton} / \mathrm{mi}^{2}$, which are within the range of the 9 th to $38 \mathrm{th}$ percentiles of total organic plus ammonia nitrogen for sites in the Southeast. Median total nitrogen yields for 47 basins across the Southeast ranged from 0.12 to 53.2 tons $/ \mathrm{mi}^{2}$ (Staub and others, 2010). Median total nitrogen yields for the Treyburn study sites ranged from 0.42 to 0.81 ton $/ \mathrm{mi}^{2}$, which are within the range of 7 th to 35 th percentiles of the yields at the Southeastern sites. 
Table 11. Estimated annual nitrate plus nitrite loads and yields for water years 1987-2009 at sites in the vicinity of the Treyburn development study area, North Carolina, including mean and median load and yield for period of record.

[Blanks indicate insufficient data to estimate load and (or) yield]

\begin{tabular}{|c|c|c|c|c|c|c|c|c|c|c|}
\hline \multirow[b]{2}{*}{ Year } & \multicolumn{5}{|c|}{ Annual nitrate plus nitrite load, in tons } & \multicolumn{5}{|c|}{ Annual nitrate plus nitrite yield, in tons per square mile } \\
\hline & $\begin{array}{c}\text { Little } \\
\text { River } \\
\text { (site 4T) }\end{array}$ & $\begin{array}{c}\text { Mountain } \\
\text { Creek } \\
\text { (site 6T) }\end{array}$ & $\begin{array}{l}\text { Little River } \\
\text { below } \\
\text { Little River } \\
\text { tributary } \\
\text { (site 10TA) }\end{array}$ & $\begin{array}{c}\text { Flat River } \\
\text { (site 5T) }\end{array}$ & $\begin{array}{c}\text { Flat River } \\
\text { tributary } \\
\text { (site 1T) }\end{array}$ & $\begin{array}{c}\text { Little } \\
\text { River } \\
\text { (site 4T) }\end{array}$ & $\begin{array}{c}\text { Mountain } \\
\text { Creek } \\
\text { (site 6T) }\end{array}$ & $\begin{array}{l}\text { Little River } \\
\text { below } \\
\text { Little River } \\
\text { tributary } \\
\text { (site 10TA) }\end{array}$ & $\begin{array}{c}\text { Flat River } \\
\text { (site 5T) }\end{array}$ & $\begin{array}{c}\text { Flat River } \\
\text { tributary } \\
\text { (site 1T) }\end{array}$ \\
\hline 1987 & & & & 84.62 & & & & & 0.57 & \\
\hline 1989 & & & & 101.76 & 0.030 & & & & 0.68 & 0.026 \\
\hline 1990 & & & & 67.83 & 0.041 & & & & 0.46 & 0.036 \\
\hline 1991 & & & & 50.20 & & & & & 0.34 & \\
\hline 1992 & & & & 33.94 & & & & & 0.23 & \\
\hline 1993 & & & & 89.89 & & & & & 0.60 & \\
\hline 1997 & & 2.62 & 3.94 & 54.21 & 0.080 & & 0.33 & 0.04 & 0.36 & 0.070 \\
\hline 1998 & & 3.61 & 5.49 & 96.59 & 0.095 & & 0.45 & 0.06 & 0.65 & 0.083 \\
\hline 1999 & & 2.26 & 3.49 & 45.56 & 0.072 & & 0.28 & 0.04 & 0.31 & 0.063 \\
\hline 2000 & & 3.13 & 2.79 & 44.76 & 0.065 & & 0.39 & 0.03 & 0.30 & 0.057 \\
\hline 2001 & & 1.41 & 1.29 & 24.79 & 0.036 & & 0.18 & 0.01 & 0.17 & 0.031 \\
\hline 2002 & & 0.59 & 0.13 & 6.02 & 0.013 & & 0.07 & 0.001 & 0.04 & 0.012 \\
\hline 2003 & & 6.11 & 10.06 & 112.72 & 0.105 & & 0.76 & 0.10 & 0.76 & 0.092 \\
\hline 2004 & & 1.67 & 1.78 & 28.06 & 0.029 & & 0.21 & 0.02 & 0.19 & 0.026 \\
\hline Median & & 2.05 & 1.82 & 44.76 & 0.036 & & 0.26 & 0.02 & 0.30 & 0.031 \\
\hline
\end{tabular}


Table 12. Estimated annual ammonia nitrogen loads and yields for water years 1987-2009 at sites in the vicinity of the Treyburn development study area, North Carolina, including mean and median load and yield for period of record.

[Blanks indicate insufficient data to estimate load and (or) yield]

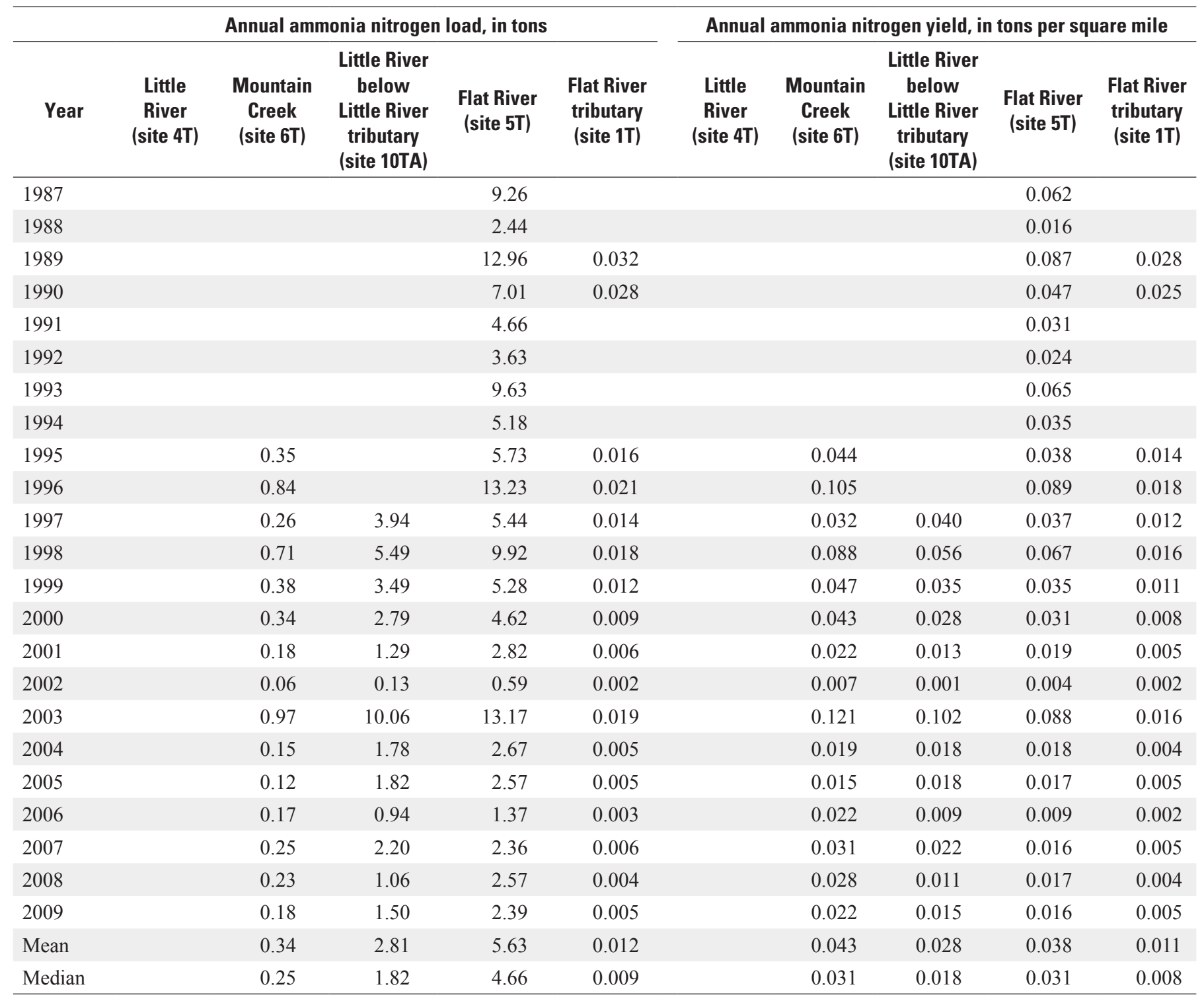


Table 13. Estimated annual total ammonia plus organic nitrogen loads and yields for water years 1987-2009 at sites in the vicinity of the Treyburn development study area, North Carolina, including mean and median load and yield for period of record.

[Blanks indicate insufficient data to estimate load and (or) yield]

\begin{tabular}{|c|c|c|c|c|c|c|c|c|c|c|}
\hline \multirow[b]{2}{*}{ Year } & \multicolumn{5}{|c|}{ Annual total Kjeldahl nitrogen load, in tons } & \multicolumn{5}{|c|}{ Annual total Kjeldahl nitrogen yield, in tons per square mile } \\
\hline & $\begin{array}{c}\text { Little } \\
\text { River } \\
\text { (site 4T) }\end{array}$ & $\begin{array}{l}\text { Mountain } \\
\text { Creek } \\
\text { (site 6T) }\end{array}$ & $\begin{array}{c}\text { Little River } \\
\text { below } \\
\text { Little River } \\
\text { tributary } \\
\text { (site 10TA) }\end{array}$ & $\begin{array}{c}\text { Flat River } \\
\text { (site 5T) }\end{array}$ & $\begin{array}{c}\text { Flat River } \\
\text { tributary } \\
\text { (site 1T) }\end{array}$ & $\begin{array}{c}\text { Little } \\
\text { River } \\
\text { (site 4T) }\end{array}$ & $\begin{array}{c}\text { Mountain } \\
\text { Creek } \\
\text { (site 6T) }\end{array}$ & $\begin{array}{c}\text { Little River } \\
\text { below } \\
\text { Little River } \\
\text { tributary } \\
\text { (site 10TA) }\end{array}$ & $\begin{array}{c}\text { Flat River } \\
\text { (site 5T) }\end{array}$ & $\begin{array}{c}\text { Flat River } \\
\text { tributary } \\
\text { (site 1T) }\end{array}$ \\
\hline 1987 & & & & 93.98 & & & & & 0.63 & \\
\hline 1989 & 75.95 & & & 126.51 & 0.72 & 0.97 & & & 0.85 & 0.63 \\
\hline 1990 & 54.72 & & & 79.45 & 0.67 & 0.70 & & & 0.53 & 0.59 \\
\hline 1991 & 46.40 & & & 62.10 & & 0.59 & & & 0.42 & \\
\hline 1992 & 30.98 & & & 45.51 & & 0.40 & & & 0.31 & \\
\hline 1993 & 69.92 & & & 121.94 & & 0.89 & & & 0.82 & \\
\hline 1997 & 49.15 & 3.93 & 39.46 & 81.59 & 0.30 & 0.63 & 0.49 & 0.40 & 0.55 & 0.26 \\
\hline 1998 & 82.58 & 9.66 & 69.44 & 159.66 & 0.78 & 1.06 & 1.21 & 0.70 & 1.07 & 0.69 \\
\hline 1999 & 46.14 & 7.28 & 37.29 & 95.66 & 0.75 & 0.59 & 0.91 & 0.38 & 0.64 & 0.66 \\
\hline 2000 & 39.50 & 5.05 & 33.11 & 75.33 & 0.18 & 0.51 & 0.63 & 0.33 & 0.51 & 0.16 \\
\hline 2001 & 27.49 & 2.55 & 16.62 & 44.82 & 0.15 & 0.35 & 0.32 & 0.17 & 0.30 & 0.14 \\
\hline 2002 & 7.21 & 1.03 & 1.69 & 10.60 & 0.04 & 0.09 & 0.13 & 0.02 & 0.07 & 0.03 \\
\hline 2003 & 154.08 & 16.06 & 135.71 & 242.47 & 1.01 & 1.97 & 2.01 & 1.37 & 1.63 & 0.89 \\
\hline 2004 & 35.16 & 2.64 & 22.90 & 58.54 & 0.12 & 0.45 & 0.33 & 0.23 & 0.39 & 0.10 \\
\hline Median & 38.07 & 3.93 & 27.46 & 67.27 & 0.39 & 0.49 & 0.49 & 0.28 & 0.45 & 0.35 \\
\hline
\end{tabular}


Table 14. Estimated annual total nitrogen loads and yields for water years 1987-2009 at sites in the vicinity of the Treyburn development study area, North Carolina, including mean and median load and yield for period of record.

[Blanks indicate insufficient data to estimate load and (or) yield]

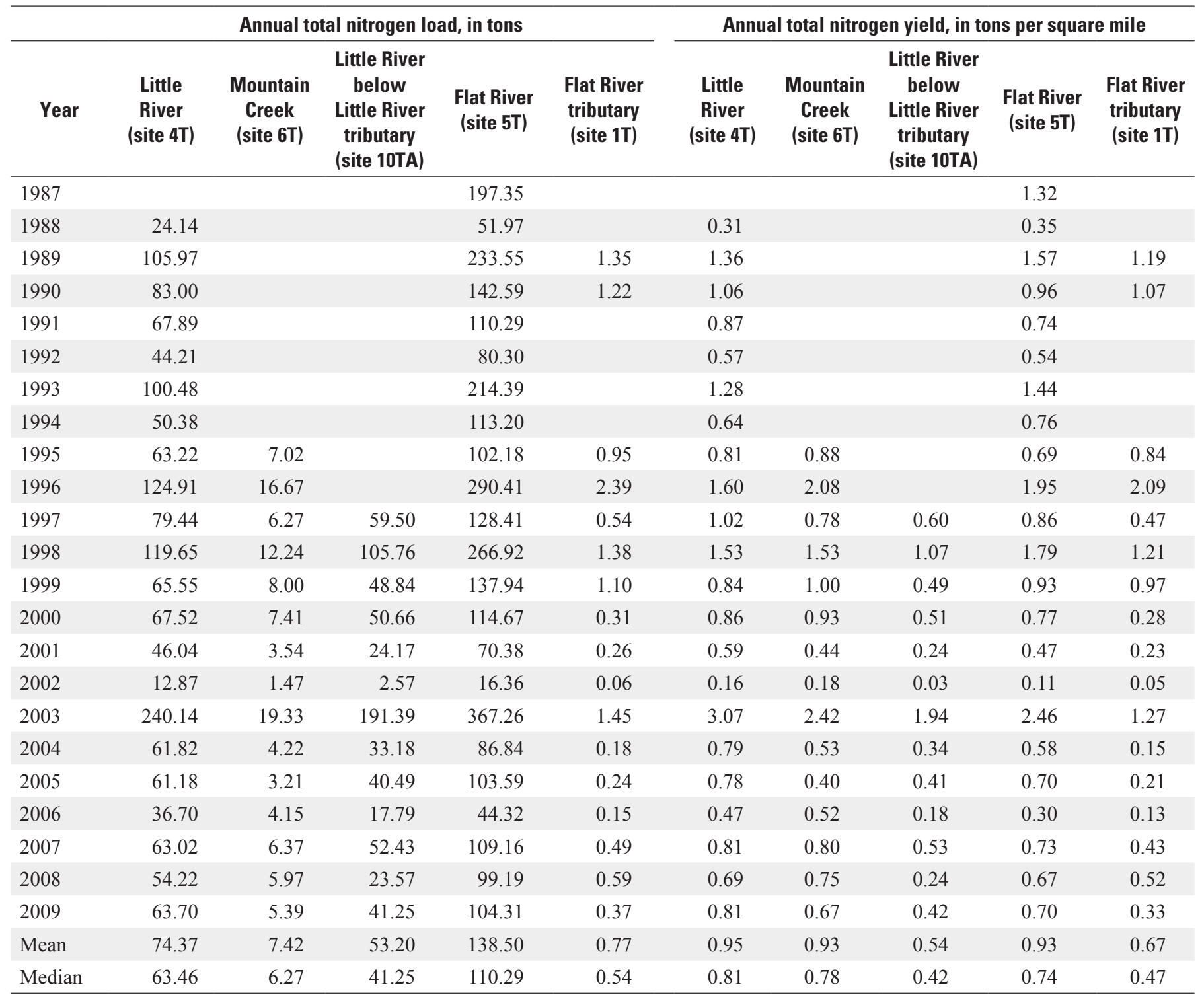




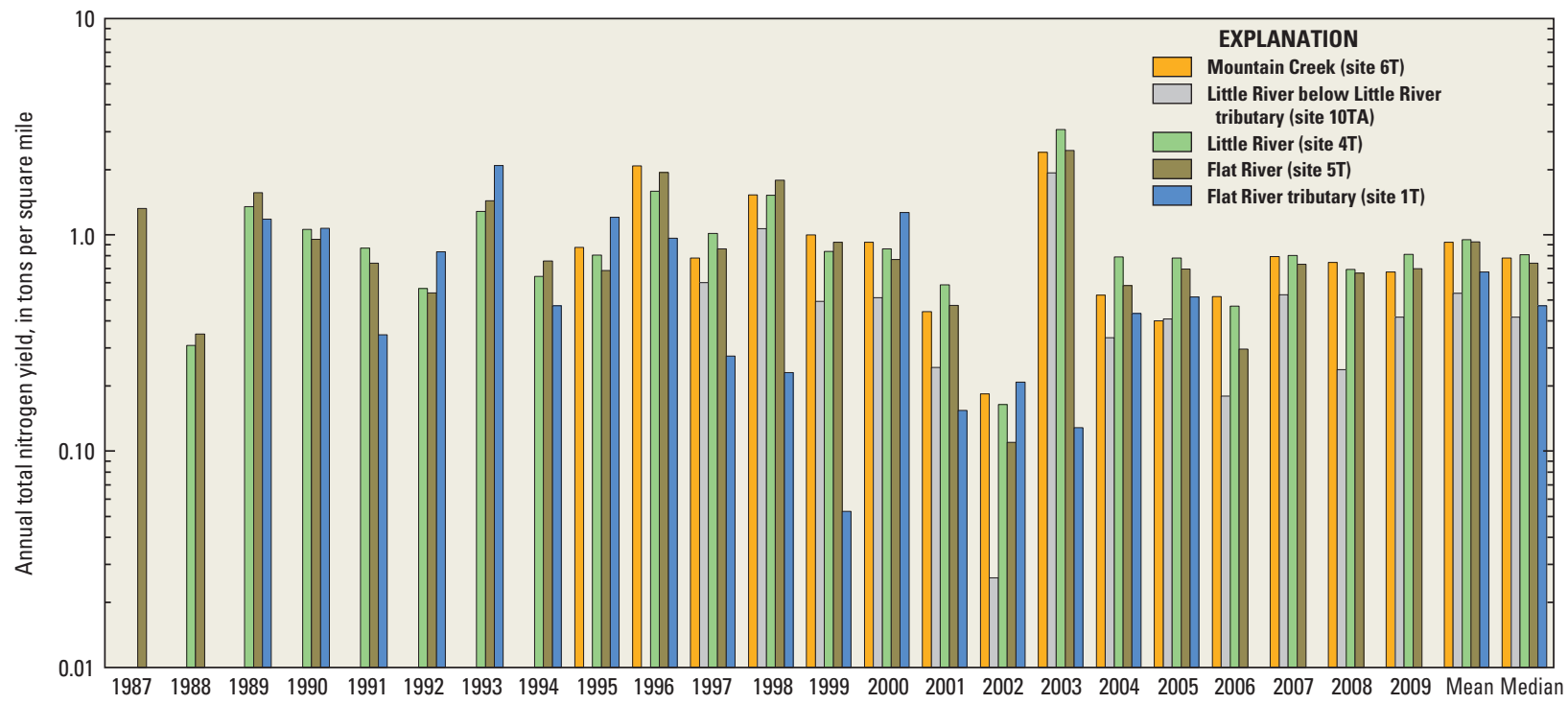

Figure 21. Annual total nitrogen yields for sites in the vicinity of the Treyburn development study area, North Carolina.

\section{Phosphorus Loads and Yields}

Loads and yields were estimated for dissolved orthophosphorus (table 15), dissolved phosphorus, (table 16), and total phosphorus (table 17; fig. 22). The multiple-regression models used to estimate phosphorus loads are provided in table 9. Median period of record yields were lowest for Flat River tributary (site $1 \mathrm{~T})$ dissolved phosphorus $\left(0.010\right.$ ton $\left./ \mathrm{mi}^{2}\right)$ and dissolved orthophosphorus $\left(0.005 \mathrm{ton} / \mathrm{mi}^{2}\right)$ and for Little River (site 10TA) total phosphorus $\left(0.04\right.$ ton $\left./ \mathrm{mi}^{2}\right)$. Mountain Creek (site 6T) had the highest median period of record total phosphorus yields $\left(0.10 \mathrm{ton} / \mathrm{mi}^{2}\right)$, dissolved phosphorus yields $\left(0.03 \mathrm{ton} / \mathrm{mi}^{2}\right)$, and dissolved orthophosphorus yields (0.02 ton $\left./ \mathrm{mi}^{2}\right)$.

The 1987-2009 period of record annual median phosphorus yields estimated for the study sites are low compared to phosphorus yields estimated for other basins in the Southeast (1973-2005). Median dissolved orthophosphorus yields for the study sites ranged from 0.005 to $0.02 \mathrm{ton} / \mathrm{mi}^{2}$. Dissolved orthophosphate yields for 22 basins across the Southeast ranged from medians of 0.004 to 1.37 tons $/ \mathrm{m}^{2}$ (Staub and others, 2010). The study sites fall in the range of the 7 th to 27th percentiles of yields for dissolved orthophosphate in the Southeast. Total phosphorus yields for 47 basins across the Southeast ranged from medians of 0.005 to 5.64 tons $/ \mathrm{mi}^{2}$ (Staub and others, 2010). Median annual total phosphorus yields for the study sites ranged from 0.04 to $0.10 \mathrm{ton} / \mathrm{mi}^{2}$, which fall in the range of the 18th to 40th percentiles of Southeastern yields. 
Table 15. Estimated annual dissolved orthophosphorus loads and yields for water years 1987-2009 at sites in the vicinity of the Treyburn development study area.

[Blanks indicate insufficient data to estimate load and (or) yield]

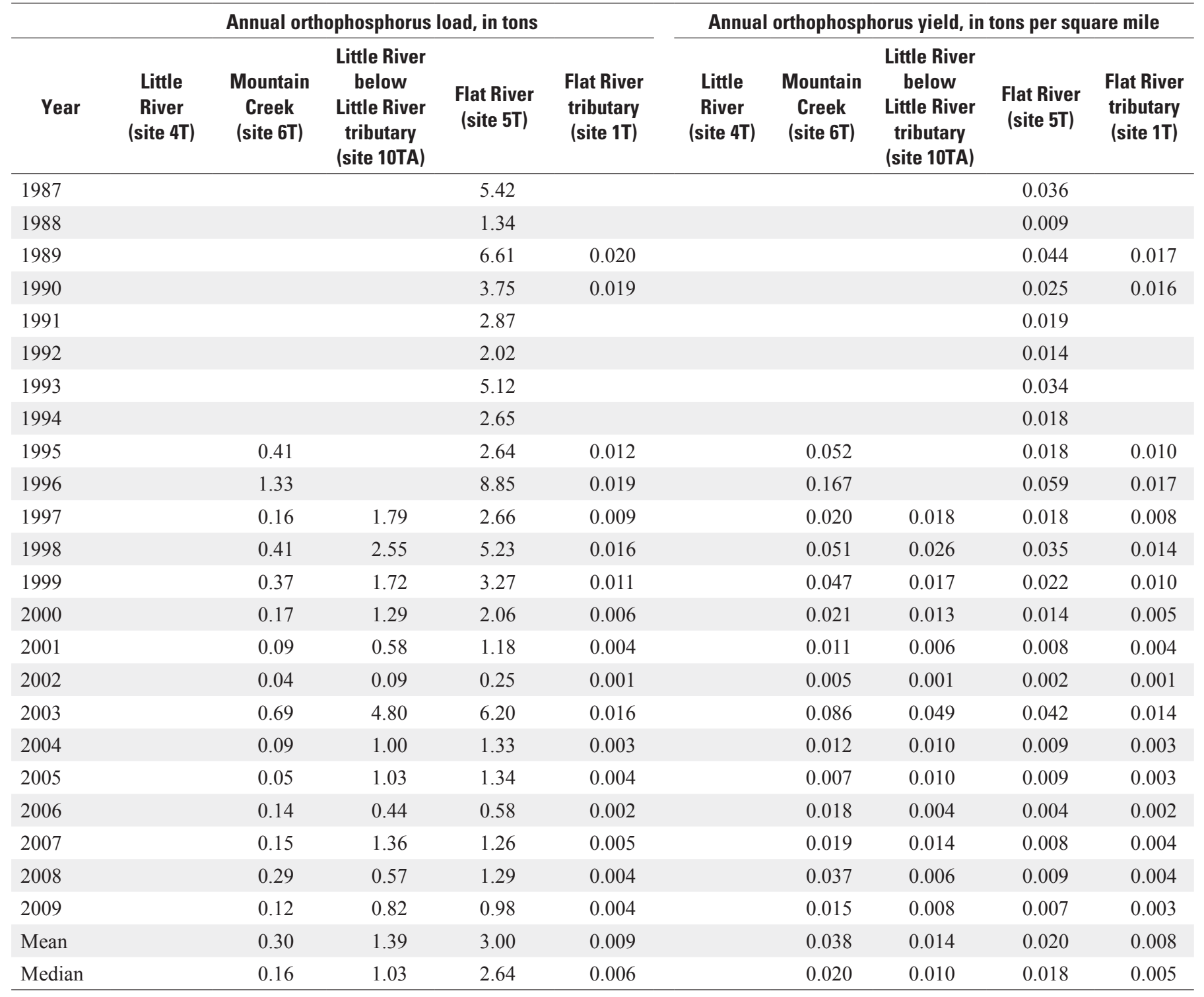


Table 16. Estimated annual dissolved phosphorus loads and yields for water years 1987-2009 at sites in the vicinity of the Treyburn development study area, North Carolina, including mean and median load and yield for period of record.

[Blanks indicate insufficient data to estimate load and (or) yield]

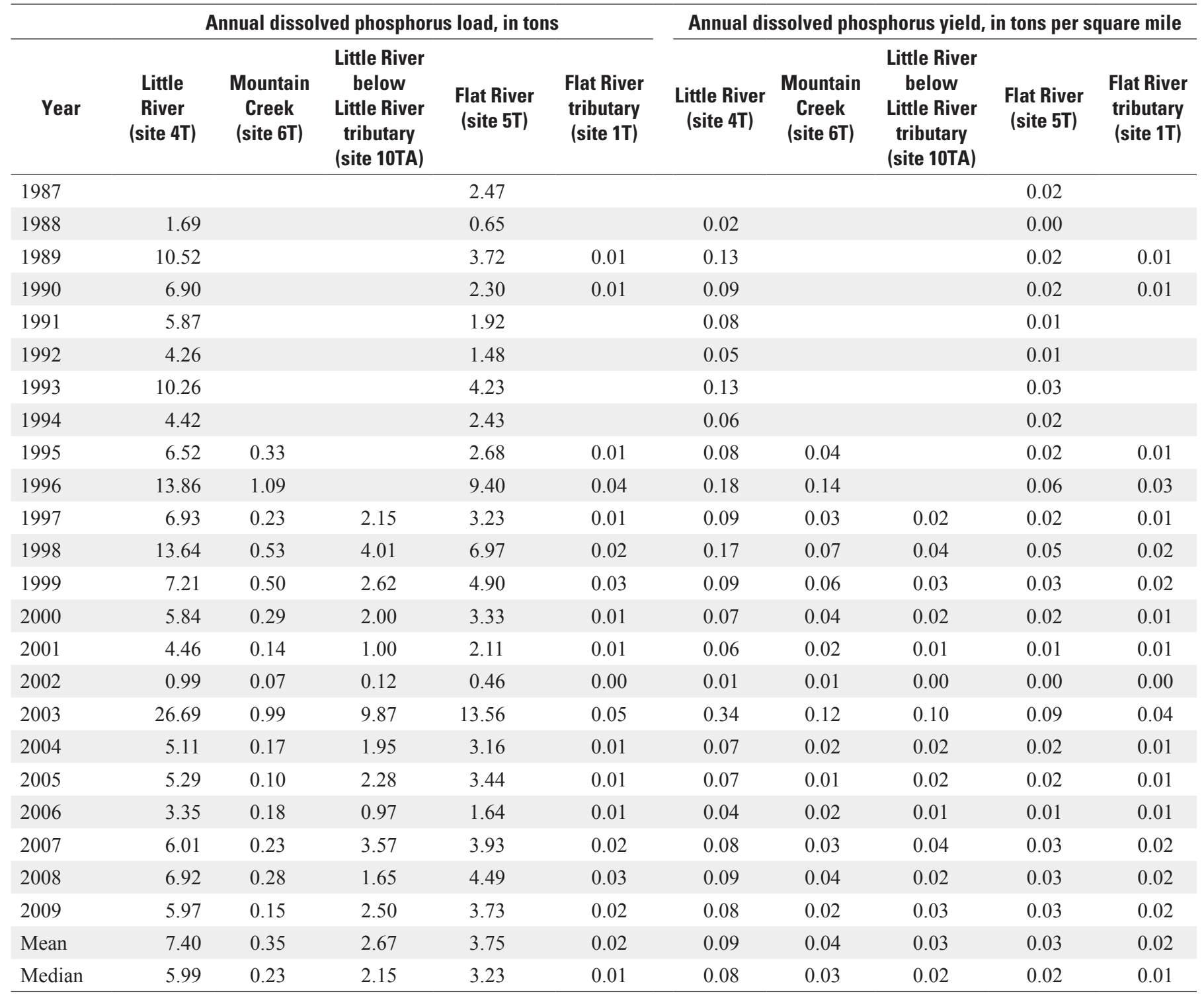


Table 17. Estimated annual total phosphorus loads and yields for water years 1987-2009 at sites in the vicinity of the Treyburn development study area, North Carolina, including mean and median load and yield for period of record.

[Blanks indicate insufficient data to estimate load and (or) yield]

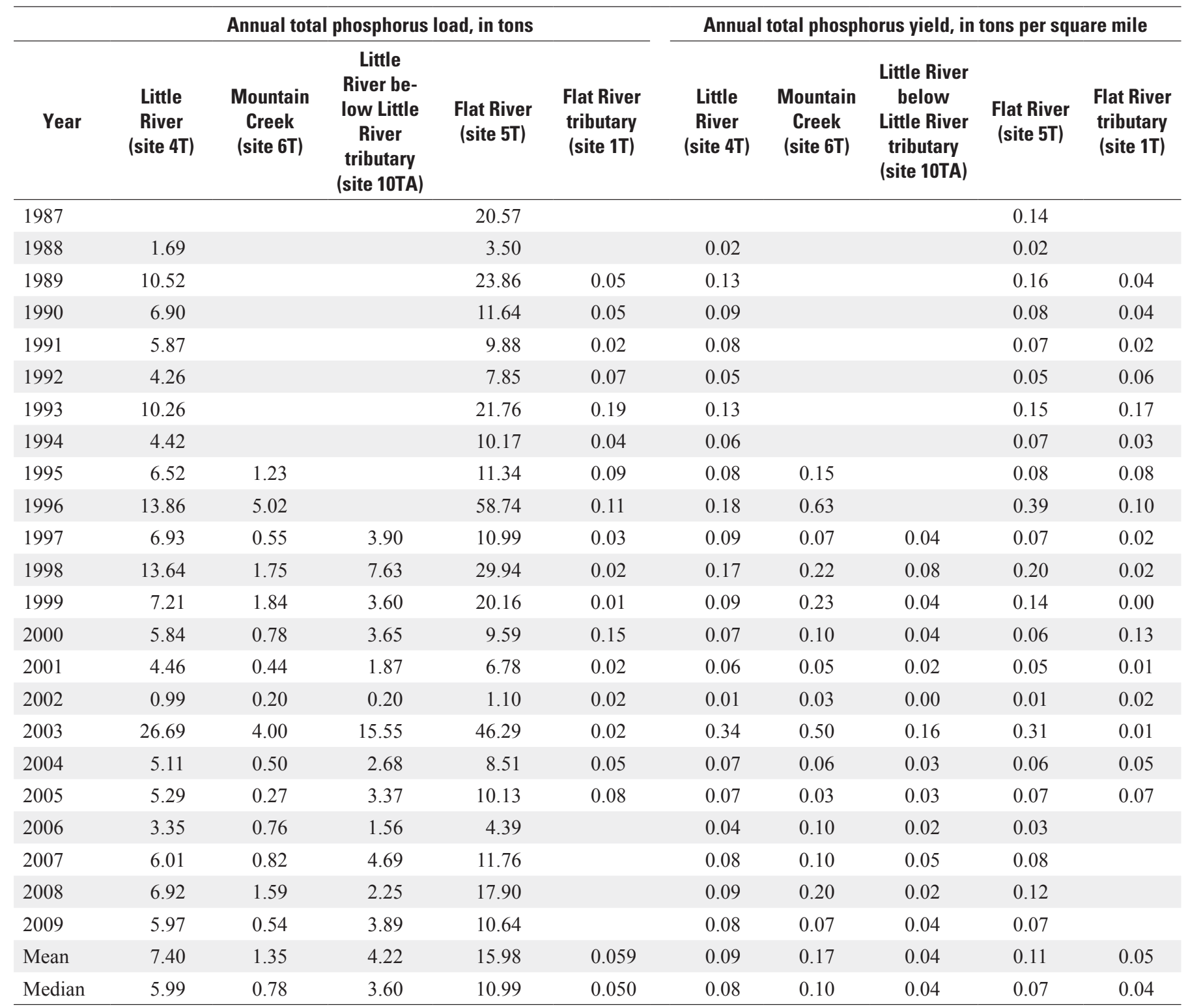




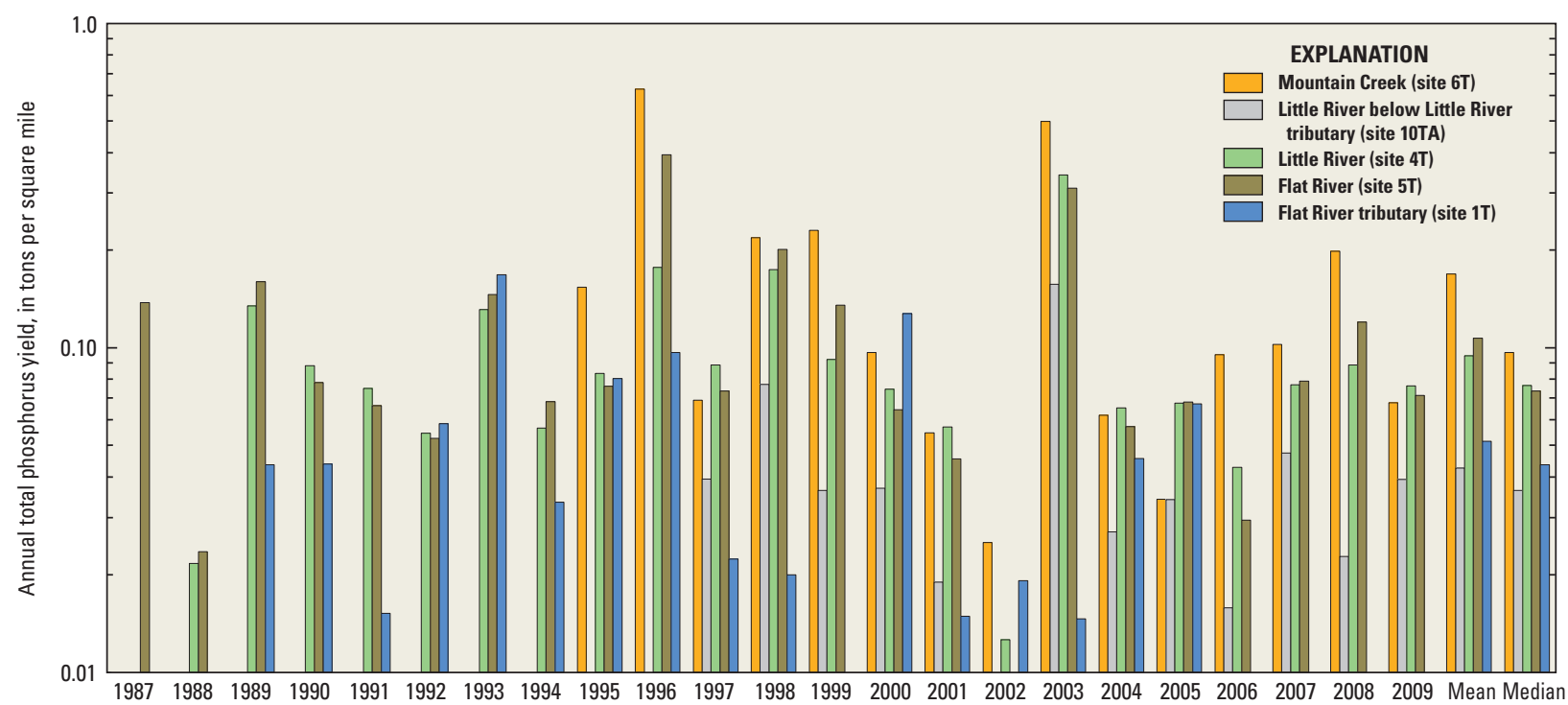

Figure 22. Annual total phosphorus yields for sites in the vicinity of the Treyburn development study area, North Carolina.

\section{Trend Analysis}

Statistical trends in water-quality data collected at the stream sites flowing in or near the Treyburn development were evaluated to determine the extent to which land-use conversion has affected water quality at these sites. Data used to characterize water-quality trends were collected from October 1988 through September 2009.

\section{Methodology}

The Seasonal Kendall test described by Hirsch and others (1982) was used for trend analysis (see also Crawford and others 1983; Schertz and Hirsch 1985; and Helsel, 1993). The Seasonal Kendall test is a nonparametric or distribution-free procedure developed to detect monotonically (one direction) increasing or decreasing trends over time in water-quality data that show seasonality. The Seasonal Kendall test adjusts for seasonal variability by comparing seasonally grouped constituent concentrations and adjusts for the effects of streamflow with locally weighted scatterplot smoothing (LOESS) curves. The Seasonal Kendall test examines pairs of values over time, assigning a plus if an increase occurs from one value to the next, or a minus if a decrease occurs. The pairs of values from the same seasonal period are compared (Crawford and others, 1983; Schertz and Hirsch, 1985; Shertz and others, 1991). In the case where seasons are months, January median values from each year are compared to the previous January median values; February median values from each year are compared to the previous February median values, and so on. If the total number of pluses from the comparison of pairs is greater than the number of minuses, an increasing trend is indicated. Conversely, if more minuses occur than pluses, a decreasing trend is indicated. Depending on the frequency of data collection, the seasonal period can be greater than a month. The use of the median by the Seasonal Kendall test reduces the effect of outliers and provides some protection against serial correlation in the data (Schertz and Hirsch, 1985). A significance level (alpha) of 0.05 was considered to show statistical significance of the trend test. Multiple time periods were examined for trends for each site to identify all possible monotonic trends.

Statistical tests for trends in water quality over time were performed using S-ESTREND version 1.1, which is a "USGS plug-in" version of ESTREND in S-PLUS (version 6.1), a PC-based statistical software package. Documentation is contained in the publicly available USGS library for S-PLUS for Windows, release 2.1 (Slack and others, 2003). ESTREND software can be downloaded from the USGS Web page $h t t p: / /$ water.usgs.gov/software/library.html.

For the trend-test procedure, a minimum of 50 observations over a minimum of 5 years was required. A model using flow-adjusted concentrations was selected for constituents with less than 5-percent censoring (less-than values), only one reporting level, and daily flow data. LOESS flow adjustment and the Seasonal Kendall test for uncensored data were used. This nonparametric test calculates trends on the flow-adjusted concentrations.

A simple five-parameter multiple-regression load model, which includes a time term, with terms for adjustment for flow and season $\ln \mathrm{L}=a_{0}+a_{1} \ln Q+a_{2} t+a_{3} \sin (2 \pi t)+a_{4} \cos$ $(2 \pi t)+e$, was also run for each constituent to provide a test 
of time trend over the period of record. A time term significance level of less than or equal to 0.05 was considered to show a statistically significant trend for the period of record. This alternate approach to testing for trend is included for comparison in the description of the Seasonal Kendall trend results.

\section{Trends in Water-Quality Data}

Data tested for time trends included specific conductance, dissolved oxygen, dissolved ammonia nitrogen, total ammonia and organic nitrogen, dissolved nitrite plus nitrate, total nitrogen, dissolved orthophosphate, total phosphorus, and suspended-sediment concentrations. Trend analysis was conducted on six sites: Little River (site 4T), Mountain Creek (site 6T), Little River tributary (site 8T), Little River below Little River tributary (site 10TA), Flat River (site 5T), and Flat River tributary (site 1T). No significant time trends in any constituent were detected for the Little River site (site 4T). No significant trends were detected for dissolved oxygen, dissolved ammonia nitrogen, dissolved orthophosphate, or total phosphorus at any site. Only results for trend tests that used flow adjustment of constituent concentrations are reported.

The Oblinger and others (2002) study used the Seasonal Kendal method to test for trends at Flat River (site 5T), Flat River tributary (site 1T), and Mountain Creek (site 6T) for the 1988-98 study period. Downward trends in total nitrogen, ammonia plus organic nitrogen, and organic nitrogen were detected for the Flat River tributary, suggesting a small reduction in organic nitrogen over time at this site.

\section{Mountain Creek (Site 6T)}

A statistically significant increasing trend in total nitrogen concentration (1993-2009) was detected for Mountain Creek (site 6T). A graph of the total nitrogen concentrations (fig. 23) over time shows a step decline in total nitrogen prior to 1993, with a slight increase in concentration after 1993. The time term of the five-parameter multiple regression model of the complete 1988-2009 period of record showed no statistical significance.

A statistically significant increasing trend in suspendedsediment concentration was detected for the 1996-2009 period for Mountain Creek (fig. 24). The regression model of the longer 1988-2009 data showed no statistical significance for sediment. The trend may reflect effects of increased residential development in the basin during the 1996-2009 part of the study period.

\section{Little River Tributary (Site 8T)}

A statistically significant increasing trend in specific conductance (1996-2009) was detected for Little River tributary (fig. 25). Regression was not run for specific conductance because load analysis for specific conductance is not appropriate. No other trends were evident for this site.

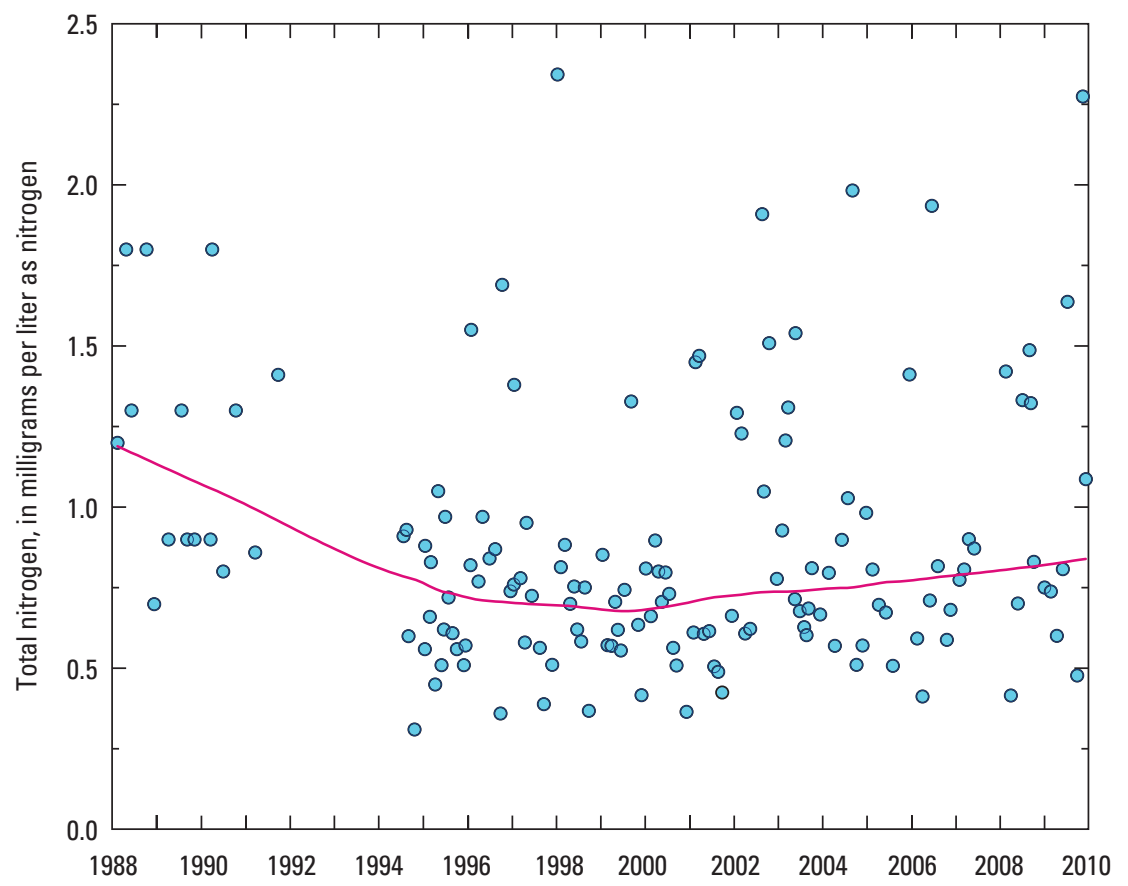

Figure 23. Total nitrogen concentrations with LOESS smooth trend line for Mountain Creek (site 6T), 1988-2009, in the vicinity of the Treyburn development study area, North Carolina. 


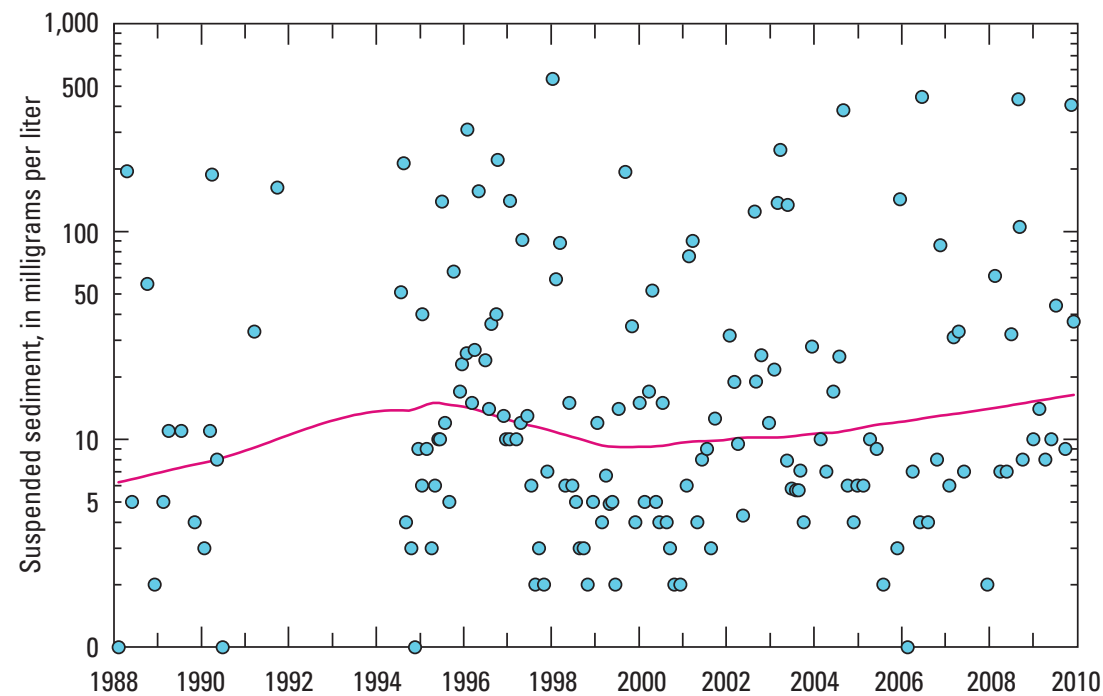

Figure 24. Suspended-sediment concentrations with LOESS smooth trend line for Mountain Creek (site 6T), 1988-2009, in the vicinity of the Treyburn development study area, North Carolina.

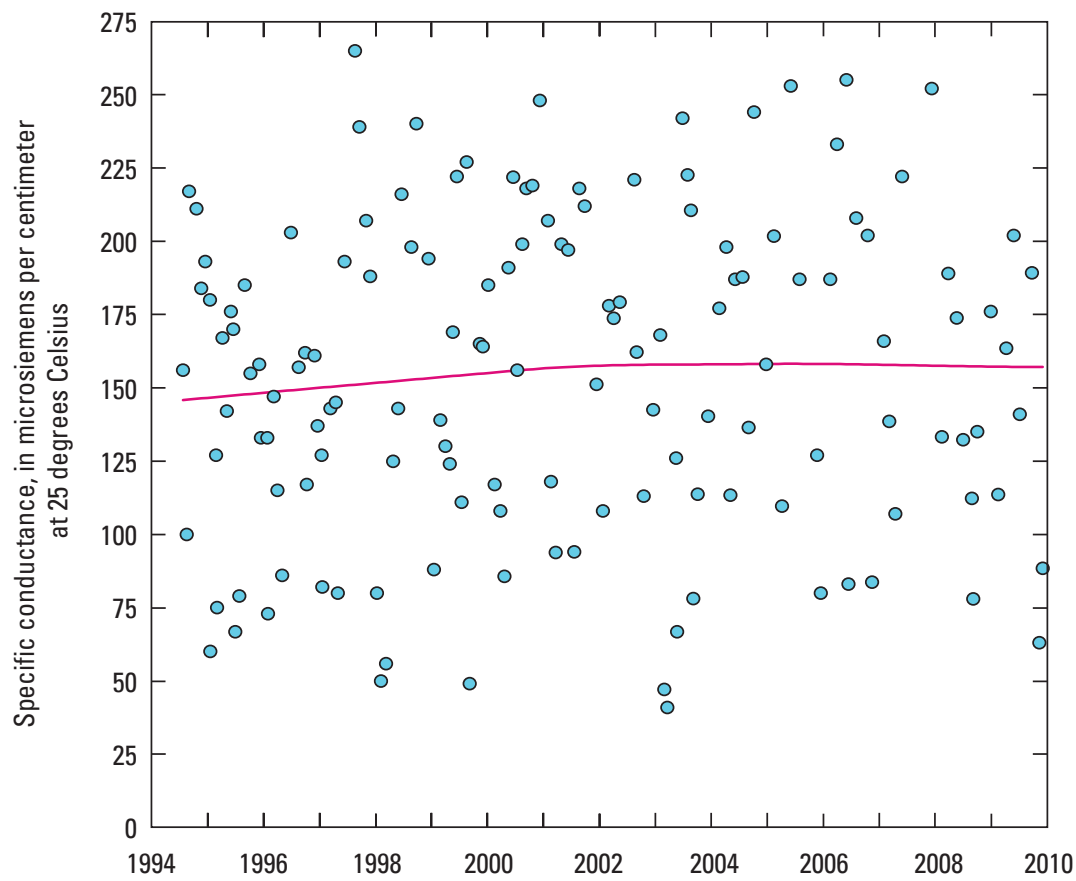

Figure 25. Specific conductance with LOESS smooth trend line for Little River tributary (site 8T), 1994-2009, in the vicinity of the Treyburn development study area, North Carolina. 


\section{Little River Below Little River Tributary (Site 10TA)}

Statistically significant increasing trends in dissolved nitrate (1996-2009, fig. 26) and dissolved nitrite plus nitrate (1996-2009, fig. 27) were detected for Little River below Little River tributary with the Seasonal Kendal test. The fiveparameter regression model of the 1996-2009 data showed no statistical significance of the time term for either nutrient. The reason for this lack of concurrence may be due to an inadequate regression model fit or incomplete data transformation to meet model assumptions. Nonparametric (Seasonal Kendall) techniques do not require data transformation. The regression model showed significant increasing trends for total ammonia plus organic nitrogen (1995-2009, fig. 28) and total nitrogen (1995-2009, fig. 29); however, the Seasonal Kendall test did not detect these long-term trends. A trend that is detected by both methods is more likely to reflect a true trend. Although the different trend test approaches do not produce the same results, one test or the other indicated increasing trends for all the measured nitrogen species at the Little River, suggesting that an increase in nitrogen over time has occurred.

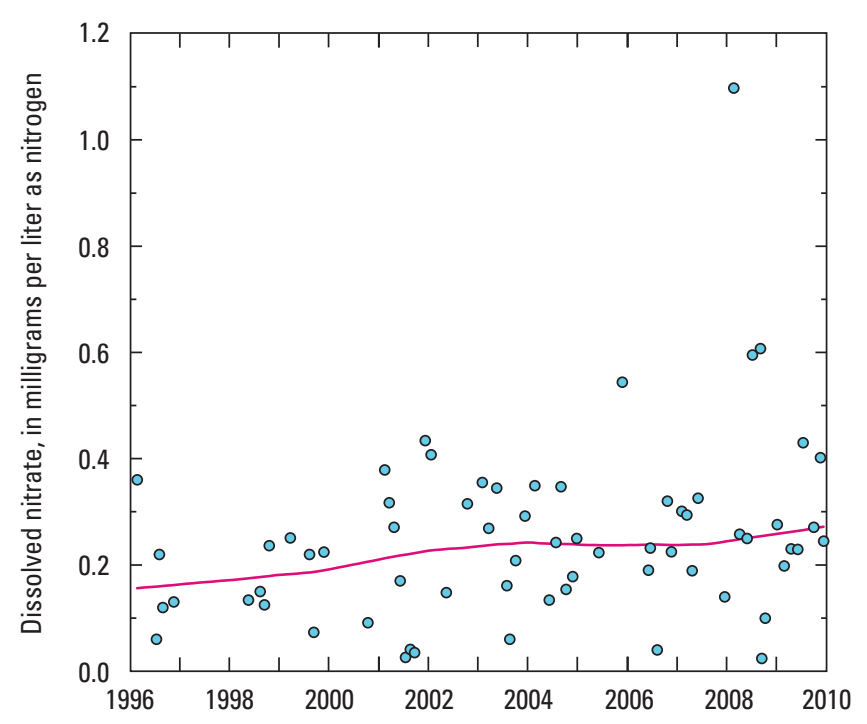

Figure 26. Dissolved nitrate concentration with LOESS smooth trend line for Little River below Little River tributary (site 10TA), 1996-2009, in the vicinity of the Treyburn development study area, North Carolina.

\section{Flat River (Site 5T)}

The regression model showed a significant decreasing trend for dissolved nitrite plus nitrate nitrogen (1994-2009, fig. 30), which was not detected by the seasonal Kendall test. The seasonal Kendall test detected a significant decreasing trend in total ammonia and organic nitrogen for 1993-2009 (fig. 31); however, the regression showed no significant trend for the long-term period of record (1988-2009). Both tests detected a decreasing 1988-2009 sediment trend for the Flat River (fig. 32).

\section{Flat River Tributary (Site 1T)}

A statistically significant decreasing trend in specific conductance (1988-2009) was detected for Flat River tributary (fig. 33). Regression was not run for specific conductance. No other trends were evident for this site.

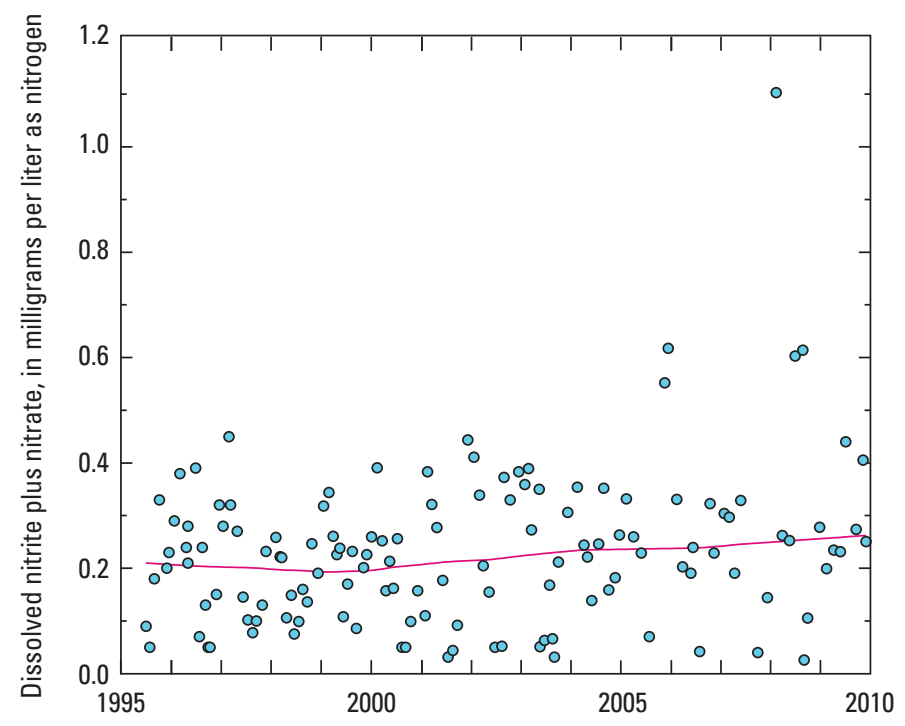

Figure 27. Dissolved nitrite plus nitrate concentration with LOESS smooth trend line for Little River below Little River tributary (site 10TA), 1996-2009, in the vicinity of the Treyburn development study area, North Carolina. 


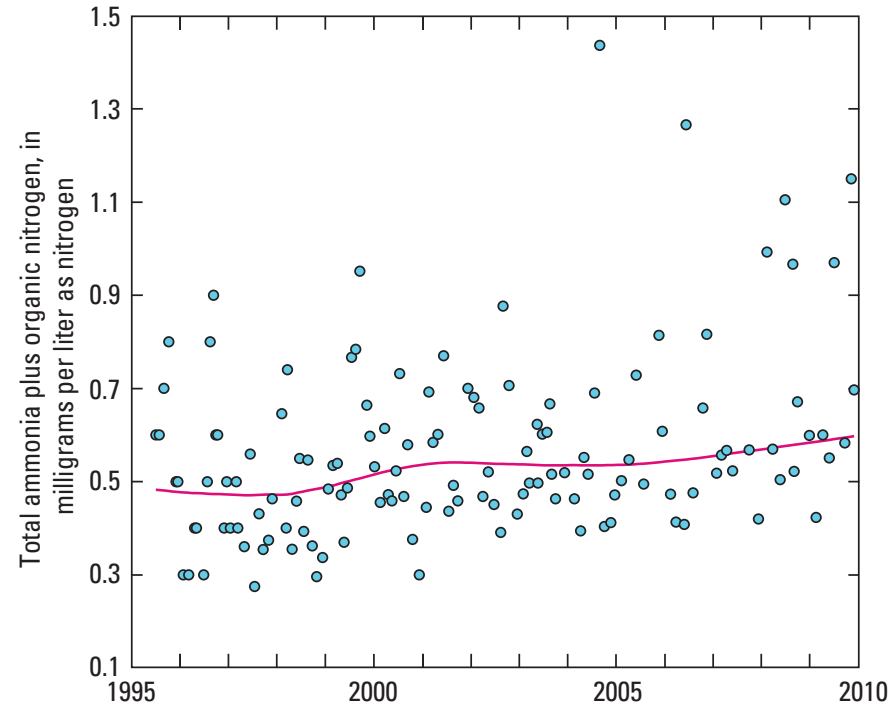

Figure 28. Total ammonia plus organic nitrogen concentration with LOESS smooth trend line for Little River below Little River tributary (site 10TA), 1996-2009, in the vicinity of the Treyburn development study area, North Carolina.

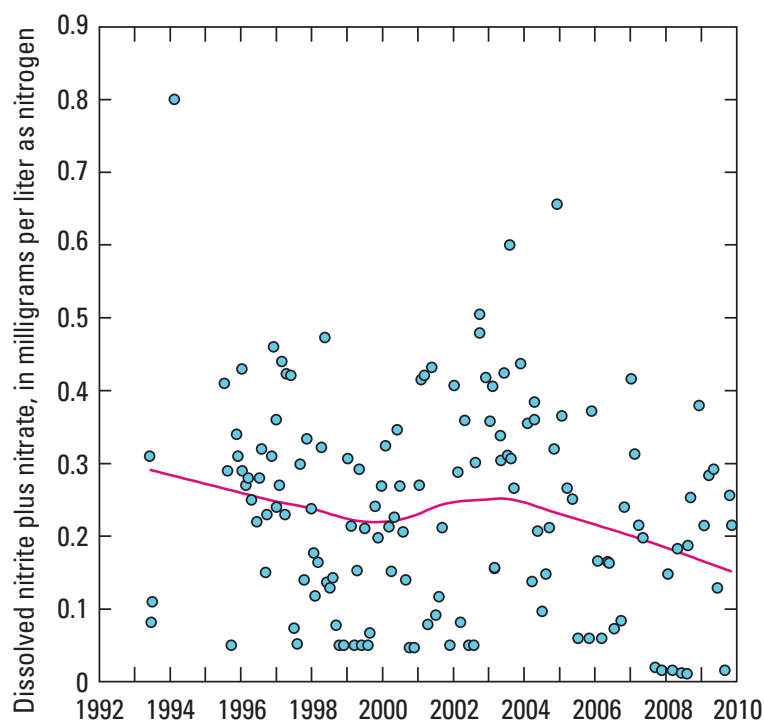

Figure 30. Dissolved nitrite plus nitrate concentration with LOESS smooth trend line for Flat River (site 5T), 1994-2009, in the vicinity of the Treyburn development study area, North Carolina.

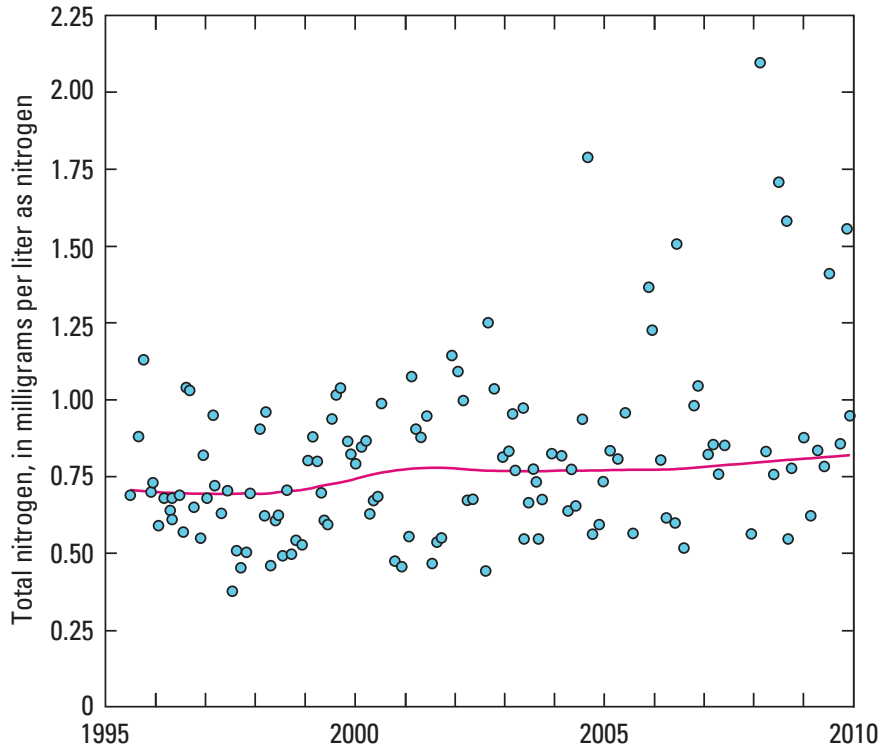

Figure 29. Total nitrogen concentration with LOESS smooth trend line for Little River below Little River tributary (site 10TA), 1996-2009, in the vicinity of the Treyburn development study area, North Carolina.

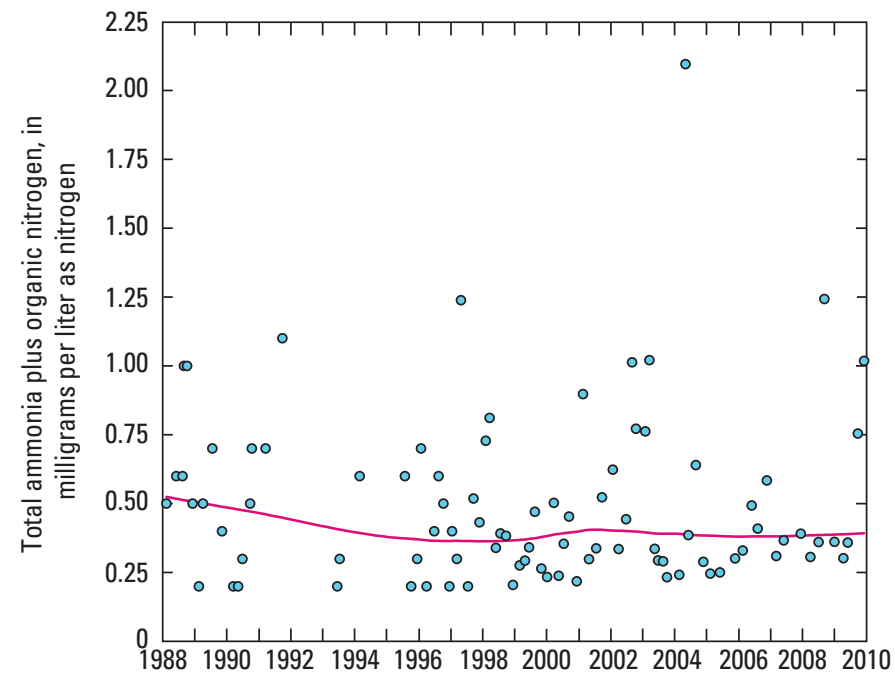

Figure 31. Total ammonia plus organic nitrogen concentration with LOESS smooth trend line for Flat River (site 5T), 1988-2009, in the vicinity of the Treyburn development study area, North Carolina. 


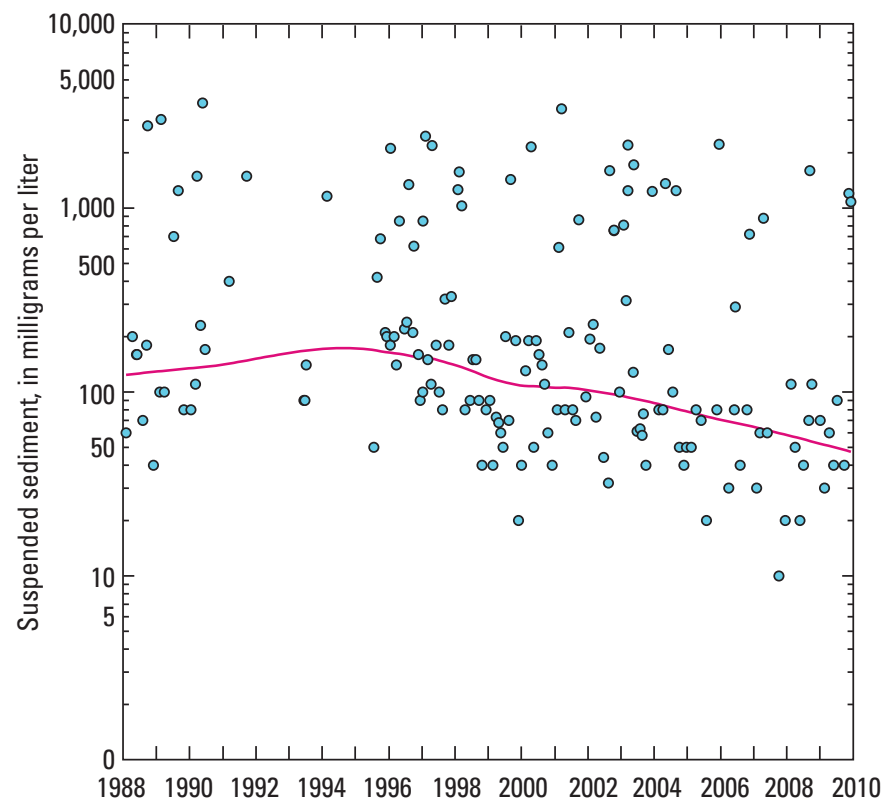

Figure 32. Suspended-sediment concentration with LOESS smooth trend line for Flat River (site 5T), 1988-2009, in the vicinity of the Treyburn development study area, North Carolina.

\section{Summary}

Temporal distributions of water-quality characteristics of streams in the Treyburn development study area indicated only small-scale changes in water quality during the 1988-2009 period-of-record study that might be related to landscape changes. Evaluation of loads, yields, and trends for nutrients and suspended sediment indicated variability with respect to streamflow conditions during the study period. Streamflow and water-quality data for this study were collected from October 1988 through September 2009 at five sites in the Treyburn study area and water-quality samples were collected from an additional site without continuous flow measurement. Water-quality data collected included physical water-quality characteristics and concentrations of nutrients, metals, and pesticides.

Higher than average streamflow occurred during 2003. Streamflow during 2000, 2004, and 2005 was near the long-term mean. Average or lower than average streamflow occurred during most of the remaining years.

The lowest median value of specific conductance for the study sites occurred at the Flat River tributary (site 1T), the least developed of the study sites. The highest median value occurred at the Little River tributary (site $8 \mathrm{~T}$ ), the most developed site. Higher median specific conductance noted for the Little River below Little River tributary (site 10TA) and Mountain Creek (site 6T) may be due to development within these basins.

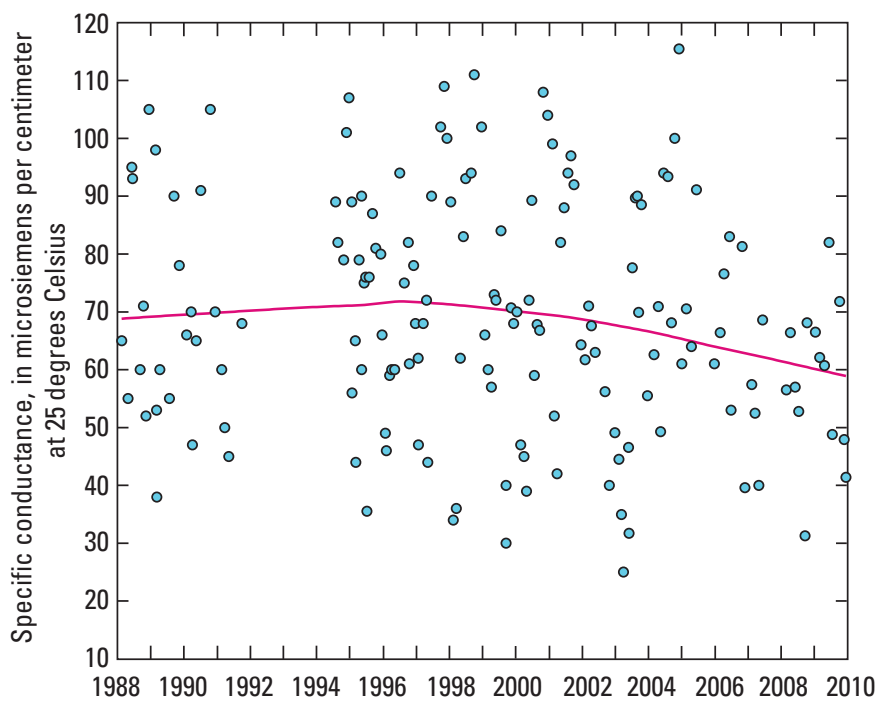

Figure 33. Specific conductance with LOESS smooth trend line for Flat River tributary (site 1T), 1988-2009, in the vicinity of the Treyburn development study area, North Carolina.

Median $\mathrm{pH}$ for the Flat River tributary (site 1T) was significantly lower than for the other sites. No significant differences in median suspended-sediment concentration were noted among the sites. Iron and manganese were frequently detected over the 1987-2009 study period at all sites at concentrations greater than water-quality criterion levels. The frequency of detection of the other sampled metals at all sites is generally low, not usually exceeding laboratory reporting levels or criterion levels.

The smallest median nutrient concentrations occurred in the Flat River tributary (site 1T), which represents more undeveloped watershed conditions. The median values of the different nitrogen species at the Treyburn sites all fell within previously published background concentration ranges for the Piedmont Province in North Carolina. Phosphorus and nitrogen concentrations for the Treyburn sites are low compared to sites nationally.

Little River below Little River tributary (site 10TA) had the greatest number and frequency of pesticides detected and generally the highest concentrations. Four herbicides (atrazine, metolachlor, prometon, and simazine) were frequently detected at Mountain Creek (site 6T) and Little River tributary (site $8 \mathrm{~T}$ ). Three herbicides (atrazine, metolachlor, and alachlor) were detected at the Flat River tributary (site 1T). Herbicide concentrations at these sites were low compared to sites nationally.

Seasonality in constituent concentrations was apparent in the study sites. Little River below Little River tributary 
(site 10TA), Mountain Creek (site 6T), Flat River (site 5T), and Eno River (site 11T) showed low suspended-sediment concentrations in June and July and January and December, with higher concentrations during the spring and fall. Dissolved-oxygen concentrations are highest in February and are lowest in July and August. Total nitrogen concentrations at Little River (4T) and Flat River (site 5T) are generally lowest during June through August. Nitrogen concentrations are higher from December through March at Mountain Creek (site 6T) and Little River below Little River tributary (site 8T). Few distinct seasonal patterns were apparent in phosphorus concentrations at the study sites.

Annual suspended-sediment loads and yields for the study sites showed considerable basin-to-basin and year-toyear variation. Flow data measured over the 1988-2009 period of record were used to generate load and yield estimates. The highest loads and yields for all sites occurred during water years 1996 or 2003 .

Little River below Little River tributary (site 10TA) had the lowest median suspended-sediment yield over the study period, and Flat River tributary (site 1T) had the largest median yield during the study period. The yields estimated for the study sites are low compared to suspended-sediment yields estimated for other basins in the Southeastern United States. The nitrogen and phosphorus yields estimated for the study sites are also low compared to nitrogen yields estimated for other basins in the Southeast.

Statistically significant increasing trends in total nitrogen concentration (1993-2009) and suspended-sediment concentrations (1996-2009) were detected for Mountain Creek (site 6T). A statistically significant increasing trend in specific conductance (1996-2009) was detected for Little River tributary (site 8T). Decreasing trends for the Flat River (site 5T) in dissolved nitrite plus nitrate nitrogen (1994-2009) and in total ammonia and organic nitrogen (1993-2009) were indicated. A decreasing 1987-2009 sediment trend for the Flat River (site 5T) and a statistically significant decreasing trend in specific conductance for Flat River tributary (site 1T) were detected. Few trends, however, were detected by both regression and the Seasonal Kendall test, suggesting ambiguity in these results.

Water-chemical concentrations, loads, yields, and trends for the Treyburn study sites reflect some effects of upstream development. These measures of water quality, however, were generally within regional and national averages or considered low compared to those averages.

\section{References Cited}

Bradu, D., and Mundlak, Y., 1970, Estimation in lognormal linear models: Journal of the American Statistical Association, v. 65, p. 198-211.

Britton, L.J., and Greeson, P.E., eds., 1989, Methods for collection and analyses of aquatic biological and microbiological samples: U.S. Geological Survey Techniques of WaterResources Investigations, book 5, chap. A4, 363 p.

Caldwell, W.S., 1992, Selected water-quality and biological characteristics of streams in some forested basins of North Carolina, 1985-88: U.S. Geological Survey WaterResources Investigations Report 92-4129, 114 p.

Childress, C.J.O., and Bathala, Neeti, 1997, Water-quality trends for streams and reservoirs in the Research Triangle area of North Carolina, 1983-95: U.S. Geological Survey Water-Resources Investigations Report 97-4061, 18 p.

Cohn, T.A., 1988, Adjusted maximum likelihood estimation of the moments of lognormal populations from type I censored samples: U.S. Geological Survey Open-File Report 88-350, $34 \mathrm{p}$.

Cohn, T.A., Caulder, D.L., Gilroy, E.J., Zynjul, L.D., and Summers, R.M., 1992, The validity of a simple statistical model for estimating fluvial constituent loads: An empirical study involving nutrient loads entering Chesapeake Bay: Water Resources Research, v. 28, no. 9, p. 2353-2363.

Cohn, T.A., DeLong, L.L., Gilroy, E.J., Hirsch, R.M., and Wells, D.K., 1989, Estimating constituent loads: Water Resources Research, v. 25, no. 5, p. 937-942.

Crawford, C.G., Slack, J.R, and Hirsch, R.M., 1983, Tests for trends in water quality data using the statistical analysis system: U.S. Geological Survey Open-File Report 83-550, $106 \mathrm{p}$.

Edwards, T.K., and Glysson, G.D., 1988, Field methods for measurements of fluvial sediment: U.S. Geological Survey Open-File Report 86-531, 118 p.

Fishman, M.J., ed., 1993, Methods of analysis by the U.S. Geological Survey National Water-Quality LaboratoryDetermination of inorganic and organic constituents in water and fluvial sediments: U.S. Geological Survey Open-File Report 93-125, 217 p. 
Fishman, M.J., and Friedman, L.C., eds., 1989, Methods for determination of inorganic substances in water and fluvial sediments: U.S. Geological Survey Techniques of WaterResources Investigations, book 5, chap. A1, 545 p.

Garrett, R.G., and Bales, J.D., 1995, Water-quality characteristics of streams in the Treyburn development area of Falls Lake watershed, North Carolina, 1988-93: U.S. Geological Survey Water-Resources Investigations Report 95-4094, $79 \mathrm{p}$.

Gilliom, R.J., Barbash, J.E., Crawford, C.G., Hamilton, P.A., Martin, J.D., Nakagaki, Naomi, Nowell, L.H., Scott, J.C., Stackelberg, P.E., Thelin, G.P., and Wolock, D.M., 2007, Pesticides in the Nation's streams and ground water, 1992-2001: U.S. Geological Survey Circular 1291, 173 p.

Gilroy, E.J., Hirsch, R.M., and Cohn, T.A., 1990, Mean square error of regression-based constituent transport estimates: Water Resources Research, v. 26, p. 2069-2077.

Guy, H.P., 1969, Laboratory theory and methods for sediment analyses: U.S. Geological Survey Techniques of WaterResources Investigations, book 5, chap. C1, 58 p.

Harned, D.A., McMahon, Gerard, Spruill, T.B., and Woodside, M.D., 1995, Water-quality assessment of the AlbemarlePamlico drainage basin, North Carolina and VirginiaCharacterization of suspended sediment, nutrients and pesticides: U.S. Geological Survey Open-File Report 95-191, $131 \mathrm{p}$.

Helsel, D.R., 1993, Hydrology of stream water qualityStatistical analysis of water-quality data, in Paulson, R.W., Chase, E.B., Williams, J.S., and Moody, D.W., comps., National water summary 1990-91-Hydrologic events and stream water quality: U.S. Geological Survey Water-Supply Paper 2400, p. 93-100, accessed January 9, 2013, at http:// pubs.er.usgs.gov/usgspubs/wsp/wsp2400.

Hirsch, R.M., Slack, J.R., and Smith, R.A., 1982, Techniques of trend analysis for monthly water quality data: Water Resources Research, v. 18, no. 1, p. 107-121.

Kruskal, W.H., and Wallis, W.A., 1952, Use of ranks in onecriterion variance analysis: Journal of the American Statistical Association, v. 47, no. 260, p. 583-621.

Mueller, D.K., Hamilton, P.A., Helsel, D.R., Hitt, K.J., and Ruddy, B.C., 1995, Nutrients in ground water and surface water of the United States - An analysis of data through 1992: U.S. Geological Survey Water-Resources Investigations Report 95-4031, 74 p.

Mueller, D.S., and Wagner, C.R., 2009, Measuring discharge with acoustic Doppler current profilers from a moving boat: U.S. Geological Survey Techniques and Methods 3A-22, 72 p. (Also available online at http://pubs.water.usgs.gov/ tm3a22.)
National Oceanic and Atmospheric Administration, 1988-2009 [published annually], Climatological data annual summaries - North Carolina: Asheville, N.C., National Climatic Data Center, accessed October 2010 at http://cdo.ncdc.noaa.gov/ancsum/ACS.

North Carolina Department of Environment, Health, and Natural Resources, 1993, Neuse River basinwide water quality management plan: Raleigh, North Carolina Division of Environmental Management [variously paged].

North Carolina Department of Environment and Natural Resources, 2007, "Redbook” Administrative code sections 15A NCAC 2B.0100 - and .0200s; and 15A NCAC 2B.0200 - to Surface waters and wetlands, amended April 1, 2003: Raleigh, North Carolina Division of Water Quality, $130 \mathrm{p}$.

North Carolina Department of Environment and Natural Resources, 2009, Neuse River Basinwide water quality plan: Raleigh, North Carolina Division of Water Quality, accessed September 2012 at http://portal.ncdenr.org/web/ wq/ps/bpu/basin/neuse/2009.

North Carolina Division of Water Quality, 2000, Water quality progress in North Carolina, 1998-99, 305(b) report: Raleigh, North Carolina Department of Environment and Natural Resources.

North Carolina Division of Water Quality, 2011, The Neuse Buffer Rules, accessed October 2010 at http://portal.ncdenr. org/web/wq/cgeninfo.

North Carolina Office of State Budget, Planning and Management, 2009, 2009 municipal population estimates, accessed October 2010 at http://www.osbm.state.nc.us/ncosbm/ facts_and_figures/socioeconomic_data/population_ estimates/demog/muntot09.htm.

Oblinger, C.J., 2004, Triangle Area Water Supply Monitoring Project, October 1988 through September 2001, North Carolina-Description of the water-quality network, sampling and analysis methods, and quality-assurance practices: U.S. Geological Survey Open-File Report 2004-1278, 56 p.

Oblinger, C.J., Cuffney, T.F., Meador, M.R., and Garrett, R.G., 2002, Water-quality and physical characteristics of streams in the Treyburn development area of Falls Lake watershed, North Carolina, 1994-98: U.S. Geological Survey WaterResources Investigations Report 02-4046, 80 p., accessed January 9, 2013, at http://nc.water.usgs.gov/reports/ abstracts/wri024046.html.

Rantz, S.E., and others, 1982, Measurement and computation of streamflow: U.S. Geological Survey Water-Supply Paper $2175,631 \mathrm{p}$.

Reid, J.C., 1993, A geochemical atlas of North Carolina: North Carolina Geological Survey, Bulletin 93, 48 p. 
Runkel, R.L., Crawford, C.G., and Cohn, T.A., 2004, Load Estimator (LOADEST)-A FORTRAN program for estimating constituent loads in streams and rivers: U.S. Geological Survey Techniques and Methods, book 4, chap. A5, 69 p.

Sauer, V.B., and Turnipseed, D.P., 2010, Stage measurements at gaging stations: U.S. Geological Survey Techniques and Methods, book 3, chap. A7, 45 p.

Schertz, T.L., Alexander, R.B., and Ohe, D.J., 1991, The computer program estimate trend (ESTREND), a system for the detection of trends in water-quality data: U.S. Geological Survey Water-Resources Investigations Report 91-4040, $68 \mathrm{p}$.

Schertz, T.L., and Hirsch, R.M., 1985, Trend analysis of weekly acid rain data, 1978-83: U.S. Geological Survey Water-Resources Investigations Report 85-4211, 64 p.

Simmons, C.E., and Heath, R.C., 1982, Water quality characteristics of streams in forested and rural areas of North Carolina, in Water quality of North Carolina: U.S. Geological Survey Water-Supply Paper 2185-B, p. B1-B33.

Slack, J.R., Lorenz, D.L., and others, 2003, USGS library for S-PLUS for Windows, Release 2: U.S. Geological Survey Open-File Report 2003-357, accessed December 2007 at http://pubs.er.usgs.gov/usgspubs/ofr/ofro3357 [release 2.1 was available in January 2008 at http://water.usgs.gov/ software/S-PLUS/].

Staub, E.L., Peak, K.L., Tighe, K.C., Sadorf, E.M., and Harned, D.A., 2010, Data used in analyses of trends, and nutrient and suspended-sediment loads for streams in the Southeastern United States, 1973-2005: U.S. Geological Survey Data Series 488. (Also available at $h t t p: / / p u b s . u s g s$. gov/ds/488/.)

Tukey, J.W., 1977, Exploratory data analysis: Reading, Massachusetts, Addison-Wesley Publishing, 506 p.

U.S. Department of Agriculture, 1976, Soil survey of Durham County, North Carolina: U.S. Department of Agriculture, Soil Conservation Service, $74 \mathrm{p}$.

U.S. Geological Survey, variously dated, National field manual for the collection of water-quality data: U.S. Geological Survey Techniques of Water-Resources Investigations, book 9, chaps. A1-A9. (Also available online at http://pubs. water.usgs.gov/twri9A/.)

U.S. Geological Survey, 2007, Facing tomorrow's challenges-U.S. Geological Survey science in the decade 2007-2017: U.S. Geological Survey Circular 1309, 70 p.

Ward, J.R., and Harr, C.A., eds., 1990, Methods for collection and processing of surface-water and bed-material samples for physical and chemical analyses: U.S. Geological Survey Open-File Report 90-140, 71 p.
Weaver, J.C., 2005, The drought of 1998-2002 in North Carolina-Precipitation and hydrologic conditions: U.S. Geological Survey Water-Resources Investigations Report 2005-5053, 98 p.

Wershaw, R.L., Fishman, M.J., Grabbe, R.R., and Lowe, L.E., 1987, Methods for the determination of organic substances in water and fluvial sediments: U.S. Geological Survey Techniques of Water-Resources Investigations, book 5, chap. A3, 80 p.

Zaugg, S.D., Sandstrom, M.W., Smith, S.G., and Fehlberg, K.M., 1995, Methods of analysis by the U.S. Geological Survey National Water Quality Laboratory-Determination of pesticides in water by C-18 solid-phase extraction and capillary-column gas chromatography/mass spectrometry with selected-ion monitoring: U.S. Geological Survey Open-File Report 95-181, 60 p. 
Prepared by:

USGS Science Publishing Network

Raleigh Publishing Service Center

3916 Sunset Ridge Road

Raleigh, NC 27607

USGS Publishing Service Center staff:

Kay Naugle, Editor

Jeffery L. Corbett, Illustrator

Gregory L. Simpson, layout

For additional information regarding this publication, contact:

Director

USGS North Carolina Water Science Center

3916 Sunset Ridge Road

Raleigh, NC 27607

email: dc_nc@usgs.gov

Or visit USGS North Carolina Water Science Center at:

http://nc.water.usgs.gov/ 
